\title{
O USO DO TEMPO E O FAZER DIÁRIO DE MULHERES IDOSAS
}

\section{LEONICE APARECIDA DOIMO}

Tese apresentada ao Departamento de Prática de Saúde da Faculdade de Saúde Pública da Universidade de São Paulo para obtenção do grau de Doutor em Saúde Pública.

ORIENTADORA: PROFA. DRA. ALICE MOREIRA DERNTL 
Uma das mais lindas compensaçöes desta vida é que ninguém poderá sinceramente tentar ajudar outra pessoa sem ajudar a si mesmo

\section{Emerson}




\section{DEDICATÓRIA}

Á Luiza, minha mãe

Á Angela, irmã e pessoa simplesmente maravilhosa

Á Wilma, in memorian, por transmitir-me os melhores valores da existência humana

A João, meu querido pai, in memorian, por ter amado seus filhos 


\section{AGRADECIMENTOS}

À Profa. Dra. Alice Moreira Derntl, pela orientação, confiança e, principalmente, pelo carinho dedicado ao longo da realização deste trabalho.

$\dot{A}$ todas as senhoras que gentilmente e prontamente cederam um pouco do seu tempo, concordando em participar desta pesquisa.

À coordenadora do grupo de convivência de Rio Claro, Sra. Maria Cerri Cive, pela solicitude, carinho e, principalmente, por ensinar-me o caminho da espiritualidade.

Ao amigo Olival do Lago, por toda ajuda e constante solicitude na elaboração dos resultados.

A Paulo e Izabel, por serem apoio e presença incondicionais em qualquer instante.

A Armando, Pina e Matheus, pelos incontáveis finais de semana que lhes roubei.

Á "Tia Rita" (Rita Assad), pelo carinho e por ensinar, através de suas atitudes, o verdadeiro exercício do profissionalismo.

Aos amigos do Esporte Clube Pinheiros, em especial à Flávia, Fernando, Maurício, Albertinho, Alberto, Taba, Adriana, Ari, Marta, Valéria, Eliana, Patrícia, Regina, Johnny, Luzia, Reinaldo, Beto, Claudinha, Fábio, Gilberto, Cláudio e Alexandre, pelos vários anos partilhados.

Aos muitos amigos, visíveis e invisíveis, que, em hora oportuna, sempre incentivaram a conquista de novos horizontes. 


\section{RESUMO}

Doimo, L. A . O uso do tempo e o fazer diário de mulheres idosas. São Paulo, 2002. [Tese de Doutorado - Faculdade de Saúde Pública da Universidade de São Paulo - USP].

A maioria do conhecimento sobre atividades diárias de idosos resulta de estudos da área de geriatria, principalmente sobre atividades básicas da vida diária e atividades instrumentais da vida diária com o objetivo de se determinar a necessidade de assistência e de intervenção quando o desempenho torna-se insuficiente para uma vida independente. Objetivo: descrever o uso do tempo em um grupo de mulheres idosas, com base nas atividades diárias, avaliadas entre o acordar e o adormecer. Método: estudo descritivo das atividades diárias de 25 mulheres idosas, com 60 anos e mais, pertencentes a um grupo de convivència da cidade de Rio Claro. Foi feita a seleção da amostra de conveniência através da aplicação de um teste de cognição (Clock Completion Test). Utilizou-se também um instrumento para obtenção de dados pessoais e uma entrevista estruturada ("Time Diary") para obter o relato das atividades feitas no dia anterior à entrevista. A decodificação e classificação das atividades diárias foram feitas através de uma classificação internacional (Austrália) para estudos de uso do tempo, obtendo-se os perfis das atividades diárias distribuidos em nove grupos de atividades principais bem como seus contextos físico e social. Resultados: o grupo realizou na maior parte do tempo atividades obrigatórias, distribuidas em atividades domésticas e atividades de cuidados pessoais. A maior parte do tempo livre foi alocado com lazer passivo (assistir televisão). A casa foi o local onde se realizou a maioria das atividades (contexto físico), estando as idosas, na maior parte do tempo com membros da própria familia ou sozinhas (contexto social). A maioria do grupo possui baixa renda e escolaridade e algumas idosas exercem atividades remuneradas porém sem registro. Provavelmente houve influência de fatores individuais como idade, gênero, grau de instrução, estado civil e nivel sócioeconômico sobre os padrões encontrados para o uso do tempo.

Descritores: Envelhecimento. Idoso. Competência diária. Uso do tempo. 


\section{ABSTRACT}

Doimo, L. A . Time use and daily affairs of elderly women. São Paulo, 2002.[Doctorate Thesis - Faculdade de Saúde Pública da Universidade de São Paulo - USP].

Most of the knowledge of the daily activities of the elderly arises from the geriatric area studies, particularly on basic activities of daily life and instrumental activities of daily life aiming to determine the need for care and intervention when performance becomes insufficient for an independent life. Objective: to describe time use within a group of elderly women, based on daily activities, evaluated between waking up and going to sleep. Method: descriptive study on the daily activities of 25 elderly women, aged 60 years and over, belonging to a companionship group in the city of Rio Claro. A cognition test (Clock Completion Test) was used for convenience sample selection. Furthermore, personal data were obtained through a form and a structured interview ("Time Diary") was used for the report on the activities carried out on the day prior to the interview to be obtained. Daily activities decoding and classification were performed by means of an international classification (Australia) for time use studies, thus obtaining the profiles of the daily activities assigned to nine main activities groups as well as their physical and social contexts. Results: the group most of the time performed mandatory activities, split into domestic and personal care activities. Most of the free time was spent in passive pleasure (TV watching). The house was the site where most of the activities were performed (physical context), with the elderly women being, most of the time, either with members of their own family or alone (social context). The majority in the group has a low income and educational level and some of them have remunerated activities albeit without registration. Most likely individual factors such as age, gender, level of education, marital status and socioeconomic level played a role in the time use patterns found.

Descriptors: Aging. Elderly. Daily Competence. Time Use. 


\section{LISTA DE TABELAS}

TABELA 1 - Distribuição da amostra segundo número, média e desvio padrão por faixa etária (anos)

TABELA 2 - Distribuição do número e porcentagens de idosas segundo estado civil e escolaridade (em anos de estudo)

TABELA 3 - Distribuição do número e porcentagens de idosas segundo renda (em salários minimos)

TABELA 4 - Distribuição do número e porcentagens de idosas segundo ocupação doméstica (do lar) e trabalho (remunerado) antes e após 60 anos

TABELA 5 - Distribuição do número e porcentagens de pessoas 73 residentes no domicilio

TABELA 6 - Distribuição dos grupos principais de atividades (valores absolutos, minutos e percentuais) em relação ao dia efetivo

TABELA 7 - Distribuição dos tipos de atividades remuneradas (valores absolutos, minutos e percentuais)

TABELA 8 - Distribuição das atividades de lazer e recreação (valores absolutos, minutos e percentuais)

TABELA 9 - Distribuição das atividades secundárias (valores absolutos, minutos e percentuais)

TABELA 10 - Contextos fisicos das atividades principais (valores absolutos, minutos e percentuais)

TABELA 11 - Contextos sociais das atividades principais (valores absolutos, minutos e percentuais) 


\section{LISTA DE FIGURAS}

FIGURA 1 - Distribuição percentual dos grupos de atividades principais em relação ao dia efetivo

FIGURA 2 - Distribuição percentual das atividades de trabalho remunerado

FIGURA 3 - Distribuição percentual das atividades de lazer e recreação

FIGURA 4 - Distribuição percentual das atividades secundárias

FIGURA 5 - Distribuição percentual do contexto físico dos grupos de atividades principais

FIGURA 6 - Distribuição percentual do contexto social dos grupos de atividades principais 


\section{ÍNDICE}

1 TNTRODUÇÃO 1

2 JUSTIFICATIVA

3 REVISÃO DE LITERATURA 9

3.1 Origem e importância dos estudos sobre uso do tempo 9

$\begin{array}{ll}3.2 \text { Utilização dos dados sobre uso do tempo } & 13\end{array}$

3.3 Classificações internacionais para estudos de uso do tempo $\quad 14$

3.4 Conceitos de competência diária $\quad 19$

$\begin{array}{ll}3.5 \text { Conceitos de autonomia e independência } & 27\end{array}$

3.6 Modelos de competência 33

3.7 Tempo e estruturação da vida diária 35

3.8 Estudos sobre uso do tempo com população idosa

$\begin{array}{ll}3.9 \text { Estilo de vida } & 48\end{array}$

3.10 A feminização do envelhecimento - breves considerações 52

4 OBJETIVO

5 MÉTODO 58

$\begin{array}{ll}5.1 \text { Tipo de pesquisa } & 58\end{array}$

5.2 População e amostra $\quad 58$

5.3 Critério de participação $\quad 59$

$\begin{array}{ll}5.4 \text { Coleta de dados } & 60\end{array}$

5.4.1 Descrição do Clock Completion Test 61

5.4.2 Modo de interpretação do Clock Completion Test 62

5.4.3 Registro de dados pessoais $\quad 62$

5.4.4 Time Diary 63

5.5 Análise e interpretação dos dados $\quad 64$

5.5.1 Clock Completion Test $\quad 64$

5.5.2 Time Diary 65

5.5.3 Classificação das atividades de uso do tempo (Time Use $\begin{array}{ll}\text { Activity Classification) } & 66\end{array}$ 
5.5.4 Atividades secundárias, contextos físico e social, tipo de trabalho e lazer $\quad 66$

$\begin{array}{ll}5.6 \text { Tratamento estatístico } & 68\end{array}$

6 RESULTADOS $\quad 70$

7 DISCUSSÃO 84

8 CONCLUSÕES 106

9 RECOMENDAÇÕES 107

$\begin{array}{ll}10 \text { REFERÊNCIAS BIBLIOGRÁFICAS } & 110\end{array}$

ANEXOS

$\begin{array}{ll}\text { I Termo de Consentimento para participação em pesquisa } & 127\end{array}$

$\begin{array}{lr}\text { II - Clock Completion Test } & 128\end{array}$

$\begin{array}{ll}\text { III - Resultados do Clock Completion Test } & 129\end{array}$

$\begin{array}{ll}\text { IV - Folha de registro de dados pessoais } & 130\end{array}$

V - Time Diary 131

$\begin{array}{lr}\text { VI - Time Diary (português) } & 132\end{array}$

VII - Classificação das atividades de uso do tempo (Time Use Activity 133

Classification)

VIII - Fluxograma das atividades dos grupos principais de atividades $\quad 144$

$\begin{array}{ll}\text { IX - Parecer do Comitê de Ética em Pesquisa } & 147\end{array}$ 


\section{INTRODUÇÃO}

O envelhecimento populacional atualmente se constitui num dos fenômenos mundiais que vem recebendo atenção de inúmeros segmentos, em virtude das amplas implicações de ordem econômica e social que impõe às diferentes sociedades.

A população idosa vem aumentando em número e em proporção, especialmente na América Latina, fazendo com que as necessidades de saúde e recursos sociais exigidos por esta parcela de indivíduos tornem-se cada vez mais aparentes (ALVAREZ \& MERING, 1989; CHECKOWAY, 1994).

Projeções demográficas indicam que o aumento da população idosa ocorrerá mais intensamente em paises do terceiro mundo sendo também este grupo que mais crescerá em países com esta característica de desenvolvimento (KALACHE et al. 1987).

Para o Brasil, estima-se que o crescimento da população idosa será de 16 vezes no periodo entre 1950 e 2025 enquanto que o da população como um todo não será maior que cinco vezes no mesmo período. Isso fará do pais o possuidor da sexta população de idosos no mundo, em termos absolutos (WHO, 1989).

O aumento deste grupo é resultado do aumento da expectativa de vida ao nascer e da redução das taxas de natalidade e mortalidade infantil, aspectos presentes em graus variados em todos os países (BERQUÓ 1996; CHAIMOWICZ, 1997).

Um aspecto relevante diz respeito à feminização do envelhecimento pois, em muitos paises, mulheres são a maioria da população idosa e esta proporção aumenta com o avanço da idade (WHO, 1999). O fenômeno da longevidade, ao mesmo tempo que é um indicador da melhor qualidade de vida deste grupo, torna-se um de seus maiores problemas na medida que o expõe, de forma mais acentuada, aos mecanismos de debilitação biológica devido à alta incidência de doenças crônicas e incapacitantes (GOLDANI, 1999). 
As perspectivas para o terceiro milênio englobam adotar medidas preventivas para que a grande maioria das pessoas idosas possa desfrutar a velhice com as melhores condições de saúde e bem estar, ou seja, pessoas autônomas em relação ás suas capacidades física, psicológica, social, econômica e afetiva, condições estas essenciais para um envelhecimento bem sucedido (SAYEG, 1998).

Ao se considerar a saúde da pessoa idosa, é imperativo ter em mente suas relações com a sociedade pois, num sentido mais amplo, saúde é a soma das condições de alimentação, habitação, educação, renda, meio ambiente, trabalho, transporte, emprego, lazer, liberdade, acesso e posse da terra e acesso a serviços de saúde (PACHECO, 1997).

A velhice é uma etapa do desenvolvimento que requer tratamento diferenciado pois, do ponto de vista social, psíquico e físico, pessoas idosas são, caracteristicamente, mais heterogêneas que grupos etários mais jovens. Promover saúde nesta população implica em diagnóstico e estabelecimento de ações e meios para implementar os aspectos social, mental e físico destes indivíduos, bem como prevenir e retardar enfermidades e disfunções que se apresentam de forma mais prevalente nesta população (OPS, 1994).

$\mathrm{Na}$ atualidade, as políticas voltadas à saúde do idoso preconizam mantê-lo na sociedade o maior tempo possivel com autonomia e independência, dois importantes indicadores de saúde para esta população (PNSI, 1996). Para tanto, apoiam-se num novo paradigma, o da Promoção da Saúde, que traz como uma de suas estratégias a prática do autocuidado. Este conceito, geralmente simplificado e traduzido em escalas de atividades básicas da vida diária, deveria ser ampliado para o cotidiano do idoso pois, numa visão mais abrangente, o conjunto de hábitos, comportamentos e ações externalizados pelo idoso no seu dia-a-dia refletem o cuidado que dispensa a si próprio, sendo este cuidar fruto da interação multifatorial com o meio em que vive e também uma expressão de sua autonomia. 
Hoje, observa-se um grande número de pessoas envelhecendo precariamente, vítimas de inúmeras vicissitudes, quer do ponto de vista genético, ambiental, econômico e comportamental. Tais individuos são portadores de uma ou mais patologias crônicas e seqüelas as quais limitam ou extinguem completamente a independência e autonomia tornando-os incapacitados. Idoso incapacitado significa idoso dependente que necessitará de cuidados de longa duração, freqüentemente implicando em intervenções custosas (PASCHOAL, 1997).

Dentre as várias linhas de pesquisa da gerontologia que objetivam melhor compreender do fenômeno do envelhecimento, destaca-se o estudo da competência da pessoa idosa, com ênfase em algumas áreas relevantes de estudo: a) processos cognitivos, b) atividades da vida diária (AVD's) e atividades instrumentais da vida diária (AIVD's), c) enfrentamento de problemas, d) gerontologia ecológica e e) uso do tempo (ou orçamento do tempo) (WAHL, 1998).

O conhecimento produzido por cada uma dessas áreas de estudo pode mostrar os meios ou levar à adoção de medidas através das quais idosos e as novas coortes que estão envelhecendo possam desfrutar a vida da melhor maneira possível (GIGER et al., 1998). Pretende-se assim, saber como manter o bem estar em todos os estágios da velhice, mesmo na presença de deficiências ou incapacidades, especialmente quando se considera o bem-estar como uma junção de vários fatores.

Esta perspectiva multifatorial é baseada na constatação de que os estados físico, psicológico, social, cultural, mental e espiritual interagem, influenciando diretamente o estado de bem-estar e que a pessoa idosa não é um agente passivo mas parte ativa dentro do contexto social (DA SILVA \& VARELLA, 1999; KRUSE, 1999).

Estudos sobre uso ou orçamento do tempo permitem levar em conta aspectos multifatoriais, na medida em que retratam uma ampla gama de comportamentos observáveis sob forma de atividades diárias, executadas em diferentes ambientes e com diferentes parceiros 
sociais e, cujo resultado, pode direcionar a adoção de medidas preventivas a serem aplicadas á população idosa ou subgrupos dela.

A partir da obtenção de um quadro do modo como idosos de diferentes faixas etárias organizam sua vivência diária em termos de uso do tempo, tem-se inúmeros vislumbres dos seus estilos de vida, bem como do processo de envelhecimento ao longo do tempo.

Assim, priorizar em maior grau o envelhecimento sob o ponto de vista biológico, como quando avaliado somente através do binômio saúde-doença e reduzir ou excluir a importância do contexto físico e social ao se analisar as manifestações da vida diária do idoso, significa ignorar as riquezas de informações que estão presentes e que são fontes de conhecimento valiosas para uma melhor compreensão deste fenômeno, o qual tende a se tornar mais e mais visivel à sociedade e para o qual são urgentes a criação de programas e politicas especificas.

Explorar o cotidiano da pessoa idosa termos de planejamento de sua vida diária em relação ao tempo, significa buscar entender a heterogeneidade do seu conteúdo, a significação e importância das atividades ou seja, depara-se com sentidos, capacidades intelectuais, habilidades manipulativas, sentimentos, paixões e idéias do individuo interagindo pois, segundo HELLER (1985), "a vida cotidiana é a vida do homem inteiro".

O valor da informação sobre a utilização do tempo reside no fato de que tempo é um recurso fundamental e não renovável, sendo igualmente partilhado pois todos possuem, indistintamente, as mesmas vinte e quatro horas num dia.

Tendo o tempo como referência, este estudo busca descrever as atividades diárias de um grupo de mulheres idosas, pertencentes à um grupo de convivência, sendo este o primeiro passo para se compreender como as mesmas circulam pelo próprio ambiente para satisfazer necessidades e realizar objetivos. 
Para melhor compreensão do tema, a revisão de literatura abordará um breve histórico sobre a origem e importância das pesquisas de uso do tempo, enfatizando sua importância crescente em diversos paises, principalmente os desenvolvidos e o grande leque de utilização do método, prestando-se para avaliar desde aspectos econômicos até psicossociais.

A forma como as atividades diárias são padronizadas, de modo a oferecer um perfil adequado de como o tempo é usado na execução das mesmas, será abordado ao se tratar das classificações existentes para esta finalidade.

Num segundo momento, serão apresentados conceitos diretamente ligados ao processo de envelhecimento, como competência diária, autonomia e independência, por se tratarem de indicadores de saúde muito utilizados na área de geriatria e gerontologia e estarem diretamente relacionados ao desempenho de atividades diárias.

A estruturação das atividades em função do tempo que, em última análise, representa o conteúdo do dia vivenciado, bem como seus fatores determinantes, serão analisados em tópico específico.

Os (poucos) estudos de uso do tempo com indivíduos idosos e as dificuldades próprias de um trabalho dessa natureza com esta parcela da população tambèm merecem comentários.

Não é possivel referir-se ao uso do tempo sem discorrer sobre estilo de vida pois, em última instância, o uso que se faz dele é um reflexo da cultura e do modo de vida de uma sociedade.

Finalizando, a evidente feminização do envelhecimento também será comentado, em virtude do impacto deste fenômeno para muitas sociedades e da necessidade de prevenir e retardar incapacidades neste segmento populacional. 


\section{JUSTIFICATIVA}

A vida cotidiana de todo ser é permeada pela heterogeneidade especialmente no que se refere ao conteúdo e à significação ou importância dos tipos de atividades desenvolvidas.

Segundo HELLER (1985), a vida cotidiana é orgânica, fazendo parte da mesma aspectos como a organização do trabalho e da vida privada, lazer e descanso, atividade social, intercâmbio e religiosidade. Em outras palavras, o estudo da estrutura e organização da vida diária de pessoas, em especial as idosas, extrapola a esfera biomédica tradicional, ao levar em conta as circunstâncias naturais de suas vidas (MOSS \& LAWTON, 1982; BALTES et al., 1990; AGS, 1993; WAHL, 1998; UMEZAKI et al., 1999).

Além de fornecer um quadro geral da vida cotidiana, o conhecimento das atividades diárias tem sua importância na medida em que fornece uma descrição das motivações, objetivos, habilidades, preferências, necessidades e desejos das pessoas. Também evidenciam o grau com que suas atividades são afetadas por oportunidades e restrições externas já que estas podem fomentar ou retardar a participação em certos tipos de atividades e mesmo interferir na estruturação do dia-a-dia.

A vivência de um dia representa uma unidade de tempo permeada pelo contexto físico e social, o qual cria oportunidades e restrições para a manifestação de comportamentos e atividades, conforme o nível de autonomia e independência individuais (HORGAS et al. 1998). Neste sentido, considera-se que as atividades diárias desenvolvidas pela pessoa idosa não existem em um vácuo, mas implicam em sua adaptação ativa em relação à uma variedade de condições ambientais.

Conhecer o dia-a-dia desta população em termos de como o tempo é utilizado na estruturação de atividades diárias justifica-se porque: a) o quadro obtido pode fornecer um vislumbre representativo destas atividades e dos fatores que influenciam no seu engajamento; b) 
inteirar-se delas no próprio ambiente da pessoa possibilita conhecer os modelos de atividades por ela desenvolvidos bem como sua distribuição ao longo de um período de tempo especifico; c) o conhecimento obtido pode ser utilizado na implementação de programas voltados para favorecer uma melhor qualidade de vida desta população; d) o padrão de estruturação do dia poderia ser um meio útil de predizer ou diagnosticar mudanças de desempenho ao longo do tempo e e) evidencia como a associação entre desempenho em diferentes domínios e a pressão ambiental resultam em diferentes comportamentos.

Uma forma de abordagem não freqüente mas perfeitamente útil se utilizada para compreender o estilo de vida de diferentes individuos, pode ser feita conhecendo-se a estrutura do dia-a-dia através de estudos de uso do tempo (ou orçamento do tempo). Esta metodologia permite determinar, com relativa objetividade, como, quando, onde e com quem o dia é "gasto"/estruturado e outras caracteristicas do fluxo diário de atividades, preservando muito do conteúdo dinâmico/natural que define as experiências do cotidiano (MOSS \& LAWTON, 1982; ALBERT, 2000).

A descrição da estruturação da vida diária dos idosos a partir de estudos de uso do tempo e a influência de variáveis sobre o engajamento em atividades, tem o mérito de fornecer um primeiro vislumbre sobre a competência diária destes indivíduos, refletir diferenças em termos de estilos de vida e, mais importante, poder fornecer a chave para aumento na qualidade de vida desta população na medida em que aponta para possíveis áreas que demandem necessidade de intervenção, retardando a instalação de agravos que levam ao comprometimento da autonomia e independência (MOSS \& LAWTON, 1982; AGS, 1993).

Neste trabalho, optou-se por trabalhar apenas com o sexo feminino. A escolha vem do fato de ser este o maior contingente da população idosa em todas as idades acima dos 65 anos e também por se constituir no grupo que apresenta maior longevidade, 
principalmente nas faixas etárias maiores (acima dos 80 anos e mais) (WHO, 1999).

A longevidade feminina é um fenômeno recente que gera muitas implicações pessoais e sociais, necessitando de intervenções tanto em termos de serviços de saúde como da promoção da saúde (WHO, 1984; RAMOS et al., 1998).

Segundo a Organização Panamericana de Saúde (1994), as mulheres devem receber atenção especial das políticas de saúde pois, na atualidade, o que se observa é que muitas das necessidades dos mais velhos são, em realidade, necessidades das mulheres.

$\mathrm{O}$ número de pesquisas envolvendo o sexo feminino também poderia contribuir para aumentar o interesse em diversas questões e áreas do envelhecimento que afetam este grupo como por exemplo declínio funcional e deterioração da qualidade de vida (AGS, 1993).

Assim, a partir de um estudo descritivo, este trabalho tem como finalidade descrever a utilização do tempo na realização de atividades diárias de mulheres idosas, participantes de um grupo de convivência, com idades a partir de 60 anos e mais, levando-se em conta os contextos físico e social onde tais atividades ocorrem, obtendo-se assim um quadro do estilo de vida das participantes. 


\section{REVISÃO DE LITERATURA}

Entender o uso que pessoas fazem do seu tempo vem tornando-se necessário para se compreender a relação deste recurso e a manifestação da vida diária em várias instâncias, dentro da dinâmica de determinada sociedade.

Dados sobre o modo como individuos usam seu tempo na execução das atividades diárias podem ser utilizados para responder questões sobre uma ampla gama de assuntos, desde econômicos, sociais e psicológicos, constituindo-se, portanto, num instrumento de múltiplo uso. Contudo, sua aplicação é mais restrita a países desenvolvidos, sendo praticamente desconhecida no Brasil, principalmente no âmbito da gerontologia .

Um dos aspectos fascinantes do estudo do tempo é que ele é uma espécie de janela para uma cultura, permitindo conhecer o que nela se valoriza e no que se acredita.

\subsection{Origem e importância dos estudos sobre uso do tempo}

Atualmente, paises como Canadá, Nova Zelândia, Japão, Itália, Alemanha, Suécia, França e Austrália, dentre outros, consideram os estudos de uso do tempo essenciais para melhor elaborar, implementar e avaliar suas políticas de desenvolvimento econômico e social, além de enriquecer o conhecimento sobre suas sociedades ou grupos de pessoas.

A popularidade dos dados sobre uso do tempo nestes países está diretamente relacionada à sua versatilidade e ampla gama de utilização - que permite a emergência de novas aplicações. A riqueza e diversidade da informação gerada e o alcance das análises fazem das pesquisas de uso do tempo parte essencial dos programas estatísticos dos paises que as adotam (FLEMING \& SPELLERBERG, 1999).

O valor das informações sobre o uso do tempo reside no fato de que tempo é um recurso fundamental, não sofrendo influências 
culturais ou econômicas em termos de como é partilhado ou seja, cada pessoa possui as mesmas 24 horas num dia, independente do local ou condição de vida. Dessa forma, toda análise comparativa do seu uso permite começar com o mesmo ponto de partida para todos, mesmo que a alocação do tempo sofra ampla variação. Contudo, a forma de perceber e usar o tempo reflete as prioridades e a visão de mundo de uma cultura e, assim, depara-se com modos diferentes de se lidar com o tempo, numa base cotidiana (EZZELL, 2002).

De acordo com GERSHUNY (1992), estudos de uso do tempo fornecem a base para avaliar como pessoas utilizam seu tempo, diariamente ou semanalmente, além de revelar detalhes da vida diária de um indivíduo com uma combinação de especificidade e compreensão não possíveis através de outro tipo de pesquisa social. Segundo o autor, em paises desenvolvidos e em desenvolvimento, o principal objetivo das pesquisas de uso do tempo é direcionado às questões de gênero e trabalho, especialmente a divisão do trabalho no ambiente doméstico, incluindo mudanças na alocação do tempo através de ampla gama de categorias de atividades e também objetivando uma melhor mensuração do trabalho não remunerado feito pelo sexo feminino.

Estatísticas de uso do tempo constituem-se num recurso único, capazes de gerar informações relativamente detalhadas sobre sua utilização bem como a extensão da participação de homens, mulheres e crianças em todos os tipos de atividades produtivas, dentro e fora do ambiente doméstico.

Os dados são extremamente úteis porque cobrem ampla gama de atividades domésticas em geral não captadas através dos conceitos tradicionais de força de trabalho e produção, além de fornecer medidas mais fidedignas da atividade produtiva caseira em comparação com as estatísticas de trabalho tradicional (por exemplo, agricultura de subsistência). Isto é possível porque tempo, enquanto unidade básica de medida, permite um grau maior de desagregação em relação à 
conceitos tradicionais de participação e não participação em determinadas atividades (United Nations, 1978).

Em termos economicos, tempo pode ser convertido em dinheiro, bens e serviços produzidos. Da mesma forma, tempo é necessário para o consumo destes mesmos bens e serviços o que permite, então, estabelecer uma relação temporal entre produção e consumo. Por outro lado, tempo é consumido na força de trabalho, onde seu valor é avaliado em termos monetários. É o tempo também que permeia a realização do trabalho não remunerado, do trabalho voluntário, trabalho doméstico, as atividades sociais, de lazer e de autocuidado.

Cada um dos aspectos citados pode ser verificado por métodos especificos mas, somente o estudo do uso do tempo fornece um quadro integrativo de como atividades remuneradas, não remuneradas, voluntárias, domésticas, sociais, educacionais, de lazer e de cuidados pessoais encontram-se integradas na vida de diferentes populações ou seus subgrupos.

O quadro não somente leva a uma melhor compreensão da vida social como também fornece uma visão mais completa da economia nacional porque permite a quantificação e valoração da produção de bens e serviços produzidos fora do padrão convencional, os quais não são capturados através das medidas usuais de produção (FLEMING \& SPELLERBERG, 1999).

Os resultados destas pesquisas permitem aprimorar as estimativas das contas nacionais, quantificar e atribuir valores para a produção doméstica e trabalho não remunerado, possibilitam um melhor conhecimento das atividades econômicas das mulheres, aprimoram as estatísticas dos segmentos de trabalho de difícil mensuração bem como obtenção de melhor imagem e registro das condições e estilos de vida e de padrões de uso do tempo de diversas categorias sociais (JOYCE \& STEWART, 1999).

Segundo Iiris Niemi (1995) citado por FLEMING \& SPELLERBERG $(1999$, p.7), a origem dos estudos sobre uso do tempo 
deu-se na Inglaterra e França, ao final de 1900, com o objetivo de avaliar as condições de vida de suas classes trabalhadoras, onde os comportamentos observáveis eram medidos em termos do uso do tempo em horas e minutos. Os Estados Unidos também fizeram uso do método antes da segunda guerra mundial com o intuito de investigar diversos aspectos de sua população.

A realização de pesquisas sobre uso do tempo foram esporádicas até a realização, nos anos sessenta, de um grande estudo comparativo denominado Multinational Comparative Time-Budget Research Project, envolvendo 12 países e coordenado pelo pesquisador Alexander Szalai (HORGAS et al., 1998). Infelizmente, este estudo, que reuniu informações sobre mais de trinta mil pessoas, omitiu de seu universo o individuo idoso (MOSS \& LAWTON, 1982) porem, estabeleceu inúmeras convenções com relação às pesquisas de uso do tempo que permitem comparações entre as mesmas como também constituiu um grupo de pesquisadores sobre o assunto.

Este grupo forma o International Association for Time Use Research - IATUR, o qual, além de congregar pesquisadores de várias partes do mundo, realiza conferências freqüentes com o intuito de prover informações sobre este método e suas constantes aplicações, refinando-o para aplicabilidade e comparabilidade internacional.

Como mencionado, dados de uso do tempo possuem ampla variedade de uso, na medida em que disponibilizam e integram ampla gama de informações sobre as atividades de determinada população. Os estudos permitem verificar o desenrolar de atividades específicas dentro do contexto de outras atividades, relacionando-as ao contexto demográfico e sócio econômico onde as mesmas são observadas, sendo também possivel verificar atividades simultâneas àquelas consideradas principais e o contexto físico e social onde ocorrem. 


\subsection{Utilização dos dados sobre uso do tempo}

Pesquisas sobre uso do tempo inicialmente eram usadas para verificar tendências e mudanças nas populações e também para avaliar seus estilos de vida e bem estar.

A consistência do método e as categorias analiticas introduzidas após a realização do Multinational Comparative Time-Budget Research Project anteriormente mencionado, tornaram possiveis comparações de pesquisas sobre uso do tempo realizadas em diferentes épocas e em diferentes nações. Assim, a medida do uso do tempo pode ser vista como uma unidade internacional de medida que pode ser usada em diferentes culturas para analisar a duração, seqüência e coordenação das atividades humanas.

De acordo com FLEMING e SPELLERBERG (1999) e JOYCE e STEWART (1999), vários são os usos deste método. Um dos mais comuns refere-se à verificação de tendências junto à população. Neste tipo de estudo, as comparações são centradas na relação entre quatro amplas categorias: trabalho remunerado, não remunerado, lazer ou tempo livre e cuidados pessoais incluindo o sono. A quantidade de tempo (em horas e minutos) gasto em cada categoria (que pode ser dividida em subcategorias) é avaliado para a população como um todo e para diferentes grupos dentro dela. A partir da reaplicação do estudo e comparação dos resultados, pode-se obter o quadro das mudanças que incidem na sociedade ou grupos.

Outra aplicação refere-se ao estudo dos estilos e padrões de vida dentro de uma mesma sociedade ou entre várias sociedades com a finalidade de se verificar similaridades e diferenças nos padrões de uso do tempo. Neste tipo de estudo, a quantidade de tempo livre para descanso e atividades recreativas é um aspecto importante do bem estar pessoal, sendo uma medida de qualidade de vida de determinada população. Tal medida respalda-se na teoria da atividade, para a qual pessoas serão mais felizes e com maior grau de realização pessoal na 
proporção direta da quantidade de atividade que elas são capazes de manter ao longo do processo de envelhecimento (MANELL, 1999).

$O$ exame de aspectos especificos de qualidade de vida de diferentes paises também utiliza o uso do tempo. Aspectos como contato social, modelos de tempo dispendido pelas mulheres no trabalho doméstico e no trabalho remunerado, alta carga de trabalho/responsabilidades imposto às mulheres e pobreza permitem avaliar a qualidade de vida ao longo do tempo.

Outros usos, dentre outros, referem-se ao estudo do trabalho voluntário, dos aspectos legais e jurídicos (nos países desenvolvidos, a partir do momento que a mensuração do trabalho doméstico não remunerado vem tornando-se aceita como informação estatística, esta pode ser usada como evidência nos processos litigiosos), planejamento urbano (distribuição das atividades entre a casa e espaços públicos), atividades de lazer, cuidadores (idosos e crianças), modo de vida de crianças e jovens, estudos psicossociais (isolamento e alienação), comportamentos de consumo, além de estudos sobre envelhecimento e estilo de vida de pessoas idosas.

\subsection{Classificações internacionais para estudos de uso do tempo}

Muitos paises conduzem com freqüencia pesquisas sobre uso do tempo e, devido aos objetivos similares de muitas delas e desejo em se comparar os resultados entre países, há um enorme engajamento com o intuito de padronizar a coleção de dados destes estudos.

Vários sistemas de classificação e suas respectivas codificações tem como base a estrutura original desenvolvida no estudo de Alexander Szalai na década de sessenta (STINSON 1999).

Os códigos das atividades são tipicamente organizados em grupos de comportamentos observáveis mutuamente exclusivos de modo a cobrir todos os aspectos da atividade humana. Os grupos principais (ou primários) destes comportamentos, em geral incluem atividades de cuidado pessoal, atividades relacionadas ao trabalho, 
atividades educacionais, atividades domésticas, cuidados com crianças, aquisição de bens e serviços, trabalho voluntário e atividades de cuidador, atividades sociais e comunitárias, recreação e lazer e viagens.

Os sistemas de classificações não só buscam refletir distinções significativas entre grupos de atividades especificas para propósito de tabulação de dados, como também tentam priorizar determinadas distinções de modo que estas forneçam uma base conceitual sólida para as análises estatísticas, de acordo com os objetivos da pesquisa.

Aas (1982) citado por STINSON (1999, p.16), a partir de uma análise lógica de atividades e comportamentos de uso do tempo, identificou três dimensões inseparáveis para relação tempo-atividade: l) a própria atividade (ou ação), significando o comportamento observável; 2) onde ela é realizada, significando o local ou espaço físico e 3) na presença de quem ela é realizada, significando a interação ou contexto social. Com base nesta análise, o autor propôs uma tipologia, composta por quatro categorias de tempo: 1) tempo necessário, utilizado na execução de cuidados pessoais, inclui atividades ligadas à saúde e às necessidades fisiológicas básicas como dormir, comer e higiene; 2) tempo contratado, relacionado às atividades de emprego e educação regular, onde há alocação explícita de um periodo de tempo, restringindo assim, a distribuição de outras atividades ao longo do dia; 3 ) tempo comprometido, relacionado às atividades obrigatórias (trabalho doméstico, cuidados com os familiares, adquirindo bens e serviços para a própria casa, trabalho não remunerado fora de casa) mas cuja obrigatoriedade pode ser substituída pela compra de um serviço (por exemplo, a contratação de uma diarista para executar a limpeza da casa) e 4) tempo livre (atividades religiosas, culturais e cívicas, sociais, esportes e atividades de lazer), tempo que permanece após a exclusão dos três primeiros tipos. Neste último caso, muitas atividades de tempo livre podem ser consideradas como lazer. Porém, lazer é algo subjetivo 
porque depende do ponto de vista pessoal. També forma, muitas atividades incluidas na categoria de tempo comprometido podem ser consideradas como atividades de lazer por algumas pessoas. Vale ressaltar que o aumento na porção de tempo livre só se dará através de alterações nas proporções de tempo contratado e/ou comprometido já que o tempo total disponivel em um dia é constante para todo individuo.

Internacionalmente existem vários códigos de classificação de atividades diárias e, pelo fato de se reportarem à mesma fonte que thes serve de base, partilham inúmeras similaridades. Porém, com o intuito de se realizarem comparações entre paises, tem havido uma tentativa para a padronização da coleção de dados.

Tendo por base a tipologia mencionada e, devido a coesão que a mesma apresenta, todos os estudos de uso do tempo utilizam para sua análise e comunicação de resultados esta estrutura conceitual. Isto porque, todas as atividades humanas podem ser colocadas dentro de uma destas quatro definições e a ordem de tais definições descreve a prioridade com que o tempo, em um dia, pode ser alocado.

Muitas pesquisas podem levar em conta certas características culturais e interesses específicos de um país ou população o que implica em decisões metodológicas, decisões estas que devem ser pensadas em termos de vantagens e desvantagens antes de serem adotadas. Contudo, é importante ressaltar que todas as classificações adotadas pelos vários países que conduzem tal tipo de pesquisa, passaram pelo rigor estatístico, tendo sido considerados aspectos como métodos de coleta de dados, população de interesse, tamanho e seleção da amostra, código das atividades, período de pesquisa, dentre outros (FLEMING \& SPELLERBERG, 1999). Assim, ao selecionar/adotar uma classificação já existente, previamente se beneficia dos testes aos quais ela foi submetida, bem como das revisões de códigos das atividades, economizando tempo e recursos financeiros. 
Em linhas gerais, cada classificação é constituida por grupos de atividades principais ou grupos primários (em torno de 10 grupos) que, juntos, englobam todos os aspectos da atividade humana. Por sua vez, cada grupo engloba uma série de atividades relacionadas (atividades secundárias), em niveis mais detalhados e variados, podendo até existir subgrupos de atividades secundárias. Esta variedade de atividades torna-se responsável pelas diferenças entre as classifiçações. Tal variedade se faz necessária porque é a nivel das atividades secundárias que se introduz atividades especificas da cultura de um país ou população e atividades que se deseja obter um conhecimento mais apurado.

As atividades do grupo principal são codificadas com um digito, atividades secundárias com dois dígitos e subdivisões de uma mesma atividade secundária recebem três dígitos. Como exemplo, cita-se um item da classificação utilizada pela Nova Zelândia (Statistic New Zealand, 1999), onde a participação em atividades religiosas, culturais e civicas (grupo principal) tem como dígito/código o número 8 . A participação em cerimonias ou rituais especificos da cultura maori recebe o dígito/código 83 (atividade secundária). As viagens associadas à participação em cerimonias ou rituais especificos da cultura maori recebe o digito/código 838 (subdivisão de atividade secundária). $\mathrm{Na}$ classificação australiana (Australian Bureau of Statistic, 1999), atividades religiosas, culturais e cívicas estão inseridas no grupo principal denominado Interação Social e Comunitária, que também recebe o código 8 porém sem apresentar especificidade cultural.

STINSON (1999) menciona o cuidado que se deve ter com relação à consistência da codificação das atividades se o objetivo for uma comparação internacional. Para tanto, a escolha do sistema de classificação a ser adotado merece atenção. Segundo a autora, existem três classificações amplamente utilizadas. 
A primeira, Eurostat, elaborada em 1993, sofreu refinamentos em 1995, a partir de uma colaboração entre Inglaterra, Finlândia e Suécia. Até hoje, vários paises tem partilhado o uso desta classificação com a vantagem de uma comparação internacional direta, enquanto mantém a oportunidade para realizar adaptações culturais específicas em nível de três digitos.

Já o sistema de classificação da Austrália tem a vantagem de ter sido tesțado e criticado desde 1992, tendo sido revisado em 1997. A base conceitual desta classificação também apoia-se na tipologia do tempo descrita por Aas (1982) citado por STINSON (1999, p.16), guardando uma relação hierárquica entre seus nove grupos de atividades principais. Uma das preocupações para com o instrumento foi ajustar a distribuição do tempo dentro das categorias principais através da redefinição ou reagrupamento de algumas destas categorias.

Outra classificação foi elaborada pelas Nações Unidas. A mesma passou por uma revisão a pedido da própria instituição, objetivando fornecer uma codificação internacional de análise a fim de possibilitar a compreensão do uso do tempo em uma ampla gama de diferentes sociedades. Contudo, sua base conceitual é claramente econômica, sendo especialmente útil no estudo da força economicamente ativa de um pais.

As revisões freqüentes nestas classificações, em especial até 1997, objetivaram adequá-las visando melhor comparação pois, em 1997, além da Austrália, outros dezoito paises conduziram pesquisas para estudos de uso do tempo (STINSON (1999).

Apesar destas três classificações partilharem da origem comum, elas se opõem na medida em que a classificação australiana encerra uma coesão analítica e uma explicação teórica bem estruturada para o uso do tempo. Já a classificação Eurostat tem como direcionamento sua aplicação nos países europeus unificados e a classificação das Nações Unidas torna-se atraente pelo fundamento econômico que encerra. 
Embora vários paises façam uso de pesquisas de uso do tempo tendo inumeros interesses em comum, em geral tais interesses não são identicos porque, como qualquer outra pesquisa, pesquisas de uso do tempo são conduzidas para responder questões específicas e estas variam de um pais para outro. Portanto, a escolha da classificação deverá levar em conta os objetivos traçados e que os resultados possam ter a maior comparabilidade internacional possivel.

Neste tipo de estudo, os dados podem ser coletados de várias formas: questões estilizadas (o respondente deve recordar a quantidade de tempo alocado para o desempenho de uma atividade específica), listas de atividades específicas (deve recordar a quantidade de tempo alocado para determinadas atividades), "beeper studies" (deve anotar informações pré determinadas ao soar do "beep"), diários (deve anotar, ou recordar, em sucessão, todas as atividades realizadas em um determinado período), entre outras.

O diário é um dos modos mais utilizados de coletar informações porque permite variações do método, de acordo com os objetivos da pesquisa. Assim, pode-se escolher realizá-lo sob forma de entrevista face a face ou por telefone ou então o emprego do diário propriamente dito, onde a pessoa registra suas atividades conforme vai realizandoas. Contudo, cada variação tem suas vantagens e desvantagens que interferem na qualidade do resultado devendo, portanto, serem levadas em consideração quando da realização da pesquisa (Statistic New Zealand, 1999).

\subsection{Conceitos de competência diária}

Atualmente, preconiza-se a adoção de hábitos e medidas preventivas por parte das pessoas idosas para que possam ter uma vida o mais ativa e independente possivel, retardando o aparecimento de doenças incapacitantes e a necessidade de cuidados formais de longa duração, principalmente por parte do setor público. 
FRIES (1980) articula um cenário para a questão do envelhecimento ao postular que a duração da vida humana, se ocorrendo sob condições satisfatórias, poderá ser fixada em 85 anos, em média, onde a morte natural poderá ocorrer sem a presença de doenças. Além disso, o autor salienta que o inicio das doenças e incapacidades poderão ser retardados cada vez mais, restringindo a ocorrência e duração dos agravos para os últimos anos da vida. Esta visão de aumento da extensão da expectativa de vida seria possível através da retangularização da curva de morbidade, num processo por ele denominado compressão da morbidade.

SCHNEIDER \& BRODY (1983) opõem-se ao cenário descrito anteriormente, mencionando que a expectativa ou esperança de vida é inexata e, além disso, faltam evidências de que esteja ocorrendo um declínio dos indices de morbidade e incapacidades em diferentes grupos etários ou seja, não se observa uma tendência de declínio na incidência e prevalência de doenças.

Tanto a visão de FRIES (1980) como a visão de SCHNEIDER \& BRODY (1983) fazem parte do mesmo modelo convencional, baseado na dicotomia envelhecimento "normal" e "anormal" ou "patológico", onde os estudos objetivam separar as mudanças patológicas daquelas que podem ser atribuídas unicamente ao processo de envelhecimento.

Paralelamente, outro conceito foi proposto por ROWE \& KAHN (1987), o de envelhecimento bem sucedido, que inclui três componentes principais: 1) baixa probabilidade de doenças e doenças relacionadas à incapacidades, 2) alta capacidade funcional cognitiva e física e 3) compromisso ativo com a vida. Segundo os autores, envelhecimento bem sucedido é mais que a ausência de doenças e manutenção de capacidade funcional, embora sejam dois componentes importantíssimos.

CROWTHER e colaboradores (2002) propuseram incluir no modelo acima um quarto componente, a espiritualidade positiva, que considera o desenvolvimento e internalização de uma relação pessoal 
com o sagrado, independente de raça, classe social ou aspectos econômicos. Para eles, este componente, além de intimamente ligado ao bem estar, tem forte impacto no restabelecimento e manutenção da saúde da pessoa idosa.

A pesquisa gerontológica sobre a capacidade funcional de idosos tem um passado muito rico, sendo fonte de grande parte do conhecimento sobre esta população (KATZ et al., 1963; LAWTON \& BRODY, 1969; LAWTON, 1983), embora, em sua origem, tenha sido claramente realizada sob uma ótica "medicalizada" ou seja, baseada apenas no binômio saúde-doença.

$\mathrm{Na}$ atualidade, verifica-se um aumento de estudos que consideram os vários contextos do envelhecimento, em especial, estudos sobre a competência diária (BALTES et al., 1990; BALTES et al., 1993; WILLIS, 1996; WAHL, 1998; DIEHL, 1998), não somente como reação às mudanças na estrutura etária de diversas sociedades (KALACHE et al., 1987; CHAIMOWICZ, 1997; VOLZ, 2000), mas também como resposta às novas necessidades que esta situação em si impõe aos diversos paises que se deparam com esta problemática.

É fato sabido que, enquanto grupo, pessoas idosas são as maiores usuárias dos serviços de saúde, consumindo grande parte do orçamento destinado a este setor (BERQUÓ 1996; CHAIMOWICZ, 1997; SAYEG, 1998). Dessa forma, a capacidade para cuidar de si próprio, de administrar sua vida de modo a viver independentemente na comunidade, torna-se de grande importância não somente para estas pessoas, mas para a sociedade como um todo.

Para LAWTON (1983), o termo competência tem sido usado por muitos pesquisadores para definir qualidades pessoais desejáveis, cuja exibição evidenciam um comportamento adaptativo ao meio ambiente. Para ele, competencia refere-se ao limite superior de capacidade individual para funcionar adequadamente nas áreas da saúde biológica, emoção e percepção, comportamento motor e cognição. Todos esses 
constructos não podem ser avaliados diretamente, de modo que o único meio para se medir competência é através da definição de comportamentos que implicam na presença de algum elemento de competência. Por exemplo, respirar e andar são indicadores de saúde biológica, enquanto os resultados de um teste para solução de problemas são indicadores comportamentais de inteligência.

Para BALTES e colaboradores (1993), o termo competencia possui muitas definições, podendo conceitualmente variar desde motivações à habilidades mas, todas podem ser agrupadas de modo a fornecer três dimensões de competência.

A primeira diz respeito à perspectiva de habilidade na qual competência reflete a extensão e níveis de habilidades nos domínios social, cognitivo e emocional. A segunda dimensão de competência refere-se à perspectiva de controle ou auto-eficiência a qual relacionase à crença pessoal daquilo que se é capaz de fazer e sobre que tipos de situações se tem controle. Finalizando, competência também tem sido considerada dentro de uma perspectiva adaptativa, enfatizando uma combinação entre habilidades pessoais e demandas ambientais específicas. Dessa forma, competência diária implica numa concepção multidimensional ou seja, numa gerência efetiva da vida diária, requerendo uma orquestração de habilidades que variam desde aquelas requeridas para cuidado pessoal (atividades rotineiras, habituais), passando pelas atividades de lazer até aquelas consideradas atividades instrumentais expandidas, relacionadas com o aspecto motivacional e preferências individuais.

De acordo com WILLIS (1996) e DIEHL (1998), o termo competência diária refere-se à habilidade para executar, quando necessário, ampla gama de atividades consideradas essenciais para uma vida independente mesmo que, no dia-a-dia, a pessoa não necessite executar tais tarefas de modo regular ou então as execute parcialmente. 
Para SALTHOUSE (1990), esta definição refere-se à capacidade ou ao potencial do individuo para executar determinadas tarefas e não simplesmente ao comportamento diário observável

O termo competência e potencial são conceitos teóricos que evocam condições ou estados que não podem ser vistos diretamente, a não ser pelos seus reflexos ou sinais comportamentais (WILLIS, 1996) ou seja, pelas atividades cotidianas observáveis.

A distinção entre o verdadeiro potencial individual e as ações comportamentais observáveis torna-se importante porque pesquisas na área da psicologia indicam que diferentes fatores podem estar envolvidos em determinar (explicar) se 0 indivíduo tem verdadeiramente competencia ou habilidade ou se o individuo executa uma atividade somente quando esta é requerida ou necessária. Por exemplo, patologias cerebrais podem implicar em alterações irreversiveis na habilidade cognitiva eliminando o potencial individual porém, uma pessoa sem tais alterações, pode ser capaz de executar determinada atividade mas não o faz devido a fatores como desconfiança no próprio potencial pessoal ou depressão (WILLIS, 1996).

Estudos de competência tem recebido especial atenção não somente das áreas da psicologia do desenvolvimento, saúde $\mathrm{e}$ cièncias sociais, mas também da área advocatícia em termos da capacidade e autonomia da pessoa idosa frente às decisões legais (WINNINGER, 1995; STAHELIN, 1997). Neste sentido, a preocupação não é somente com o aspecto cognitivo como tradicionalmente estudado em laboratório, mas com a cognição aplicada ou inteligência prática, ou seja, a incompetência legal significa que uma pessoa, devido a ausência de capacidade para contemplar as próprias escolhas de modo lógico e racional, não pode cuidar adequadamente de si próprio e de seus bens materiais. 
Outro aspecto importante diz respeito ao fenômeno multidimensional da competência diária, pois esta envolve múltiplos domínios e múltiplos componentes.

Por múltiplos domínios entende-se os aspectos físico, psicológico (emocional e cognição) e social interagindo de modo complexo para produzir os comportamentos e ações externalizados. Cada um destes domínios, por sua vez, encerra uma multiplicidade de componentes como senso de controle e eficácia, modos de enfrentamento de situações estressantes, afetividade, habilidades para solução de problemas, dentre outros (MENDES DE LEON et al., 1996). Por exemplo, no domínio social, a competência diária inclui a habilidade do individuo em relacionar-se socialmente o que, por sua vez, poderá determinar a quantidade, tipo e qualidade de apoio disponivel na rede de suporte social que foi construída ao longo do tempo (DIEHL, 1998).

O estudo da competência diária de pessoas idosas deveria levar em conta os domínios de competência física, psicológica e social, pois a vida diária não existe num vácuo, mas é fruto de uma interação orgânica entre homem e meio ambiente. A expressão concreta desta interação varia de acordo com a cultura e com as mudanças tecnológicas, pois estas podem alterar o repertório de respostas comportamentais requerendo a incorporação de novas habilidades.

Portanto, a competência diária é um processo dinâmico onde, considerando uma dada atividade, o indivíduo exercita-se ao lidar com ela e seus vários aspectos, quantas vezes forem necessárias, até alcançar a solução final. Uma vez finalizado o problema, este pode ressurgir, exigindo nova solução, da mesma forma que mudanças contextuais irão requerer uma nova reorganização comportamental para resolver o problema adequadamente (WILLIS, 1996).

Um aspecto de particular importância refere-se ao grau e modo como se processam as alterações na competência diária em relação à idade. 
Estudo longitudinal de WIILIS e colaboradores (1992), utilizando-se de diversas baterias de teste aplicadas duas vezes num periodo de sete anos, demonstrou que houve declínio significativo na competência para execução de tarefas diárias. Contudo, os autores salientam que, se analisados pela média de declínio, os resultados concordam com outros estudos que apontam a idade como responsável pelos achados, sugerindo que a maioria dos individuos experimentam um declínio linear na habilidade de executar tarefas diárias. Porém, os dados claramente mostraram que o declinio linear não estava presente na maioria dos casos quando as trajetórias foram analisadas individualmente, mostrando a existência de diferenças individuais na proporção e no tempo em que as mudanças ocorriam. Embora se espere que, quanto mais idoso o indivíduo, maior o declinio vivenciado na competência para realização de tarefas diárias, os resultados indicam que o declínio para muitos idosos não acontece de modo linear, numa relação direta com o aumento da idade cronológica.

Portanto, não é o aumento em anos por si só o responsável pelas mudanças verificadas na competência diária, mas uma interação entre aspectos maturacionais e influências contextuais que podem contribuir para as mudanças cognitivas com o avançar da idade. Uma dessas influências poderia ser o grau de instrução pois, segundo WILLIS (1996), as taxas de declínio tornam-se particularmente pronunciadas quanto menor o grau de instrução do idoso.

De acordo com BALTES (1993), competência individual está intrinsicamente relacionada com os mecanismos cognitivos (inteligência fluida), determinados pela evolução da arquitetura neurofisiológica do cérebro e também pela cognição pragmática (inteligência cristalizada), esta reflexo do impacto da cultura sobre o individuo.

Os mecanismos cognitivos dizem respeito ao processamento de informações a nível sensorial, memória visual e motora e processos de discriminação, comparação e categorização. Já a cognição pragmática 
reflete o tipo de conhecimento e informação que o contexto cultural oferece a respeito do mundo, do homem e dos acontecimentos e que o individuo adquire quando participa do processo de socialização. São exemplos, dentre outros, as qualificações educacionais, habilidade profissional e tipos de conhecimento sobre o próprio ser e sobre a vida que auxiliam a pessoa a lidar com as vicissitudes da existência humana.

Ainda, segundo BALTES (1993), com relação aos mecanismos cognitivos, por se tratarem de fenômenos que são geneticamente e biologicamente controlados, é de se esperar que sobre estes se imponha uma perda ocasionada pelo processo de envelhecimento. $O$ oposto se verifica quanto à cognição pragmática que, por ser fundamentada na relação do individuo com sua cultura, mostra evidência de estabilidade e mudanças positivas em pessoas que alcançam idades mais avançadas sem a presença de patologias cerebrais e vivendo em circunstâncias favoráveis de vida. Esta necessidade de reestruturação constante frente a um contexto altamente móvel talvez seja um dos fatores responsáveis pela manutenção da competência diária da pessoa idosa porque implica na busca diária de equilibrio, fruto da dinâmica entre crescimento individual, baseado na cultura, e declinio funcional, baseado na biologia. O autor conclui que, quanto melhor for o "software" (cognição pragmática), melhores serão os níveis de performance (competência) mesmo que o "hardware" (mecanismos cognitivos) não esteja em boas condições.

PINQUART e SÖRENSEN (2000) salientam que um comportamento competente está diretamente ligado ao bem estar do idoso. Segundo os mesmos, quatro razões são apontadas para esta constatação. Primeiro, pelo fato de que, nas sociedades ocidentais, o individuo é visto como centro de escolha para ação, havendo consenso de que um alto nível de controle, autonomia e competência são necessários para otimizar o potencial humano. Em segundo lugar, 
niveis reduzidos de competência podem afetar a escolha de atividades que são fontes de prazer e satisfação. Em terceiro lugar, doenças e incapacidades podem afetar a qualidade dos relacionamentos sociais e, por último, a perda da competência pode reduzir a capacidade de auto-proteção contra os inconvenientes da vida.

\subsection{Conceitos de autonomia e independência}

Aṣ definições de competência,vistas anteriormente, são amplamente usadas pela área da psicologia do envelhecimento, cuja ênfase maior recai sobre o aspecto cognitivo.

Ao se considerar a abrangência biopsicosocial da competência, pode-se inferir que, em algum momento, haverá uma interface entre os conceitos de competência, autonomia e independência, razão pela qual algumas considerações serão feitas sobre os dois últimos aspectos.

Não se objetiva estabelecer semelhanças ou discordâncias sobre os termos e sim apresentá-los como mais dois conceitos que podem ser avaliados para melhor entender o processo de envelhecimento.

Os termos autonomia e independência são mais utilizados pela geriatria ao estudar a capacidade funcional, priorizando em maior grau o aspecto fisiológico do envelhecimento. Neste sentido, o que se avalia é uma condição ou então uma doença, baseada no relato do idoso e nos achados do examinador (PAULA et al., 1998).

A autonomia, que pode ser entendida como o ato de governar-se a si próprio, de modo geral, no âmbito da gerontologia, é compreendida como capacidade funcional ou capacidade para atividades básicas da vida diária (KATZ et al., 1963; DERNTL, 1998) e atividades instrumentais da vida diária (LAWTON \& BRODY, 1969).

Deve-se ter em mente que a pessoa idosa também têm como parâmetro de saúde uma vida independente sobre a qual possua controle, sem a necessidade de ser cuidada por terceiros. Neste sentindo, DUFFY e colaboradores (1990) mencionam que a definição 
de saúde por parte do idoso altera-se em função do tempo ou seja, seu conceito de saúde se amplia conforme envelhece, indo além do estado de saúde física.

A saúde é vista estando mais relacionada ao aspecto funcional ou seja, com as habilidades necessárias para se manter um estilo de vida próprio, fruto do desempenho de atividades diárias. Assim, uma vida mais saudável na velhice está diretamente ligada à manutenção ou restauração da autonomia e independência, dois indicadores de saúde.

Neste contexto, PASCHOAL (1997) define autonomia como a "capacidade de decisão, de comando" e independência como a "capacidade de realizar algo com seus próprios meios". O conceito de capacidade funcional integra estes dois aspectos, porque pressupõe um individuo capaz de manter habilidades físicas e cognitivas necessárias para uma vida independente e autônoma (ANKRI, 2000).

A autonomia, segundo FARINATTI (1997), muitas vezes é identificada e também confundida com ausências de incapacidades porque utiliza como padrão de referência escores de normalidade utilizados em testes clínicos, motores e psicológicos. Outras vezes, o enfoque é restritivo quando analisado como capacidade de executar atividades da vida diária (AVD), pois há a tendência em se associar autonomia à idéia de dependência social e, especialmente, de dependência física, adotando-se assim uma abordagem negativa. O autor salienta ainda que, na maioria das vezes, a abordagem médica tende a desconsiderar um ponto importante ou seja, os niveis de autonomia, que podem ser representados pelas possibilidades de se viver adequadamente e positivamente dentro de um quadro multifatorial, dentro de uma concepção biopsicosocial de saúde.

Para PASCHOAL (1997), pessoa autônoma é aquela da qual emana poder de decisão próprio, que constrói e direciona seu próprio caminho ou seja, o indivíduo se auto-comanda e determina sua legalidade, norteia-se, escolhe seus objetivos e estabelece caminhos para alcançar metas propostas. 
De acordo com EVANS (1984), autonomia é a capacidade individual para estabelecer e seguir metas próprias. Em seu ponto de vista, para um idoso, a autonomia é de maior utilidade que a independência em termos globais, pois pode ser preservada mesmo em presença de dependencia.

Segundo WILKIN (1990), a dependência refere-se à um estado relacional entre um individuo e outro (ou outros) para alcançar necessidades estabelecidas previamente.

Portanto, independência e dependência são conceitos que existem somente em relação à um padrão de comparação ou seja, no mesmo individuo é possivel distinguir um estado de independência (financeira, por exemplo) e dependência (afetiva, fisica, por exemplo) (PASCHOAL (1997).

Para uma análise mais esclarecedora e abrangente, FARINATTI (1997) propõe um modelo onde autonomia é expressa em três niveis distintos porém interligados: a) autonomia de ação, incorporando a noção de independência física e a possibilidade de mover-se livremente, sem obstáculos materiais ou constrangimentos físicos, permitindo satisfazer as necessidades do idoso dentro da dimensão física, b) autonomia de vontade ou de intenção, que incorpora as possibilidades de livre autodeterminação, representando um resultado ou então a manifestação de uma intenção e c) autonomia de pensamento, esta considerada o nivel mais profundo da autonomia porque implica em manisfestar julgamentos deliberados que necessitam conhecimento prévio, capacidade de compreensão, espirito crítico e consciência, todos integrados numa capacidade lúcida e coerente. Sob esse enfoque, autonomia não incorpora a idéia de tudo ou nada, mas, como um fenômeno multidimensional, possui inúmeras gradações, todas dependentes de fatores determinantes como o meio ambiente físico, humano (psicossocial) e condições orgânicas.

Diante de inúmeros conceitos, a Organização Mundial da Saúde (WHO, 1980) estabeleceu uma terminologia e um sistema de 
classificação, conceitualmente ligados. De acordo com o mesmo, a partir da doença, pode-se desencadear, pela ordem, os seguintes processos: a) deficiência (impairment): relacionado às funções biológicas, implica na anormalidade ou perda de uma estrutura ou função anatômica, fisiológica ou psicológica, detectada a partir da divergência de padrões de normalidade previamente estabelecidos; b) incapacidade (disability): qualquer restrição ou ausência (resultante de uma deficiência) de habilidade para externalizar/executar uma atividade (cognitiva ou física) do mesmo modo ou dentro do espectro considerado normal para um indivíduo; c) desvantagem (handicap): é uma desvantagem que limita ou impede a realização de uma ação normal por parte do individuo; ela representa a conseqüência social da deficiência ou da incapacidade constituindo-se num fenômeno social, cujo parâmetro de normalidade é ditado pelas atitudes e valores daqueles que não apresentam a mesma desvantagem.

Definições à parte, pode-se inferir que, na vida do idoso, a presença de um ou mais dos agravos mencionados tem interferência direta sobre a execução das atividades diárias, na medida em que irão determinar a variedade, amplitude e qualidade do seu cotidiano. Na tentativa de adaptar-se às circunstâncias, tais agravos irão exigir do idoso a busca de estratégias para superar ou atingir um estado de equilíbrio, de modo que ele possa conviver com as limitações o mais satisfatoriamente possivel.

A deficiência e incapacidade podem ou não levar à dependência do mesmo modo como podem conduzir à desvantagem. Contudo, dependência e desvantagem não devem ser equiparados nem deve haver uma relação necessária pois, embora possam ter uma origem comum (a doença), retratam conseqüências sociais distintas na medida em que é a sociedade quem decide sobre suas definições e existência (BOWLING, 1992).

De modo geral, a desvantagem é a limitação ou impedimento para realização de uma ação normal por parte do próprio individuo, 
enquanto na dependência este necessita da presença de terceiros para alcançar seus objetivos.

Estes dois aspectos, em seus diversos graus de manifestação, podem agravar a necessidade de cuidados especializados de longa duração, elevando os custos sociais em decorrência do aumento do número de pessoas idosas, principalmente em países subdesenvolvidos e em desenvolvimento que ainda não possuem um planejamento de atendimento adequado a esta população (KALACHE et al., 1987; SILVESTRE et al., 1996; CHAIMOWICZ, 1997).

Dado que os riscos de comprometimento da capacidade funcional aumentam com a idade, podendo levar a perda da autonomia e independência, torna-se importante diminuir o número de pessoas que desenvolvem dependências funcionais. Tal objetivo faz parte da promoção da saúde, a qual ganha um enfoque mais abrangente $e$ multifatorial, como também faz parte de um conjunto de medidas visando manter o idoso o mais distante possivel da necessidade de utilização da rede de serviços especializados.

De acordo com SIN e colaboradores (1993), há três abordagens para se evitar ou diminuir as necessidades de cuidado institucional de longa duração: a) aumentando a disposição de cuidado informal fora das instituições, enfatizando-se mais o cuido familiar e comunitário, b) aumentando o cuidado formal não institucional de longa duração, viabilizado através de políticas oficiais ou não, visando retardar a institucionalização e c) diminuindo o número de idosos que desenvolvem dependências funcionais, esta a melhor mas a mais difícil das abordagens. A proposta objetiva diminuir a velocidade de instalação de processos envolvidos no declínio funcional e é -operacionalizada através da prevenção de doenças, seqüelas e suas complicações, bem como promoção e proteção da saúde das futuras coortes de individuos ingressantes na chamada terceira idade. 
Um dos fatores que podem acelerar o declinio funcional diz respeito à inatividade física (DALEY et al., 2000; MATSUDO et al., 2000; RAUCHBACH, 1998).

Embora não se tenha a comprovação de que exercício aumente a expectativa de vida, a atividade física exerce um importante papel, aumentando a qualidade de vida das pessoas (SHEPHARD, 1993; KHAW, 1997; BLAIN et al., 2000).

Muitas das alterações na estrutura fisiológica e na função orgânica que ocorrem com o envelhecimento resultam do não envolvimento em atividades físicas adequadas (PESCATELLO \& DiPIETRO, 1993). Essa desatenção se refletirá, em maior ou menor grau, no nível de dependência da pessoa idosa, delimitando principalmente seu grau de independência em realizar as atividades da vida diária. Isto porque, um dos determinantes mais importantes da qualidade de vida para este grupo é sua capacidade para deambulação (MOURA et al., 1999), visto que impedimentos de mobilidade são fortes preditores de mortalidade e dependência entre idosos (VAN DEN HOMBERGH et al., 1995; HIRVENSALO et al.; 2000).

Para DUFFY e MAcDONALD (1990) e WOO (2000), a prática de comportamentos adequados à promoção da saúde por parte da população idosa, especialmente exercícios e nutrição adequada, podem se constituir em fatores criticos para a manutenção da independência pelo maior tempo possível, postergando a necessidade de intervenções por parte do sistema de saúde, já que são fatores que podem retardar o início de processos de incapacitantes.

$\mathrm{Se}$ as pessoas envelhecerem mantendo-se autônomas e independentes, as dificuldades a serem enfrentadas serão reduzidas para eles, a família e a sociedade. A isto denomina-se compressão da morbidade (CHAIMOWICZ, 1997; PASCHOAL, 1997).

Porém, se a sobrevida for acompanhada de agravos crônicos prolongados, com diminuição da capacidade funcional, os problemas gerados serão imensos. Constata-se, então, que a incorporação de 
hábitos de vida saudáveis estão intimamente relacionados à manutenção e restauração da autonomia e independência. Como indicadores de saúde especialmente para a população idosa e para a saúde pública, estes dois aspectos são condições fundamentais para que o idoso mantenha-se como um dos gestores de sua saúde e de sua vida.

\subsection{Modelos de competência}

Um modelo de competência diária foi sugerido por LAWTON (1983). Segundo ele, a literatura disponivel sobre avaliação leva ao consenso de que saúde, saúde funcional, cognição, uso do tempo e comportamentos sociais formam o cenário mínimo para se entender competência de modo ordenado.

Utilizando-se dos aspectos acima, o autor propôs uma hierarquia, colocando-os de forma ordenada e de acordo com a relação e complexidade que possuem entre si, iniciando pela base que é a saúde e finalizando com os comportamentos sociais ou seja, os dominios de comportamentos progridem a partir de um nível mínimo de exigência, sendo que dentro de cada dominio podem ser diferenciados subniveis de complexidade. O autor salienta que não existem instrumentos capazes de discriminar a qualidade do desempenho quando a competência varia do nivel mais baixo para o mais elevado, para cada domínio e nível de complexidade. Contudo, o modelo esquematiza a extensão dos comportamentos que uma medida hipoteticamente ideal deveria incluir, indicando a qualidade do comportamento adaptativo, pré definido por padrões e normas sociais. Assim, todo comportamento é passivel de ser localizado ao longo de uma hierarquia de complexidade e avaliado em termos de sua competência normativa.

Diferente do modelo descrito acima, o modelo de competência sugerido por BALTES e colaboradores (1993) parece ser o que melhor enfoca competência em termos de habilidades necessárias para 
administrar a vida diária, pois utiliza-se de conceitos muito difundidos na literatura, as atividades básicas e atividades instrumentais da vida diária.

De acordo com o modelo, competência é diferenciada em dois componentes: a) competência básica, necessária para a manutenção de uma vida independente, inclui as atividades básicas da vida diária e duas atividades instrumentais da vida diária, a saber, compras e mobilidade e b) competência expandida, referente àquelas atividades que são determinadas pelas preferências individuais, motivos, interesses, incluindo principalmente as atividades de lazer.

O primeiro componente reflete o dominio básico de competência. Inclui duas atividades instrumentais, fazer compras e mobilidade (compreendida como a capacidade de deambulação) justamente por serem, segundo os autores, duas condições indispensáveis para a sobrevivência pessoal.

Já o segundo componente trata de um nivel de competência superior, estendendo-se além do cuidado pessoal, para incluir todas as atividades sociais e de lazer e todas as atividades instrumentais da vida diária (menos compras e mobilidade).

A distinção conceitual entre ambos é que o primeiro relaciona-se à atividades que são rotineiras, habituais, necessárias para sobrevivência ou que são normas para a vida independente de qualquer adulto. Por incorporar atividades que são ditas universais, sobre esse componente recai menor influência de aspectos psicológicos, socioculturais e econômicos ficando mais fortemente sujeito a fatores biológicos ou àqueles relacionados à saúde. O segundo componente, embora seja afetado pelas condições de saúde, destaca-se por ser movido pelas preferências e motivações, indo muito além da mera existência. Sobre ele recai grande influência dos aspectos sociais e comportamentais, como também da idade, cognição, saúde mental e personalidade. Embora a diferenciação conceitual entre os componentes seja necessária, a interdependência entre ambos não deve 
ser ignorada porque, em teoria, a competência básica é o recurso mais importante para a facilitação das atividades de competencia expandida.

Ainda, segundo BALTES e colaboradores (1993), o problema verificado com estudos de competência diária limitam-se a um dos componentes mencionados ou então na relação entre uma caracteristica de competência e um aspecto físico, social ou mental. Contudo, a competência diária é um constructo multidimensional que envolve ampla gama de habilidades individuais organizadas, podendo ser avaliada sob dois aspectos: do ponto de vista da própria habilidade, em termos do dominio da mesma direcionado à autonomia e do ponto de vista de atividades que requerem diversas habilidades, neste caso direcionado ao aspecto da competência adaptativa. Ambos os tipos de avaliação permitem explorar a relação ou distinção entre desempenho de capacidades básicas e o engajamento em atividades mais diversificadas e complexas.

O modelo descrito por BALTES e colaboradores (1993) ganha uma dimensão mais ampla quando analisado em função do uso do tempo pois seria um indicativo dos modos como as pessoas circulam pelo seu próprio ambiente, buscando solucionar suas necessidades e realizar seus objetivos ou seja, os comportamentos observáveis refletiriam a inter-relação entre aspectos biológicos, afetivos e sociais, diferentemente do modelo hierarquizado proposto por LAWTON (1983).

\subsection{Tempo estruturação da vida diária}

Envelhecer é um processo dinâmico no tempo e no espaço.

Todos os dias da vida, toda pessoa interage com objetos, com outras pessoas e com idéias que permeiam seu ambiente. Assim, podese falar em uma ecologia do envelhecimento, um sistema de continua adaptação, no qual o organismo e o ambiente mudam com o tempo, mas não ao acaso, já que o organismo ou o ambiente são capazes de 
iniciarem um ciclo de ação ou de resposta. Portanto, pode-se esperar que, para diferentes competências pessoais e pressão ambiental, obtenha-se como resultado diferentes tipos de comportamentos observáveis (LAWTON \& NAHEMOW, 1973).

Estes ciclos de ação e reação contínuos fazem com que a vida diária seja, em grande parte, heterogênea, sobretudo no que se refere ao conteúdo, significação ou importância das atividades realizadas. Fazem parte da vida diária a organização do trabalho e da vida privada, os lazeres e descanso, atividade social, o intercâmbio e a religiosidade (HELLER, 1985).

Para GOLDSTEIN e SIQUEIRA (2000), a heterogeneidade é um fenômeno que representa as diferenças entre os individuos, em função de suas distintas histórias de vida. Ela é produto da interação entre história pessoal, personalidade e experiências sociais compartilhadas ao longo do tempo.

Apesar da atual riqueza de conhecimento sobre o envelhecimento e a pessoa idosa, muito pouco é conhecido sobre seu cotidiano, como diferentes pessoas em diferentes situações de vida investem seu tempo e como este se apresenta em termos de qualidade das atividades (MOSS \& LAWTON, 1982; VERBRUGE et al., 1996; HORGAS et al., 1998).

A maioria do conhecimento disponível sobre atividades diárias desta população resulta de estudos da área de geriatria, mais especificamente sobre atividades básicas da vida diária e atividades instrumentais da vida diária, a fim de se determinar a necessidade de assistência e o quanto um nível de desempenho se torna insuficiente para uma vida independente (KATZ et al., 1963).

Segundo HORGAS e colaboradores (1998), pessoas selecionam atividades nas quais investirão tempo e atenção a partir de uma ampla variedade de atividades possiveis. A soma destas escolhas retrata o dia vivenciado, um reflexo das prioridades e objetivos imediatos permeados pelo aspecto motivacional. Por outro lado, refletem também 
a medida de oportunidades e impedimentos de natureza variada que podem incentivar ou cercear a participação em certos tipos de atividades como também influenciar na estruturação do dia.

A vida cotidiana, em seu nível mais básico, é regida por três principios universais que formam a base para a participação nas atividades: primeiro, cada pessoa tem apenas 24 horas num dia; segundo, não se pode estar em dois lugares diferentes simultaneamente; terceiro, não hả como mover-se instantaneamente de um lugar a outro. Dessa forma, tempo e espaço representam a influência mais básica interferindo na estruturação das atividades diárias (HANSON \& HANSON, 1993).

Contudo, a vida diária não se limita apenas à dimensão do tempo e espaço. Ela é influenciada pela dimensão social no sentido de que expectativas sociais, normas e padrões também influenciam o modo de escolha das atividades. Em outras palavras, o dia representa uma unidade de tempo, permeada pelos contextos físico (locais de ocorrência das atividades) e social (parceiros sociais), os quais criam oportunidades e restrições para a ocorrência de comportamentos ou atividades.

A repetição constante de atividades num determinado tempo, lugar e contexto podem caracterizá-las como normas comportamentais dentro de um dia considerado típico (BRAUDEL, 1992), sem que isto imprima ao cotidiano um caráter homogêneo.

Como mencionado por HELLER (1985) e GRIGSBY (1996), a heterogeneidade é uma das grandes caracteristicas da atividade diária. Em todos os aspectos da vida, o caráter heterogêneo é decorrente da internalização de comportamentos adquiridos ao longo do processo de desenvolvimento pois o homem nasce inserido num contexto físico e social, interage com os mesmos e deles receberá contínua influência que podem interferir no seu modo de ação. Neste sentido, a heterogeneidade diz respeito às diferenças entre individuos em 
decorrência de suas distintas histórias de vida (GOLDSTEIN \& SIQUEIRA, 2000).

Por outro lado, observa-se que no dia-a-dia adultos e idosos, ao fazerem escolhas adaptativas, tentam preservar e manter as estruturas internas e externas fazendo uso de estratégias, duas delas conceitualmente denominadas continuidade e adaptabilidade.

A continuidade, uma teoria postulada por ATCHLEY (1989), estabelece que estes individuos são impelidos, pelo peso das experiências passadas, a usarem a continuidade como estratégia adaptativa para tratar com as mudanças associadas ao envelhecimento normal. Mas, continuidade não é o oposto de mudança. Em realidade, continuidade é um constructo cognitivo abstrato que significa coerência ou consistência de modelos em relação ao tempo. Isto porque, durante a existência, uma infinidade de episódios ocorrem sem causarem desequilíbrios substanciais ao indivíduo. A habilidade de mover-se e interagir com seu meio permite ao individuo determinar a natureza e grau dos estímulos que recebe e esta infinidade de experiências vivenciadas dentro de inúmeros contextos, quando são incorporadas, tornam-se parte do acervo de novas estratégias disponiveis. Portanto, a continuidade é fruto da utilização de formas variadas de estratégias de enfrentamento da realidade, que foram aprendidas e incorporadas pela pessoa ao longo do tempo, com a finalidade de manter um padrão de competência estável ao longo do processo de envelhecimento. Esse padrão de competência estável pode ser comparado à habilidade necessária para que o individuo se adapte adequadamente ao seu ambiente.

Adaptabilidade é o conceito chave da teoria ecológica do envelhecimento proposta por Lawton e Nahemow, em 1973 (NAHEMOW, 2000), onde uma das questões principais é se o individuo possui a habilidade necessária para desempenhar determinadas tarefas, independente do quão bem ele possa desempenhá-la ou executá-la em niveis ideais. Pessoas idosas 
requerem um tempo maior para alcançar adaptação e reestruturação adequada quando um fato novo se apresenta, sendo este tempo relacionado ao nivel de competência individual. Portanto, a pressão ambiental, aliada ao nível de competência, é que determinarão o nível de adaptação individual que deve ser visto não como um ponto fixo a ser atingido, mas como tendo inúmeras gradações que oscilam, tanto negativamente quanto positivamente, ao redor deste mesmo ponto.

A estruturação dos comportamentos observados no dia-a dia também podem ser analisados como pertencentes à grupos de atividades que guardam determinada relação entre si ou então pelo grau de necessidade de execução de determinadas atividades.

Segundo CSIKSZENTMIHALYI (1999), em geral, todas as atividades humanas observáveis podem ser agrupadas como ocorrendo em três grupos principais de atividades. O primeiro e maior deles inclui todas as atividades produtivas que são necessárias para gerar energia para a sobrevivência e conforto. Para o adulto, isto pode ser sinônimo de "ganhar dinheiro" e, para o adolescente, o aprendizado pode ser incluido na categoria produtiva porque, para os mesmos, educação eqüivale a trabalho no futuro. O segundo grupo inclui as atividades de manutenção, tanto aquelas dedicadas ao cuidado com o corpo, como aquelas relacionadas com a manutenção e organização das posses materiais. O tempo restante é o tempo livre ou lazer e se constitui no terceiro grupo.

Em outro ponto de vista, teórico, classifica-se as atividades diárias em atividades obrigatórias e atividades discrecionárias (MOSS \& LAWTON, 1982; HORGAS et al., 1998).

Atividades obrigatórias são aquelas necessárias para a sobrevivência pessoal recaindo sobre elas maior teor restritivo do que opções de escolha. No campo geriátrico muitas vezes são denominadas atividades básicas da vida diária (KATZ et al., 1963) e atividades instrumentais da vida diária (LAWTON \& BRODY, 1969). Atividades relacionadas à sobrevivência como banhar-se, vestir-se, alimentar-se 
(atividades básicas) e atividades relacionadas à adaptação ao meio como usar telefone, cozinhar, fazer compras e administrar as próprias finanças (atividades instrumentais) são consideradas fundamentais para uma vida independente. Em conjunto, este grupo inclui atividades rotineiras, familiares, constituindo-se em hábitos necessários para a sobrevivência e, portanto, universais. Esta universalidade implica em poucas diferenças individuais mesmo em relação a vários fatores como o cultural e econômico. O aspecto motivacional, de oportunidades e culturais também interferem nos modos de desempenho destas tarefas. Contudo, tais influências são mais relevantes para com as atividades instrumentais, onde a habilidade de execução é avaliada pelo desempenho em relação ao ambiente real, principalmente para o idoso, ao invés de um conjunto previamente estabelecido e desejado de habilidades ou comportamentos observáveis.

Já as atividades discrecionárias são aquelas escolhidas pela pessoa e que envolvem afeto, conhecimento, prazer e interesse, sofrendo, portanto, grande influência de inúmeros fatores individuais (LAWTON et al., 1987).

Para BALTES e colaboradores (1993), atividades discrecionárias eqüivalem a um componente de competência diária, especificamente competência expandida, o qual exige um nível básico de cognição e domínio de conhecimentos específicos para a solução de problemas que se apresentam diariamente.

A escolha de atividades dentro destas duas categorias pode ser influenciada pela saúde do individuo, pelas oportunidades ou restrições impostas pelo meio social ou seja, idade, grau de instrução, renda, estado civil, dentre outros e também o próprio ambiente (BRANCH et al., 1989).

MEDEIROS (1994), em um trabalho sobre saúde e qualidade de vida em idosos, constatou que as afecções dos órgãos que interferem nas inter-relações pessoais (audição, visão e locomoção) foram os 
principais fatores de limitação do convivio social e mesmo familiar entre os individuos estudados.

Por outro lado, a Organização Mundial da Saúde (1993) destaca que as motivações sociais complexas se constituem, com freqüencia, nos determinantes mais importantes do comportamento cotidiano em relação às necessidades básicas ou seja, as diferenças na realização das atividades humanas podem estar mais relacionadas ao grau de motivação individual do que com a competència intelectual ou física.

Segundo CARP (1978), um meio ambiente com ampla gama de oportunidades faz com que o idoso se envolva num maior número de atividades e que intervenções ambientais são fatores potentes para influenciar a aquisição de novos comportamentos, mesmo em idades avançadas.

GRIMLEY-EVANS (1984) menciona que, entre pessoas vivendo em diferentes ambientes e com estilos de vida também diferentes, vários agravos e incapacidades apresentados pelos idosos não são resultados de fatores biológicos e/ou genéticos, mas de fatores sócioeconômicos e culturais. Sem dúvida, uma abordagem mais qualitativa atribuindo mais importância às características sociais, culturais e econômicas dos idosos é fundamental para se compreender melhor os comportamentos diários observáveis desta população.

Assim, pode-se inferir que a execução de atividades obrigatórias e discrecionárias também estão relacionados às fontes de inteligència disponiveis ou seja, inteligência fluída e cristalizada (BALTES, 1993). Juntas, podem atuar como barreiras ou facilitadores do grau de participação nas atividades cotidianas.

Estudos sobre a realização de atividades entre pessoas idosas têm demonstrando que, em relação a individuos mais jovens, os primeiros consomem a maior porcentagem do dia na execução de atividades básicas e instrumentais e menos tempo em repouso e atividades complexas (ASHWORTH et al., 1994), uma clara alusão ao conceito de mudanças funcionais associada ao envelhecimento. 
Estudo de BALTES e colaboradores (1990) mostraram que o perfil típico de atividades é caracterizado, em termos de maior freqüência, pela realização de atividades obrigatórias mas que o tempo gasto na sua realização ocupa apenas parte do dia, predominantemente as manhãs. Também os niveis de atividades realizadas no ambiente interno (doméstico) e externo (social) mostram um marcado declínio com a idade, onde o papel do gênero exerce uma forte influência nos niveis e tipos de atividades habituais.

Segundo BENNETT (1998), mulheres idosas mostram uma proporção maior de atividades realizadas no ambiente doméstico, sendo que o oposto se verifica com os homens. Isto, provavelmente, pode ser um dos reflexos do papel social imposto à mulher pelo casamento ou como norma convencional, em que à mulher cabe o papel de cuidar da casa e dos filhos e ao homem o de mantenedor da familia, necessitando, portanto, continuamente ausentar-se do lar.

Para BALTES e colaboradores (1990), a maior proporção de atividades realizadas no ambiente doméstico faz deste o domínio geográfico mais importante da vida diária do idoso. É nele também que se processa a maior parte da atividade de lazer destes individuos, assistir televisão (HORGAS et al., 1998).

Para ALBERT (2000), o uso do tempo mostra os diferentes modos de utilização do ambiente por parte das pessoas, constituindose numa medida de espaço psicológico e social. Para trafegar livremente pelo ambiente e engajar-se em inúmeras atividades, uma boa condição de saúde se faz necessária. Deste modo, o uso do tempo também pode refletir um estado de saúde já que esta pode limitar e mesmo alterar as proporções do dia gastos em diversas tarefas bem como a utilização do espaço físico.

Já MOSS e LAWTON (1982) avaliaram o uso do tempo como um indicador de competência comportamental e bem-estar psicológico levando em consideração os efeitos das limitações funcionais. Para eles, a alocação do tempo que é, acima de tudo, como o indivíduo 
utiliza seu tempo, possui uma variedade de determinantes, incluindo as oportunidades ambientais, personalidade, eventos particulares que podem ocorrer ocasionalmente e saúde funcional. Deste modo, os autores consideram o uso do tempo como um indicador de estilo de vida.

Portanto, a descrição da estruturação da vida diária da pessoa idosa em função do uso tempo e a influência de outras variáveis (idade, sexo, escolaridade, renda, por exemplo) sobre o engajamento em atividades, fornece um primeiro vislumbre sobre a competencia diária destes individuos, reflete diferenças em termos de estilos de vida e pode fornecer a chave para aumento na qualidade de vida desta população, na medida em que aponta para possíveis áreas que demandem necessidade de intervenção (MOSS \& LAWTON, 1982).

\subsection{Estudos sobre uso do tempo com população idosa}

Resultados de estudos de uso do tempo com pessoas idosas podem ser utilizados para verificar o modo de vida de diferentes grupos, diferentes idades, etnias, de individuos com deficiências especificas, de mudanças comportamentais e de saúde ao longo do tempo, de adaptações frente ao processo da aposentadoria e da continuidade do trabalho após a chegada da mesma, dentre outros.

UJIMOTO (1990) salienta que estudos dessa natureza podem captar mudanças nos modelos de atividade ao longo do tempo, gerando informações valiosas sobre o bem estar da pessoa, podendo ser úteis no desenvolvimento de ambientes sociais adequados. O autor também indica estudar o uso do tempo com cuidadores formais e informais com o intuito de assegurar uma melhora contínua dos serviços prestados por esses profissionais e também das relações entre cuidador e idoso.

Uma forma de coleta de dados sobre as atividades diárias de idosos consiste na aplicação de um questionário estruturado, administrado em intervalos específicos. Em geral, tais perguntas reportam-se à capacidade para executar atividades básicas e 
instrumentais, necessárias para um viver independente, com o intuito de verificar alterações no padrão de desempenho ao longo do tempo. Este tipo de instrumento restringe as informações sobre o cotidiano da pessoa idosa, ao revelar apenas desempenhos em segmentos especificos do dia-a-dia, embora tenham o mérito da praticidade para obtenção dos dados.

Como mencionado anteriormente, estudos sobre as atividades de idosos tem demonstrando que, quanto ao tipo de atividade, estes consomem maior tempo do dia efetivo na execução de atividades básicas e instrumentais e menos tempo em repouso e atividades complexas, quando comparados com individuos mais jovens (ASHWORTH et al., 1994).

Estudo de BALTES e colaboradores (1990) mostraram que o perfil típico de atividades é caracterizado, em termos de maior freqüência, pela realização de atividades obrigatórias mas que o tempo gasto na realização das mesmas ocupa apenas parte do dia, predominantemente as manhãs. Mostraram também, que os níveis de atividades realizadas no ambiente interno (doméstico) e externo (social) evidenciam um declínio com a idade.

Os resultados de VERBRUGGE e colaboradores (1996), obtidos através de aplicação de questionários aos participantes do Baltimore Longitudinal Study of Aging, no periodo de 1958 a 1992, também evidenciaram um aumento das atividades obrigatórias e lazer passivo (assistir televisão) ao longo dos anos. Também constatou-se um aumento do tempo consumido no trabalho remunerado e diminuição do tempo gasto em atividades domésticas para o sexo feminino, sendo que o inverso foi observado para o sexo masculino, uma clara alusão à mudança no papel social das mulheres que cada vez mais tende a se intensificar.

Segundo BENNETT (1998), mulheres idosas ainda mostram uma proporção maior de atividades realizadas no ambiente doméstico sendo que o oposto se verifica com os homens, mostrando a influência do 
gênero na distribuição das atividades em relação ao contexto físico do idoso.

Para BALTES e colaboradores (1990), a maior proporção de atividades realizadas no ambiente doméstico torna este espaço o domínio geográfico por excelência na vida diária das pessoas idosas.

O desempenho nas atividades diárias parece estar associado à idade, nivel sócioeconòmico, estado civil, incapacidades, presença de doenças crônicas, condições de moradia e infra-estrutura (VAAN DEN HOMBERGH et al., 1995). Todos estes aspectos podem influir, em graus variados, na escolha das atividades e, por conseguinte, no nível de competência desta população.

São poucos os estudos realizados que buscam conhecer o uso do tempo com individuos idosos, utilizando-se das classificações internacionais já descritas ou então de escalas similares. Todos foram realizados no exterior, especialmente nas sociedades onde o fenômeno do envelhecimento já está devidamente incorporado, com o intuito de verificar o modo de vida, tendências e o próprio processo de envelhecimento desta população.

O método de coleta de dados com esta clientela não é isenta de problemas. Um dos meios de coleta de informações em pesquisas de uso de tempo é a utilização de um diário, onde o individuo anota todas as atividades realizadas no dia ou então é realizado um recordatório (entrevista) com a mesma finalidade.

O processo de envelhecimento impõe, muitas vezes, alterações cognitivas ou incapacidades que se traduzem em problemas para anotar e/ou recordar, de modo eficiente, tudo o que foi vivenciado num determinado dia. Este problema pode tornar-se mais agudo com a idade. Além disso, a anotação pode restringir-se àquelas atividades que foram mais significativas, perdendo-se muito do conteúdo diário. Dessa forma, com a população idosa, utiliza-se mais as entrevistas, onde o pesquisador pode intervir procurando auxiliar no processo recordatório. A presença de um cuidador também pode ajudar a 
reconstituir o dia vivido. Paralelamente, obtém-se outras informações pessoais do entrevistado que podem ser relevantes para compor o universo da população estudada.

Como mencionado, o estudo do uso do tempo constitui-se numa medida do espaço psicológico e social além de refletir o estado de saúde individual. Porém, muitas atividades realizadas diariamente possuem pouca ou nenhuma relação com o quesito saúde. Por esse motivo MOSS e LAWTON (1982) foram os primeiros a avaliar o uso do tempo como indicador de comportamento ou seja, indicador de estilo de vida.

No trabalho realizado pelos autores, foram avaliados 535 idosos (homens e mulheres; idade média de 76 anos) distribuidos em quatro grupos (idosos independentes residentes na comunidade; residentes na comunidade e aguardando para transferirem-se para instituições públicas; residentes em instituições públicas e idosos recebendo suporte social ou de saúde à domicílio), representando quatro estilos de vida diferentes. Os resultados evidenciaram padrões similares de atividades diárias exibidas pelos quatro grupos, especialmente na quantidade de tempo gasto nos vários contextos sociais analisados e na realização de uma maior quantidade de atividades obrigatórias. Detectou-se também como os diferentes tipos de ambiente e características pessoais imprimem diferenças no modo de utilização do tempo. Em especial, idosos independentes e residentes na comunidade permaneciam a maior parte do tempo sozinhos em casa, tendo como atividade de lazer predominante assistir televisão.

HORGAS e colaboradores (1998) avaliaram 516 idosos (idades 70 a 105 anos) e encontraram entre eles uma alta frequência na realização de atividades obrigatórias realizadas estando eles sozinhos. Também evidenciaram um tempo substancial destinado às atividades discrecionárias. Novamente, assistir televisão foi a atividade de lazer mais predominante e o espaço físico predominante foi a casa. 
Tanto MOSS e LAWTON (1982) como HORGAS e colaboradores (1998) elaboraram suas próprias classificações de atividades diárias, provavelmente levando em consideração o conhecimento que dispunham sobre o perfil da população idosa a ser avaliada.

Estudo de GAUTHIER \& SMEEDING (2000) examinou os modelos de uso do tempo de adultos (55 a 64 anos), utilizando os resultados de pesquisas de uso do tempo conduzidas por seis países (Áustria, Canadá, Finlândia, Itália, Suécia e Estados Unidos).

O objetivo do estudo foi comparar o uso do tempo em relação ao sexo e trabalho ou seja, de que forma ocorria a transição entre trabalho e aposentadoria para homens e mulheres e de que forma esta transição se evidenciava na realocação do tempo. Apesar das diferenças culturais em termos do momento de ocorrência da aposentadoria, os resultados mostraram que o modelo de uso do tempo dos aposentados destes paises assemelhava-se aos dias de folga de pessoas ainda ativas. Segundo os autores, este achado concorda com os pressupostos da teoria da continuidade ou seja, não há evidência de que a transição entre trabalho e aposentadoria induza à uma mudança radical nos modelos de uso do tempo. Ao contrário, pessoas parecem adotar os modelos dos dias de folga, quando ainda exerciam trabalho remunerado. Quanto ao gênero, há evidências de que a transição entre trabalho e aposentadoria encontre convergência nos modelos de uso do tempo entre homens e mulheres apenas nos Estados Unidos, Canadá e Finlândia. Apesar destes achados, mencionam que o envelhecimento fisiológico poderá introduzir um processo de descontinuidade nos modelos de uso do tempo em idades mais avançadas.

Esta última proposição encontra respaldo nos achados de ONDER e colaboradores (2002) que verificaram, a partir de testes clínicos em idosas a partir de 65 anos, um declinio de 16 a $27 \%$ na performance de membros inferiores e de 7 a $24 \%$ em membros superiores, num intervalo de três anos. Este declinio tem um efeito 
direto sobre a capacidade de deambulação destas pessoas, com conseqüente alteração do padrão de execução das atividades diárias.

\subsection{Estilo de vida}

$\mathrm{Na}$ busca de caminhos que levem à um envelhecimento bem sucedido, estudos mostram que a adoção de um estilo de vida saudável pode ter um importante papel no aparecimento e controle de doenças, principalmente crônicas.

Aspectos como dieta, atividade física e tabagismo são apontados como os principais fatores a serem observados na prevenção de condições debilitantes que afetam pessoas idosas (WOO, 2000; IWASAKI et al., 2001; HUBERT et al., 2002). Portanto, intervenções no estilo de vida são, em geral, primeiramente direcionadas aos fatores que reduzam o risco de morte prematura, com o intuito de aumentar a expectativa de vida.

O crescente número de pessoas idosas e o aumento da longevidade aumentaram a preocupação com a qualidade de vida desta população. Atualmente, assuntos relacionados ao bem estar físico, psicológico e social estão entre as prioridades das politicas de saúde, educação, trabalho e seguridade social voltadas às pessoas idosas (NERI, 2001)

Estilo de vida e qualidade de vida muitas vezes são empregados como sinônimos porém, cada um tem sua própria definição.

Qualidade de vida é um termo técnico, que implica obter informações quantitativas que devem expressar em números os resultados de ações ou que forneçam referenciais para comparação. Para esse fim utiliza-se indicadores ou índices, números que procuram descrever um determinado aspecto da realidade ou uma relação entre vários aspectos. São exemplos de indicadores de qualidade de vida renda, habitação, abastecimento de água, coleta de lixo, esgoto, transporte, alfabetização, mortalidade infantil e número de leitos 
hospitalares. São, portanto, critérios objetivos facilmente verificáveis.

Contudo, o grupo de qualidade de vida da Organização Mundial da Saúde (1994) citado por FLECK e colaboradores (2000), definiu qualidade de vida como "a percepção do individuo de sua posição na vida no contexto da cultura e sistema de valores nos quais ele vive e em relação aos seus objetivos, expectativas, padrões e preocupações". Tal definição deixa implicito que se trata de um constructo subjetivo, multidimensional, incluindo elementos de avaliação positivos e negativos.

De acordo com NERI (2001), qualidade de vida é um evento multideterminado, com múltiplos dominios, cuja avaliação, que tem como referencial vários critérios, consiste na comparação de condições existentes com aquelas desejáveis.

Instrumentos para avaliar qualidade de vida podem apresentar várias dimensões (psicológica, física, nível de independência, relações sociais, ambiente e espiritualidade, por exemplo), cada uma delas composta por facetas avaliadas através de questões. Os resultados são expressos não somente através de indices de desenvolvimento, mas também de bem-estar, satisfação, desejabilidade ou perspectiva de futuro. Isto porque, valores e expectativas individuais podem afetar o modo como a pessoa se vê dentro do seu contexto de vida.

LAWTON (1983) propôs um modelo de qualidade de vida na velhice, estruturado em quatro dimensões (comportamental, ambiental, qualidade de vida percebida e bem estar subjetivo) que cobrem critérios socionormativos e intrapessoais, levando em conta as relações presentes, passadas e prospectivas entre a pessoa idosa e seu ambiente. Destaca-se aqui a dimensão comportamental, que se refere à avaliação do funcionamento individual em relação à saúde, funcionalidade física, cognição, comportamento social e utilização do tempo, objeto de estudo deste trabalho. 
Faz-se importante ressaltar o ganho em qualidade de vida que a humanidade conquistou com a revolução industrial e, posteriormente, com a tecnológica. Ambas resultaram num aumento do tempo livre que é ocupado, em sua grande maioria, com estratégias aliciantes de entretenimento que reforçam um estilo de vida sedentário, característico das sociedades desenvolvidas.

Com relação ao estilo de vida, AMARAL (1992) o define como a forma pela qual uma pessoa ou grupo vivencia o mundo e, consequentemente, se comporta e faz escolhas.

Para BOURDIEU (1983), o que caracteriza os elementos que compõem o estilo de vida é a distância destes elementos em relação às necessidades básicas da pessoa ou grupo. Por exemplo, se comer é uma necessidade básica, o modo como se come, tipo de comida, uso e tipo de talher indicam valores que constituem estratégias de distinção no meio social. Assim, segundo o autor, quanto maior a distância em relação às necessidades básicas, o estilo de vida torna-se mais e mais um produto de uma "estilização da vida" que orienta e organiza as mais diversas práticas, como o tipo de roupa, decoração, religião, tipos de lazer e comportamentos.

Essa "estilização da vida" parece ser, simultaneamente, fator de agrupamento e também instrumento para desenvolvimento de limites, formas de comunicação e outros mecanismos necessários à organização de um grupo, conferindo ao mesmo uma identidade.

Definições à parte, verifica-se que tais conceitos estão relacionados e interferem diretamente, de forma positiva ou negativa, em todas as fases do desenvolvimento humano.

Em se tratando do envelhecimento, pode-se inferir que características genéticas juntamente com condições ligadas à qualidade de vida influenciam o estilo de vida da pessoa idosa. Por sua vez, o estilo de vida interfere no processo de envelhecimento orgânico e este último, em contrapartida, provoca alterações no estilo de vida. 
O grau com o qual mudanças no estilo de vida poderiam aumentar a longevidade foi verificado por HUBERT e colaboradores (2002), ao testarem a hipótese da compressão da morbidade, proposta por FRIES (1980). Num estudo longitudinal (1986-1998), os autores verificaram que pessoas idosas que não apresentavam os fatores de risco considerados pelo estudo (fumo, sedentarismo e peso acima ou abaixo do ideal), apresentavam um valor médio para incapacidades próximo a zero, por um periodo de 10 a 12 anos, antes de virem a óbito. Para aqueles que possuiam a presença de algum fator de risco, a taxa de declínio aumentou significativamente somente nos últimos três meses antes do falecimento.

ROSE (1992) salienta que a ocorrência de grande número de doenças e agravos a que as pessoas estão sujeitas guarda relação direta com o que elas comem e bebem, com suas atividades diárias, seu ambiente físico e social.

A partir da colocação acima, a interação social também passa a ser um fator importante do estilo de vida na medida em que guarda relação com a satisfação e o bem estar da pessoa.

Baixos níveis de engajamento social podem ser considerados precursores importantes de mortalidade entre idosos (BENNETT, 2002).

Individuos socialmente isolados apresentam taxas de suicídio significativamente maiores, maior número de impedimentos físicos e cognitivos e uma menor expectativa de vida quando comparado com pessoas idosas socialmente mais ativas (TSIRAKIS, 1999).

Um estilo de vida mais ativo e saudável na velhice pode levar a um processo de "desaceleração" do envelhecimento fisiológico, condição esta necessária para um envelhecimento bem sucedido, conforme proposto por ROWE e KAHN (1987) e por um desempenho adequado na dimensão comportamental, conforme modelo de qualidade de vida proposto por LAWTON (1983). 
O estilo de vida de um grupo ou população idosa pode ser evidenciado através do estudo do uso do tempo, pois este permite conhecer o grau de participação das pessoas nos diferentes dominios comportamentais. Estes achados tem implicações importantes no âmbito das ações públicas multissetoriais e da prática multidisciplinar na medida em que atuarão no sentido de eliminar ou reduzir as barreiras que impedem um maior envolvimento da pessoa idosa para com a vida e com seu meio. Além disso, os resultados podem contribuir para a criação de programas especificos, visando aumentar a capacidade funcional, diminuindo o risco de institucionalização e, talvez, aumentando a longevidade.

O perfil do estilo de vida de uma população também pode contribuir para a atenção de saúde primária da mesma. Para o cumprimento deste objetivo, é necessário a deteç̧ão e prevenção precoce de agravos em áreas comportamentais distintas, demandando as intervenções necessárias, bem como esforços para reabilitar a pessoa e a comunidade, para melhor cuidarem da saude, detectarem problemas e enfrentá-los com enfoques menos dispendiosos e mais efetivos (Organização Panamericana de Saúde 2002).

\subsection{A feminização do envelhecimento: breves considerações}

Trata-se de tendência mundial o fato de mulheres responderem pela maioria da população idosa, constituindo-se, também, no grupo predominante nas faixas etárias mais avançadas (WHO, 1999).

Em geral, mais da metade dos idosos na faixa etária de 60 a 69 anos são do sexo feminino e também mais de $65 \%$ dos idosos na faixa dos 80 anos e mais são mulheres, um quadro com tendência crescente para ambas as situações.

No Brasil, como na grande maioria dos países, o aumento na expectativa de vida ao nascer tem sido mais significativo no sexo feminino. Segundo a Fundação IBGE (2001), no Brasil, a proporção de idosos acima de 80 anos pode variar de $9 \%$ a $11,3 \%$ entre 1995 e 2020 e, dentre os idosos acima de 70 anos, $39,6 \%$ do total são mulheres. 
A Fundação SEADE, já em 1999, estimava que, para um contingente de 35,1 milhões de pessoas vivendo no estado de São Paulo, 2.954.482 possuiam 60 anos ou mais, evidenciando uma proporção de idosos de $8,4 \%$. Para o município de São Paulo, esta proporção representava $8,9 \%$.

Segundo CHAIMOWICZ (1998), desde os anos sessenta as taxas de crescimento da população idosa feminina (3,9\% entre 1980 e 1991) tem sido superiores às da masculina para a mesma idade $(3,4 \%$ no período).

O predomínio de mulheres ocorre por uma série de motivos biológicos, culturais e comportamentais. Evidencias sugerem aspectos genéticos e hormonais como parte da diferenciação. São apontados alguns aspectos criticos que podem estar relacionados com a predominância do sexo feminino em relação ao masculino: maior proteção cardiovascular dada pelos hormônios femininos, menor exposição aos riscos de trabalho, condutas menos agressivas, maior atenção em relação ao aparecimento de doenças e melhor conhecimento destas, menor envolvimento em atividades físicas extenuantes, menor aderência em relação a hábitos nocivos como fumo e álcool e maior utilização de serviços de saúde. Um outro fator refere-se aos avanços na assistência médico-obstétrica que possibilitou uma queda na mortalidade de parturientes (HUYCK, 1990; RAHMAN et al., 1994).

Aumento na expectativa de vida de idosos, sobretudo das mulheres, é um fenomeno recente que gera muitas implicações sociais, dentre eles a emergência de famílias multigeracionais, alta taxa de viuvez, alta prevalência de doenças crônicas e distúrbios psiquiátricos e também vários niveis de dependência física (WHO, 1984; RAMOS et al., 1998).

$O$ fato de habitar um ambiente multigeracional possibilita à mulher idosa desempenhar o papel de cuidadora para outras pessoas, tanto do círculo familiar como para terceiros por uma série de razões, 
embora o papel de cuidadora seja exercido, sobretudo, em relação ao marido. Assim, o cuidado com os outros pode ser visto como mais um tipo de trabalho desgastante e não remunerado que pode levar tais mulheres a se deparar com problemas de saúde física e mental (GOLDANI, 1999).

Outro aspecto importante refere-se ao poder aquisitivo desta população, onde aposentadorias e pensões são a principal fonte de rendimentos. Segundo CHAIMOWICZ (1998), 1/3 dos brasileiros com 60 anos ou mais mantém-se em atividades produtivas. Porém, a permanência no mercado de trabalho dá-se, sobretudo, no mercado informal, em atividades mal remuneradas e em jornadas extensas, onde a renda é inferior ou igual a dois salários minimos, conseguidos com o exercício de atividades pouco compativeis com a faixa etária como serventes e serviços de pedreiro para os homens e empregadas domésticas, passadeiras e lavadeiras para as mulheres. Indicações do IBGE (1995) já mostravam que, entre indivíduos com mais de 60 anos, $48,5 \%$ dos homens trabalhavam e, para as mulheres, esse percentual era de apenas $20,2 \%$, um reflexo da precariedade da renda deste grupo.

A mulher é muito mais solitária na velhice em relação ao homem. Isto porque, além de viver mais, casa-se mais jovem e, uma vez viúva, apresenta menor taxa de segundo casamento que o homem viúvo, o que pode gerar implicações na assistência e cuidado às mesmas, quando diante de um possível estado de fragilidade. Para muitas mulheres, a viuvez caracteriza-se por ser a maior perda na idade avançada, um estado que pode vir acompanhado de declínio pessoal em todos os aspectos (WHO, 1999).

$O$ aumento da expectativa de vida para a mulher implica em atenção na qualidade de vida deste grupo, principalmente em idades mais avançadas, em todas as sociedades.

Para tanto, a Organização Mundial da Saúde (1999) preconiza três pontos importantes a serem considerados. O primeiro diz respeito 
à prevalência de enfermidades, que é maior em mulheres mais idosas em relação às mais jovens. O impacto na saúde, que também é maior para as mais idosas em relação aos homens, pode, potencialmente, alterar ou limitar o papel social da mulher. Em segundo lugar, deve-se atentar para o impacto progressivo destes problemas sobre o funcionamento, independência e mortalidade deste grupo. Embora vivam mais, parte da longevidade conquistada pode ser vivida em algum eștado de dependência Neste sentido, incentivar medidas de prevenção e promoção de saúde são fundamentais. Por último, faz-se necessário atentar para que os problemas de saúde apresentados sejam convenientemente identificados e tratados, pois tem sido grande o número de diagnósticos equivocados que levam a tratamentos ou intervenções incorretas, com grave prejuizo ao paciente.

Segundo a Organização Panamericana de Saúde (1994), as mulheres devem receber atenção especial das politicas de saúde pois, na atualidade, o que se observa é que muitas das necessidades dos mais velhos são, em realidade, necessidades das mulheres.

Para a American Geriatrics Society (1993), as pesquisas deveriam concentrar-se em examinar a saúde da mulher além da tradicional esfera biomédica, considerando a complexidade, dimensões e circunstâncias naturais da vida deste grupo, uma atitude que em muito auxiliaria conhecer quando há necessidade de intervenções em tempo de se evitar a instalação de agravos maiores e possibilitar a sobrevivência em idades mais avançadas de modo mais independente possivel.

Além dos aspectos acima, a Organização Mundial da Saúde (1998) salienta que o grande contingente de mulheres idosas em breve estará vivendo em países em desenvolvimento, cujas caracteristicas econômicas, sociais, políticas e culturais são muito diferentes daquelas de paises desenvolvidos. Assim, já se constata que as transformações nos papéis sociais de idosas vivendo em paises em desenvolvimento estão ocorrendo de forma mais rápida em relação aos 
paises desenvolvidos, uma evidência clara de que este grupo vêm aumentando sua participação na força de trabalho, sobretudo no trabalho informal.

Portanto, o aumento da expectativa de vida da mulher em paralelo às transformações do seu papel na sociedade, requerem atenção imediata já que neste grupo, perdas cumulativas (por exemplo viuvez, menor renda, maior número de doenças crônicas) interferem significativamente na sua qualidade de vida. 


\section{OBJETIVO}

A implementação de politicas e estratégias visando o envelhecimento satisfatório da pessoa idosa somente será efetiva se houver o conhecimento da realidade cotidiana desta população.

Assim, o objetivo deste estudo é descrever como um grupo de mulheres idosas utiliza o tempo para realização de suas atividades diárias quanto a:

- grupos de atividades principais;

- contexto físico (locais) das atividades;

- contexto social (parceiros sociais) das atividades;

- atividades secundárias;

- tipos de trabalho realizado;

- tipos de atividades de lazer. 


\section{MÉTODO}

\subsection{Tipo de pesquisa}

Trata-se de um estudo descritivo sobre a utilização do tempo por um grupo de mulheres idosas, pertencentes a um grupo de convivência.

Estudos descritivos têm como objetivos, dentre outros, mostrar características de determinada situação, individuo, grupo ou então verificar a freqüencia de ocorrência de determinado evento e, enquanto pesquisa, podem também apresentar elementos de funções caracteristicas de outros tipos de estudo (SELLTIZ et al., 1967).

Assim, alguns estudos, embora descritivos, prestam-se mais ao esclarecimento de novas nuances do problema, aproximando-se dos estudos exploratórios (GIL, 1987)

\subsection{População e amostra}

O estudo foi realizado na cidade de Rio Claro, interior de São Paulo, no mês de julho de 2002, com um grupo de idosas, idades de 60 anos e mais, pertencentes a um grupo de convivência, que se reúne às segundas feiras, no horário das 14.00 às $17.00 \mathrm{~h}$, num espaço da prefeitura. Além das idosas participantes no estudo, também congrega mulheres mais jovens, totalizando 47 pessoas. A atividade principal (e absoluta na preferência) resume-se a um bingo, onde são angariados fundos para pagamento de algumas viagens feitas pelo grupo. Ao final de cada encontro é servido um chá. Atividades culturais são esporádicas. A coordenação do grupo está a cargo de duas voluntárias. O grupo não possui qualquer vínculo com o poder municipal tendo se organizado voluntariamente.

Não existem critérios específicos para participação mas, em geral, as participantes possuem 50 e mais anos, residem no mesmo bairro onde são realizados os encontros, não havendo limite de vaga.

O grupo foi contatado durante uma de suas reuniões, onde foi exposto o objetivo do estudo bem como a utilização dos instrumentos 
de pesquisa. Todas as dúvidas apresentadas foram devidamente esclarecidas, enfatizando-se o caráter totalmente voluntário da participação. Mencionou-se também a intenção de publicar os resultados, guardando total sigilo quanto às informações prestadas. Ficou estabelecido que, para as que concordassem em participar, a continuidade do estudo seria realizada no próprio domićlio, em conversa reservada, conforme disponibilidade de dia e horário da interessada.

Neste dia, seriam aplicados todos os instrumentos de pesquisa necessários para levantamento das informações, na seguinte ordem: teste de cognição, folha de registro de dados pessoais e entrevista estruturada.

Todas foram informadas quanto à necessidade de formalização da participação, feita através do Termo de Consentimento (ANEXO I), que seria também assinado no dia da entrevista.

Ao final do encontro, as interessadas já deixaram agendadas com uma das responsáveis do grupo, datas e horários para entrevistas.

Do total de 47 senhoras que integram o grupo, 08 tinham 59 anos ou menos, sendo, portanto, descartadas; 14 recusaram-se e 25 consentiram em participar.

Portanto, obteve-se uma amostra não probabilistica, selecionada pelo critério de conveniência (ou melhor condição de acessibilidade) (POLIT, 1989), constituida de 25 idosas, distribuidas nas seguintes faixas etárias: 18 mulheres entre 60 e 70 anos, 5 mulheres entre 71 e 80 anos e 2 mulheres acima de 80 anos.

\subsection{Critério de participação}

Estritamente para a finalidade deste trabalho, constituiram a amostra mulheres fisicamente independentes, participantes de um grupo de convivência, com 60 anos e mais e com função cognitiva preservada, avaliada através do Clock Completion Test (descrito posteriormente). 
A definição da faixa etária foi baseada no critério cronológico, conforme adotado no Brasil e respaldada pela Lei $N^{0} 8.842 / 94$, que considera idoso indivíduos com 60 anos de idade ou mais (PACHECO, 1997).

A presença de doenças crônicas não foram consideradas, uma vez que idosos podem adaptar-se às mesmas podendo levar uma vida autônoma e independente (FERRARI, 1999; KIRKWOOD, 2000).

\subsection{Coleta de dados}

Para as participantes, no dia da entrevista individual previamente agendada, foram aplicados na coleta de dados e, pela ordem, os seguintes procedimentos:

- Clock Completion Test, aplicado para avaliar a capacidade cognitiva (ANEXO II), sendo os scores do teste utilizados como critério de inclusão/exclusão para participação no estudo;

- Registro de dados pessoais (ANEXO IV), utilizado para obter informações individuais para melhor caracterização da amostra;

- Time Diary, conforme proposto pelo Australian Bureau of Statistics (1992; citado por STINSON, 1999; ANEXOS V e VI), para registrar as atividades diárias recordadas.

Para facilitar a aplicação, o Time Diary teve seus cinco campos (cinco perguntas que compõem o instrumento) traduzidos do inglês para o português por profissional habilitado (ANEXO VI).

Posteriormente, para a classificação e codificação das atividades diárias mencionadas, utilizou-se a Classificação de Atividades de Uso do Tempo (Time Use Activity Classification), conforme proposto pelo Australian Bureau of Statistics (1999; ANEXO VII).

Tanto o Time Diary como a Classificação de Atividades de Uso do Tempo são instrumentos elaborados e validados pelo Australian 
Bureau of Statistics (STINSON, 1999). Como mencionado na revisão, permitem comparabilidade internacional, necessitando apenas de tradução por pessoa habilitada, como realizado neste estudo. A classificação permite incluir, se necessário, atividades que não se enquadrem em nenhum de seus inúmeros códigos, como por exemplo, atividades específicas da cultura ou do universo do grupo estudado.

Considerando a natureza deste estudo, foram analisados apenas os nove grupos de atividades principais da classificação, uma vez que não interessava o detalhamento das atividades secundárias (por exemplo, detalhamento em minutos e porcentagem do dia), com sua complexa metodologia de análise.

O estudo de MOSS e LAWTON (1982), realizado com idosos, justifica esta prática, ao utilizar uma classificação de atividades semelhante á australiana, suprimindo, por questão de conveniência, atividades que não faziam parte do universo da pessoa idosa.

A duração da aplicação de todo o procedimento para cada idosa girou em torno de 45 a 60 minutos.

\subsubsection{Descrição do Clock Completion Test (ANEXO II)}

Proposto por WATSON, ARFKEN \& BIRGE (1993), avalia a "praxis construcional" a qual compreende percepção visoespacial, execução motora, atenção, compreensão da linguagem e conhecimento numérico. Segundo os autores, habilidades de percepção visoespacial encontram-se diminuídas nos estágios iniciais da doença de Alzheimer. O conceito de tempo e a capacidade para compreende-lo, manipulá-lo e representá-lo sob a forma de uma face de um relógio são altamente abstratas, requerendo, para tanto, muitos tipos de habilidades.

A administração deste teste consiste em desenhar num papel sem linhas um círculo com aproximadamente oito $\mathrm{cm}$ de diâmetro e pedir ao paciente que escreva números de 1 a 12 dentro do mesmo de modo que represente a face de um relógio 


\subsubsection{Modo de interpretação do Clock Completion Test}

Após a aplicação do teste. deve-se dividir o círculo em quatro quadrantes iguais tendo o número 12 ou a marca que melhor corresponda a esse número como referência. Quando executado corretamente, cada quadrante deve conter três números $(12$ a $2 ; 3$ a 5 ; 6 a 8 e 9 a 11 ). Se um número se situar sobre as linhas divisórias, ele será incluído no quadrante seguinte, em sentido horário. A presença de très números, sejam quais forem, em um quadrante é considerado correto. Iniciando com o digito que melhor corresponde ao número 12 e respeitando-se o sentido horário, os três primeiros quadrantes têm como resultado zero (normal) ou 1 (anormal). O quarto quadrante ( 9 a 11), que é o mais sensivel indicador de demência, recebe como resultado zero (normal) ou 4 (anormal). Somam-se os "scores" dos quadrantes. Um resultado de 4 a 7 é um bom indicador da presença de demència. Pacientes com demencia em geral tenderão a agrupar os números na metade direita do círculo. Embora este teste não indique a severidade da doença, os autores reportam uma sensibilidade de $87 \%$ e especificidade de $82 \%$ no diagnóstico de demência através da aplicação do mesmo.

\subsubsection{Registro de dados pessoais (ANEXO IV)}

$O$ instrumento conta com os seguintes campos:

- Dados de identificação: nome, idade, estado civil;

- Instrução: grau de instrução do individuo;

- Ocupação: ocupação atual, ocupação anterior;

- Residência: com quem reside, quantas pessoas residem na casa, tipo de propriedade (própria, alugada, residindo com filhos, outras);

- Situação econômica: se é independente economicamente, quantos salários mínimos recebe por mês.; 


\subsubsection{Time Diary (ANEXOS V e VI)}

A última etapa da entrevista consistiu na aplicação do Time Diary, proposto pelo Australian Bureau of Statistics (1992) para registro das atividades diárias. Em pesquisas destinadas a estudo do uso do tempo, este tipo de diário é deixado com o participante para que anote todas as atividades, registrando-as em intervalos de cinco minutos. A freqüencia (absoluta) de todas as atividades realizadas ou de atividades específicas é então multiplicada por esse valor, obtendo-se assim o tempo (em minutos) consumido na realização das mesmas. Portanto, na apresentação dos resultados, a frequência de realização de determinada atividade é identificada nas tabelas sob o termo valor absoluto.

A versão utilizada no estudo apresenta cinco colunas, traduzidas para o português, para efeito de aplicação, destinadas aos seguintes registros: atividade principal, para quem a atividade foi feita, que tipo de atividade era realizada conjuntamente (atividade secundária), onde (contexto físico) e com quem (contexto social) a pessoa se encontrava.

Como mencionado na revisão bibliográfica, idosos podem apresentar dificuldade motora ou visual, impedindo um registro adequado das atividades. Assim, realiza-se uma entrevista onde é feito um recordatório de todo o dia anteriormente vivenciado, dentro de um clima de informalidade. Esse instrumento tem a vantagem de praticamente eliminar o stress e situações de apreensão, as quais poderiam interferir na qualidade da informação obtida, principalmente ao se trabalhar com indivíduos idosos. Também permite a intervenção do entrevistador no sentido de auxiliar no recordatório, possibilitando incluir atividades que podem ser esquecidas pela pessoa. Isto porque, tem-se tendência a recordar apenas atividades que foram mais significativas durante o dia.

Devem ser descartadas as entrevistas incompletas, que evidenciem informações equivocadas, que reconstituam menos da 
metade do dia e aquelas cuja maior parte das informações são fornecidas por acompanhantes, caso estejam presentes.

Neste estudo, nenhuma entrevista foi descartada e toda informação foi dada pela própria entrevistada. Interessante observar que, além do relato das atividades realizadas, ocorreram vários relatos sobre história de vida, sentimentos e problemas familiares e pessoais.

\subsection{Análise e interpretação dos dados}

\subsubsection{Clock Completion Test}

Dado a rapidez na administração deste teste, o mesmo foi aplicado no mesmo dia da entrevista, antes do inicio da mesma.

Foi pedido que a idosa guardasse o relógio, caso o usasse, que se sentisse tranqüila, que levasse o tempo que julgasse necessário para escrever os números e que não olhasse para o relógio caso esse objeto fizesse parte do ambiente onde se realizava a entrevista. Também mencionou-se que não havia a necessidade de desenhar ponteiros e escalas de segundos na figura e que fossem evitadas rasuras nos desenhos.

Em geral, o teste foi concluído no máximo em um minuto, com algumas idosas levando menos de trinta segundos para realizá-lo. Para algumas, o teste tomou características de numa atividade lúdica.

Das 25 idosas que consentiram em participar da pesquisa, nenhuma foi excluída, conforme critérios estabelecidos pelo teste e descritos anteriormente. Os resultados demonstraram que as idosas estavam aptas cognitivamente a se lembrarem das atividades realizadas no dia anterior, conferindo assim ao conteúdo da entrevista um caráter maior de autenticidade e objetividade.

A título de ilustração, alguns resultados ("scores" normais) do teste encontram-se no ANEXO III, junto com escores anormais (obtidos em outra população), para efeito de comparação. 


\subsubsection{Time Diary}

Sob o formato de uma entrevista, foi solicitado à cada idosa que recordasse todos os eventos do dia anterior, a partir do momento que acordou até o momento em que foi deitar-se.

A entrevistadora anotou todas as informações e, após ter todas as atividades listadas na devida seqüencia e duração em que foram mencionadas, leu cada atividade em voz alta e perguntou que se mencionasse para quem a atividade foi feita, o que mais fazia ao mesmo tempo (atividade secundária), onde a atividade foi realizada (contexto físico) e quem estava presente durante a atividade (contexto social). Este procedimento permitiu a adição de atividades que poderiam ter sido esquecidas pelo fato de não serem consideradas relevantes.

Para atividades de caráter intimo ou particular, foi informado que, caso a pessoa não se sentisse à vontade para mencioná-las, que apenas se referisse como "privadas" ou "particulares".

Devido ao volume substancial das informações, o Time Diary foi feito recordando-se apenas um dia da semana por pessoa.

Neste estudo, foram recordadas atividades realizadas de segunda a sexta feira (portanto, as entrevistas realizaram-se somente de terça a sábado). Foram excluídos finais de semana porque, durante a semana, - leque de atividades é mais amplo, em virtude do funcionamento normal do comércio, bens e serviços já que finais de semana são mais devotados ao lazer.

Levantar e deitar-se foram considerados início e fim do recordatório diário e não são consideradas atividades para efeito de inserção nos grupos de atividades principais.

Todos os procedimentos acima foram realizados conforme MOSS e LAWTON (1982). 
5.5.3 Classificação das Atividades de Uso do Tempo (Time Use Activity Classification) (ANEXO VII)

A partir das informações do Time Diary, a classificação e codificação das atividades diárias mencionadas foi feita utilizando-se a classificação internacional proposta pelo Australian Bureau of Statistics (1999).

Todas as atividades mencionadas foram direcionadas para um dentre os nove grupos, codificados em um digito, conforme se segue:

1 - atividades de cuidados pessoais

2 - atividades relacionadas a trabalho

3 - atividades educacionais

4 - atividades domésticas

5 - atividades de cuidados (crianças)

6 - aquisição de bens e serviços

7 - trabalho voluntário e atividades de cuidado (adulto)

8 - interação social e comunitária

9 - recreação e lazer

Para efeito de validade da classificação, foi considerada a validade lógica, conforme proposto por GOODE \& HATT (1972), onde cada item da mesma é analisado e julgado conforme definição do "senso comum".

5.5.4 Atividades secundárias, contextos físico e social, tipo de trabalho e lazer

Neste estudo foram verificadas também as atividades secundárias, entendidas como atividades que são realizadas em paralelo às atividades principais.

Atividades secundárias foram categorizadas após o levantamento dos dados, conforme os resultados obtidos. Foram agrupadas em seis categorias e receberam os seguintes códigos:

1 - Nenhuma atividade

2 - Assistir televisão 
3 - Ouvir rádio

4 - Conversar

5 - Trabalho manual

6 - Trabalho doméstico

7 - Costurar

Com relação aos contextos físico e social, embora a classificação também apresente sua própria codificação para estas variáveis, neste trabalho os mesmos foram categorizados e codificados, de forma mais simples, após o levantamento dos dados, não seguindo portanto, a classificação australiana.

Todos os contextos físicos mencionados (locais de realização de atividades) foram distribuídos em sete categorias, recebendo os seguintes códigos:

1 - Na própria casa;

2 - Imóvel público (por exemplo, correio, hospital, prefeitura)

3 - Imóvel privado (por exemplo, consultórios médicos)

4 - Outro imóvel privado (por exemplo, imóvel de pessoa amiga)

5 - Transporte (por exemplo carro, metrô, onibus)

6 - Fora de casa (por exemplo praça, em frente á casa, na calçada)

7 - Outros (por exemplo caminhando)

Para efeito de análise, os espaços físicos foram dicotomizados em atividades ao ar livre $\mathrm{x}$ atividades dentro de casa. Esta variável foi usada como indicador de espaço físico.

O contexto social das atividades também foi avaliado, perguntado ao entrevistado: “A Sra. estava sozinha?". Se a mesma encontrava-se acompanhada, foi perguntado quem a acompanhava durante a atividade: esposa/esposo, filhos, parentes, acompanhantes, amigos, porteiros ou similares, outros. Os parceiros sociais foram distribuídos em seis categorias, recebendo os seguintes códigos:

1 - Sozinho

2 - Parentes

3 - Marido 
4 - Crianças

5 - Amigos

6- Profissionais

Para efeito de análise, o contexto social foi dicotomizado em sozinho x com outros.

Com relação às atividades remuneradas, como a classificação não apresenta o tipo de trabalho exercido, após levantamento dos dados, os tipos de, trabalho reportados pelas idosas foram decodificados conforme se segue:

1 - Serviços domésticos (empregada doméstica)

2 - Vendas (vendedora em loja ou de porta em porta)

3 - Trabalhos manuais (bordado, crochê, pintura em guardanapos)

4 - Culinária (fabricação de bolos e doces)

Com relação às atividades de lazer, a classificação apresenta sua própria categorização. Porém, neste trabalho, a partir dos resultados, optou-se por uma codificação mais simples, conforme se segue:

1 - Esportes

2 - Jogos/passatempos/hobbies

3 - Leitura

4 - Assistir televisão

5 - Dormir/cochilar

6 - Fazer visitas/ conversar/telefonar

7 - Viagem

8 - Participação em grupos de lazer/atividades.

Atividades não recordadas (lembradas) receberam o código "001", conforme mencionado na classificação.

\subsection{Tratamento estatístico}

Considerando apenas o dia efetivo de cada idosa (horas recordadas), foi utilizada a análise estatistica descritiva para verificar a distribuição dos nove grupos principais de atividades, em termos de 
valores absolutos, minutos e respectivas porcentagens. Os dados foram discutidos em termos de tendências observadas.

O mesmo procedimento foi adotado para o tipo de atividade remunerada, atividades de lazer e recreação, atividade secundária e contextos físico e social.

Os cálculos foram obtidos através da utilização do programa estatístico S-Plus ( S - PLUS, 1998). 


\section{RESULTADOS}

Os resultados serão apresentados para o grupo como um todo, tendo por base os nove grupos de atividades principais, conforme descrito no método. Será apresentada a distribuição das atividades cotidianas dentro destes grupos, considerando o dia efetivo do conjunto de idosas.

O dia efetivo (espaço compreendido entre o levantar-se e o deitar-se para dormir) consiste da média de duração do dia, expresso em minutos.

Dentre as 25 participantes, 18 estão dentro da faixa etária de 60 a 70 anos, 05 entre 71 e 80 anos, 01 entre 81 e 90 anos e 01 com mais de 91 anos. A idade média do grupo como um todo foi de 68,04 anos com desvio padrão de 8,36 anos. A Tabela 1 apresenta tais dados.

TABELA 1 - Distribuição da amostra segundo número, média e desvio padrão por faixa etária (anos).

\begin{tabular}{cccc}
\hline Faixa etária (anos) & $\mathrm{N}$ & Média & DP \\
\hline $\mathbf{6 0 - 7 0}$ & 18 & 63,9 & 3,2 \\
$\mathbf{7 1 - 8 0}$ & 5 & 73,8 & 2.1 \\
$\mathbf{8 1 - 9 0}$ & 1 & - & - \\
91 e mais & 1 & - & - \\
\hline TOTAL & 25 & 68,0 & 8,3 \\
\hline
\end{tabular}

Quanto ao estado civil, 11 eram casadas (44\%), 10 viúvas (40\%) e 03 desquitadas $(12 \%)$ e apenas 01 solteira (4\%).

Quanto à escolaridade, a maioria (16 idosas; 64\%) cursou até o terceiro ou quarto ano do antigo curso primário. A Tabela 2 descreve 
mais detalhadamente a amostra de conveniència com relação ao estado civil e escolaridade.

TABELA 2 - Distribuição do número e porcentagens de idosas segundo estado civil e escolaridade (em anos de estudo).

\begin{tabular}{ccc|ccc}
\hline Estado civil & $\mathbf{N}$ & $\%$ & Anos de estudo & $\mathbf{N}$ & $\%$ \\
\hline Solteira & 1 & 4 & $\mathbf{1 - 2}$ & 3 & 12 \\
Casada & 11 & 44 & $\mathbf{3 - 4}$ & 16 & 64 \\
Viúva & 10 & 40 & $\mathbf{5 - 6}$ & 2 & 8 \\
Desquitada & 3 & 12 & Acima de 6 & 4 & 16 \\
\hline TOTAL & 25 & 100 & TOTAL & 25 & 100 \\
\hline
\end{tabular}

Em termos de renda (TABELA 3), 09 idosas (36\%) referiram não receber nenhum tipo de benefício ou remuneração e 08 delas $(32 \%)$ a firmaram receber até um salário minimo.

TABELA 3 - Distribuição do número e porcentagens de idosas segundo renda ( em salários mínimos).

\begin{tabular}{ccc}
\hline $\begin{array}{c}\text { Renda } \\
\text { (em salário mínimo) }\end{array}$ & N \\
\hline Sem renda & 9 & 36 \\
$\mathbf{1}$ & 8 & 32 \\
$\mathbf{2}$ & 2 & 8 \\
$\mathbf{3}$ & 2 & 8 \\
Acima de 3 & 4 & 16 \\
\hline TOTAL & 25 & 100 \\
\hline
\end{tabular}


Também a grande maioria referiu ter exercido apenas a atividade de dona de casa (19 idosas; 76\%) antes dos 60 anos sendo que aquelas que exerciam tal atividade somada ao exercicio de uma profissão remunerada foram de apenas 06 idosas (24\%).

Após os 60 anos, $68 \%$ delas (17 mulheres) dedicavam-se apenas às atividades domésticas enquanto aquelas que, além dos cuidados com a casa exerciam atividade remunerada, somam 08 idosas $(32 \%)$.

Os tipos de atividades exercidos eram os de empregada doméstica (em geral cuidando da casa de um membro da família), vendas, confeç̧ão de artesanato e culinária.

A Tabela 4 descreve a amostra com relação à ocupação antes e após 60 anos.

TABELA 4 - Distribuição do número e porcentagens de idosas segundo ocupação doméstica (do lar) e trabalho (remunerado) antes e após os 60 anos.

\begin{tabular}{ccc|ccc}
\hline $\begin{array}{c}\text { Ocupação } \\
\text { (antes 60 anos) }\end{array}$ & $\mathbf{N}$ & $\%$ & $\begin{array}{c}\text { Ocupação } \\
\text { (após 60 anos) }\end{array}$ & $\mathbf{N}$ & $\%$ \\
\hline do lar & 19 & 76 & do lar & 17 & 68 \\
trabalho & 6 & 24 & trabalho & 8 & 32 \\
\hline TOTAL & 25 & 100 & TOTAL & 25 & 100 \\
\hline
\end{tabular}

Quanto ao aspecto de moradia, todas referiram residir em imóvel próprio, morando ou sozinhas (06 mulheres; $24 \%$ ) ou com até uma pessoa, em geral marido ou filho (12 idosas; 48\%). A Tabela 5 descreve a amostra com relação ao número de pessoas residentes no domicílio. 
TABELA 5 - Distribuição do número e porcentagens de pessoas residentes no domicílio.

\begin{tabular}{ccc}
\hline $\begin{array}{c}\text { Número de residentes no } \\
\text { domicílio }\end{array}$ & $\mathrm{N}$ & $\%$ \\
\hline Mora só & 6 & 24 \\
$\mathbf{1}$ & 12 & 48 \\
Mais de 2 & 3 & 12 \\
\hline TOTAL & 4 & 12 \\
\hline
\end{tabular}

Considerando-se o dia efetivo, o tempo foi distribuido entre os nove grupos de atividades principais, conforme Tabela 6 e Figura 1.

TABELA 6 - Distribuição dos grupos principais de atividades (valores absolutos, minutos e percentuais) em relação ao dia efetivo.

\begin{tabular}{lccc}
\hline Grupos principais de atividades & Valor absoluto & Minutos & $\%$ \\
\hline Cuidados pessoais & 791 & 3955 & 16,2 \\
Emprego/ocupação & 672 & 3360 & 14 \\
Atividades educacionais & - & - & - \\
Atividades domésticas & 1610 & 8050 & 33 \\
Cuidados com crianças & 13 & 65 & 0,2 \\
Aquisição de bens e serviços & 82 & 410 & 1,7 \\
Trabalho voluntário/cuidados & 31 & 155 & 0,6 \\
Atividades sociais & 310 & 1550 & 6,3 \\
Recreação e lazer & 1256 & 6280 & 26 \\
Atividades não recordadas & 97 & 485 & 2 \\
\hline \multicolumn{1}{c}{ TOTAL } & 4.862 & 24.310 & 100 \\
\hline
\end{tabular}


O valor absoluto corresponde ao número de ocorrências de comportamentos que são classificados como pertencentes à um dos grupos específicos de atividades. De acordo com o método adotado, todo comportamento (ou ação) é registrado como ocorrendo a intervalos de cinco minutos. Assim, o valor absoluto multiplicado por essa unidade de tempo, indica o total (em minutos) de tempo despendido pelo grupo de idosas em cada grupo de atividades principais.

Para o grupo, o dia efetivo somou 24.310 minutos. Em média, para cada idosa, o dia efetivo foi de 972,4 minutos (16h20 min). Maior e menor valor para o dia efetivo foram 1.110 e 855 minutos respectivamente. Contudo, faz-se necessário salientar que determinada atividade não foi executada pelo grupo como um todo, ficando restrita a algumas idosas. Isto se verificou com relação à atividade remunerada onde, das 25 idosas, apenas 08 dedicavam parte do dia à esta tarefa.

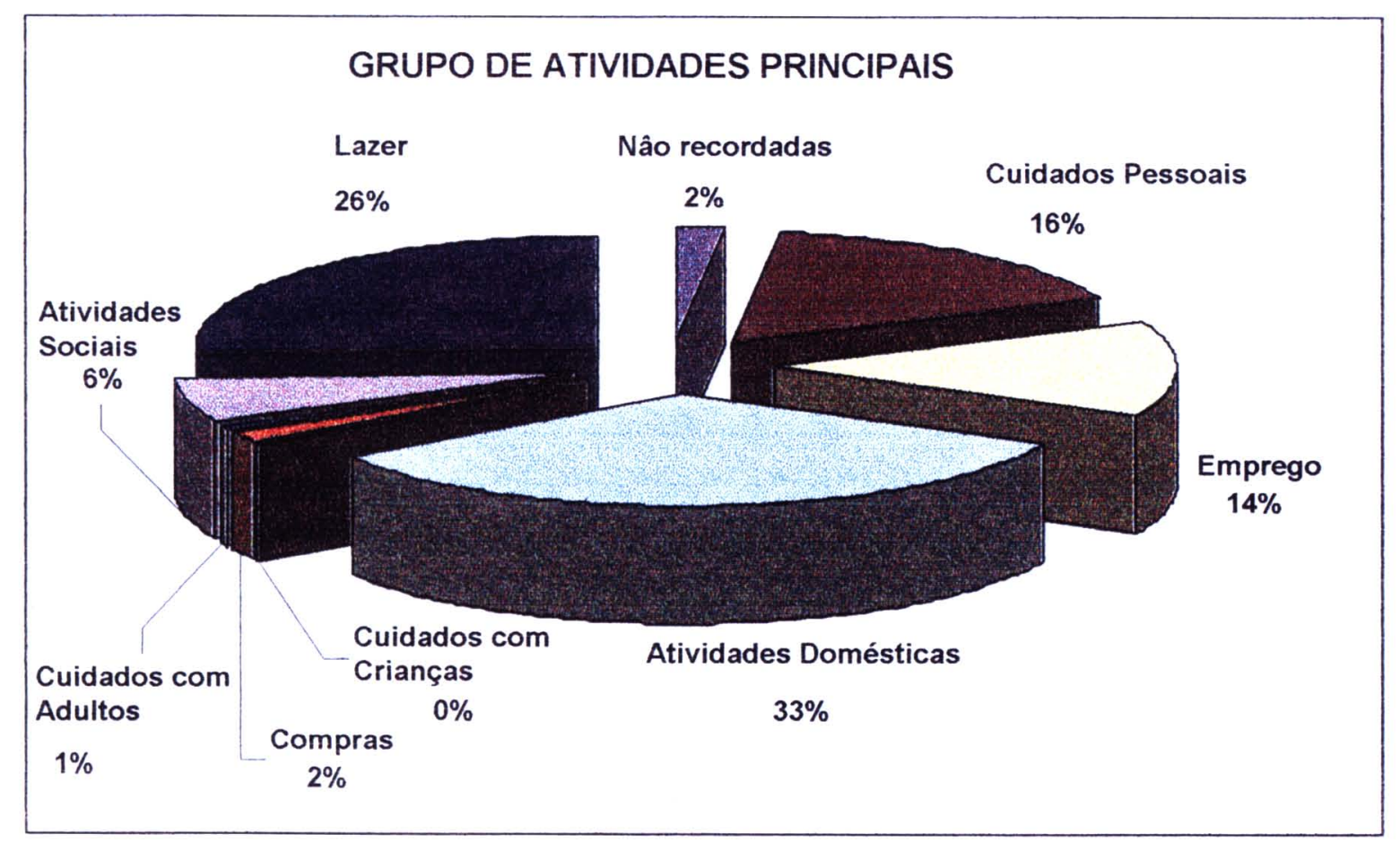

Figura 1 - Distribuição percentual dos grupos de atividades principais em relação ao dia efetivo. 
No ANEXO VIII podem ser vistos fluxogramas de atividades para cada grupo de atividades principais (exceção são as atividades educacionais pois não foram mencionadas em nenhuma ocasião). Os mesmos retratam o fluxo das atividades do grupo ao longo do dia bem como evidenciam seus picos e comportamentos característicos. No eixo horizontal, tem-se o tempo, representado em 250 intervalos de 5 minutos e, no vertical, tem-se o número de pessoas que estavam executando aquela atividade em intervalos especificos. " 0 " indica o acordar (a idosa que mais cedo levantou-se acordou ás 04 h00) e "250" indica o momento em que a maioria já havia se deitado para dormir (a idosa que mais tarde deitou-se disse tê-lo feito às $02 \mathrm{~h} 30 \mathrm{~min}$ ).

Como pode ser visto, em geral atividades de cuidados pessoais ocupam todo o dia, tendendo à uma uniformização ao longo do mesmo. O mesmo pode ser verificado com as atividades sociais. Já as atividades domésticas tem maior freqüencia de ocorrência pelas manhãs e atividades de lazer concentram-se no periodo da tarde.

O trabalho remunerado ocupou $14 \%$ do dia efetivo $(3.360$ minutos). Esta proporção de tempo foi distribuída em atividades como prestação de serviços domésticos, vendas, confecção de bordado/artesanato e bolos e doces (culinária).

Dentre estas, predominou atividades de vendas (32\%), seguida de confeç̧ão de trabalhos manuais e prestação de serviços domésticos, ambas com $28 \%$ e trabalho culinário com $12 \%$. A Tabela 7 apresenta os resultados. 
TABELA 7 - Distribuição dos tipos de atividades remuneradas (valores absolutos, minutos e percentuais).

\begin{tabular}{|c|c|c|c|}
\hline Tipos de atividades remuneradas & Valor absoluto & Minutos & $\%$ \\
\hline Serviço doméstico & 186 & 930 & 28 \\
\hline Vendas & 217 & 1085 & 32 \\
\hline Trabalhos manuais & 188 & 940 & 28 \\
\hline Culinária & 81 & 405 & 12 \\
\hline TOTAL & 672 & 3.360 & 100 \\
\hline
\end{tabular}

A Figura 2 ilustra como o trabalho se distribuiu entre as quatro diferentes atividades mencionadas.

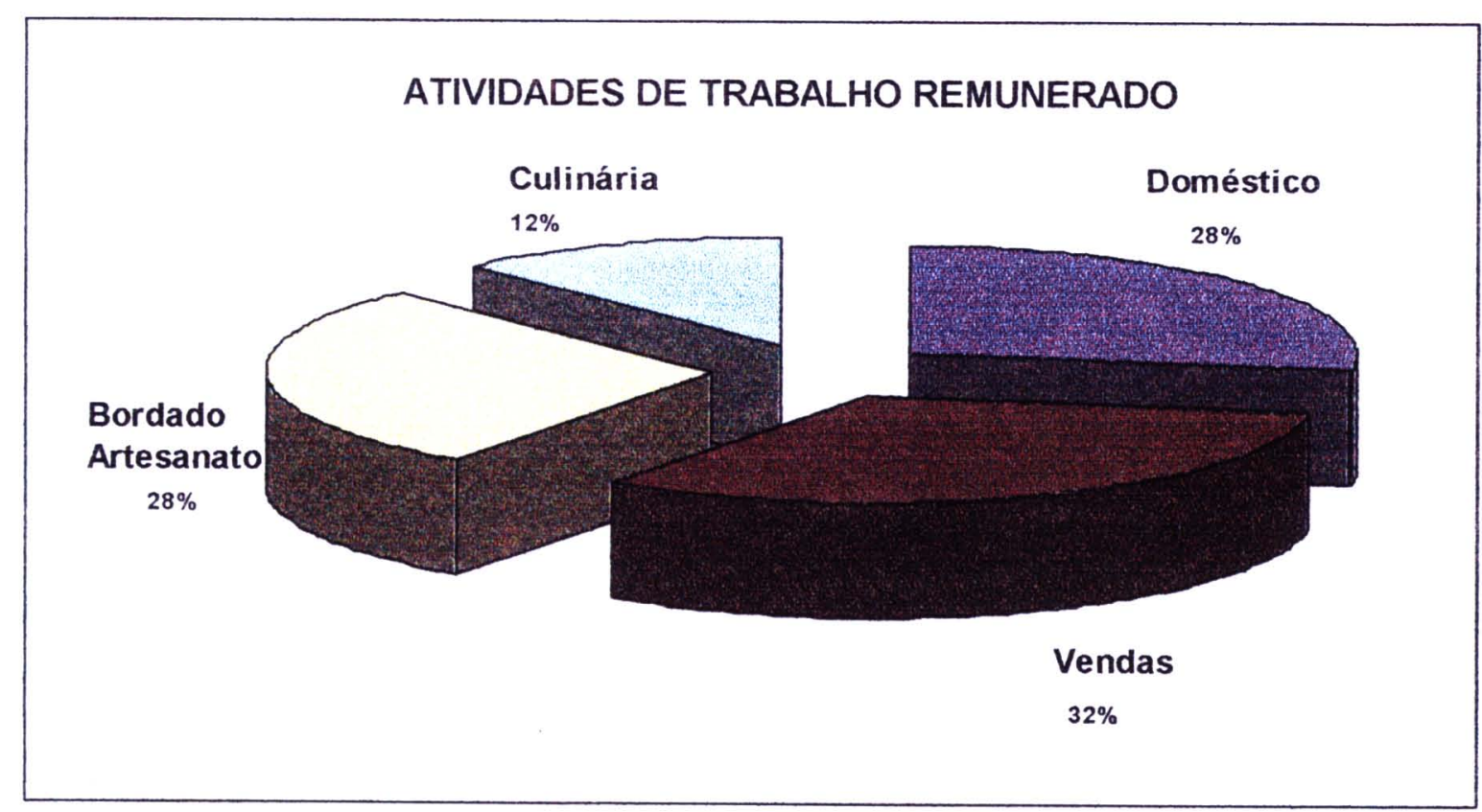
Figura 2 - Distribuição percentual das atividades de trabalho remunerado.

Em termos de lazer e recreação, o grupo principal de atividades deste grupo ocupou $26 \%$ do dia efetivo. Essa proporção foi distribuída 
entre várias atividades secundárias: esportes, jogos/hobbies, leitura, assistir televisão, cochilar, fazer visitas, viagens e participação em grupo de convivência. A Tabela 8 e a Figura 3 apresentam os resultados

Como pode ser visto, praticamente metade do tempo destinado às atividades de lazer e recreação $(47 \%)$ foi utilizado para assistir televisão. Fazer visitas foi a segunda atividade mais freqüente dentro deste grupo principal (16\%) seguida de viagens (10\%). Jogos/hobbies, cochilar, esportes, leitura e participar de grupos de convivência obtiveram $8,6,5,4$ e $4 \%$ respectivamente.

TABELA 8 - Distribuição das atividades de lazer e recreação (valores absolutos, minutos e percentuais).

\begin{tabular}{|c|c|c|c|}
\hline Atividades de Lazer e Recreação & Valor absoluto & Minutos & $\%$ \\
\hline Esportes & 62 & 310 & 5 \\
\hline Jogos/Hobbies & 106 & 530 & 8 \\
\hline Leitura & 49 & 245 & 4 \\
\hline Assistir televisão & 586 & 2930 & 47 \\
\hline Cochilar & 81 & 405 & 6 \\
\hline Fazer visitas & 204 & 1020 & 16 \\
\hline Viagens & 120 & 600 & 10 \\
\hline Grupos de convivência & 48 & 240 & 4 \\
\hline TOTAL & 1.256 & 6.280 & 100 \\
\hline
\end{tabular}




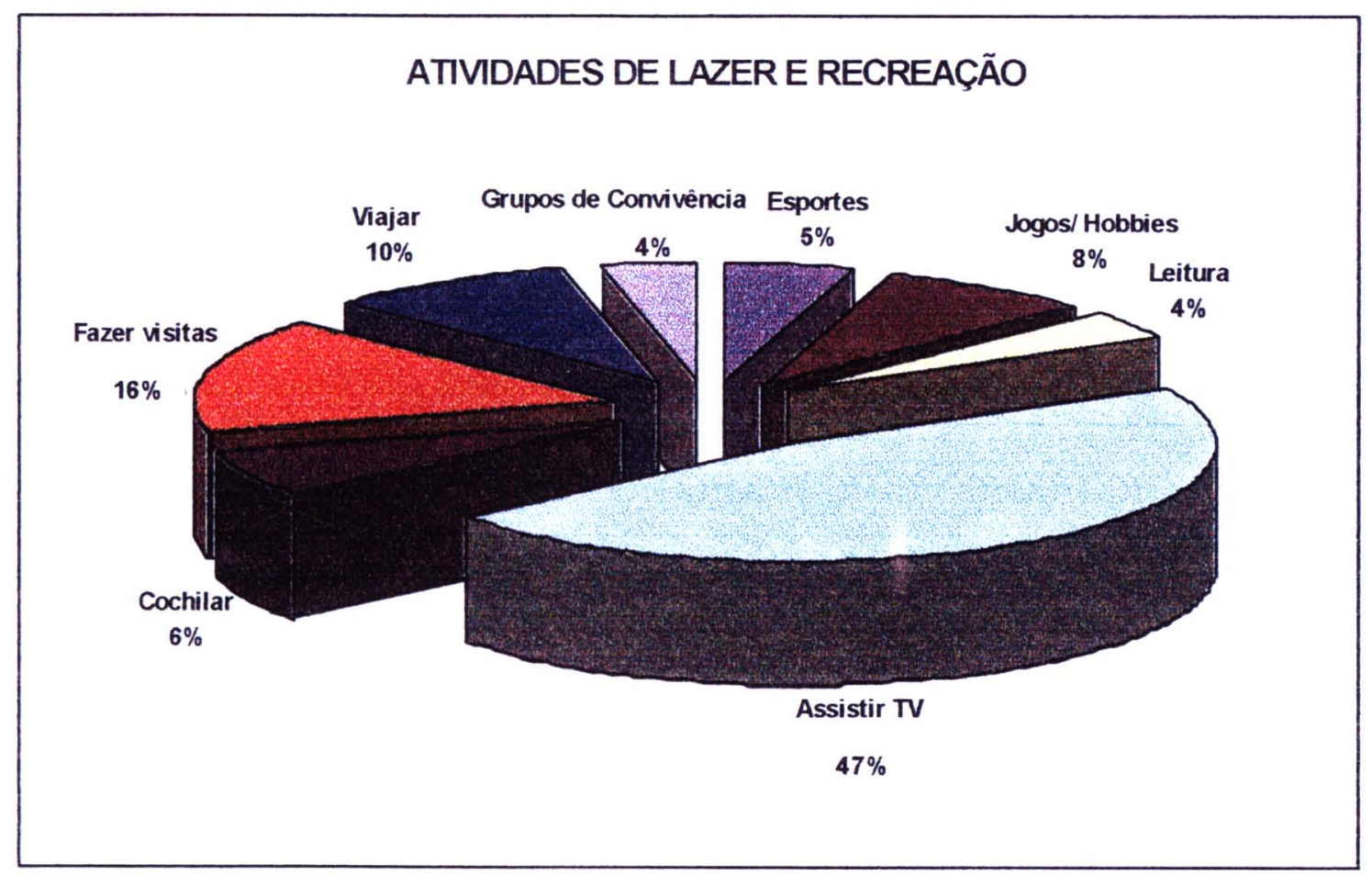

Figura 3 - Distribuição percentual das atividades de lazer e recreação.

Com relação às atividades que podem ser realizadas em paralelo às atividades principais, também denominadas atividades secundárias, estas foram referidas conforme Tabela 9 e Figura 4.

A maioria das idosas mencionou não executar nenhuma atividade simultânea $(43 \%)$, seguida por conversas $(37 \%)$ e ouvir rádio $(14 \%)$. Outras atividades como assistir televisão, trabalho manual e doméstico e costura não apresentaram relevância em relação às duas primeiras atividades. 
TABELA 9 - Distribuição das atividades secundárias (valores absolutos, minutos e percentuais).

\begin{tabular}{lccc}
\hline \multicolumn{1}{c}{ Atividades Secundárias } & Valor absoluto & Minutos & $\%$ \\
\hline Nenhuma atividade & 2136 & 10680 & 43 \\
Assistir televisão & 123 & 615 & 3 \\
Ouvir rádio & 659 & 3295 & 14 \\
Conversar & 1784 & 8920 & 37 \\
Trabalho manual & 45 & 225 & 1 \\
Trabalho doméstico & 7 & 35 & 0 \\
Costurar & 11 & 55 & 0 \\
Não recordadas & 97 & 485 & 2 \\
\hline \multicolumn{1}{c}{ TOTAL } & 4.862 & 24.310 & 100 \\
\hline
\end{tabular}

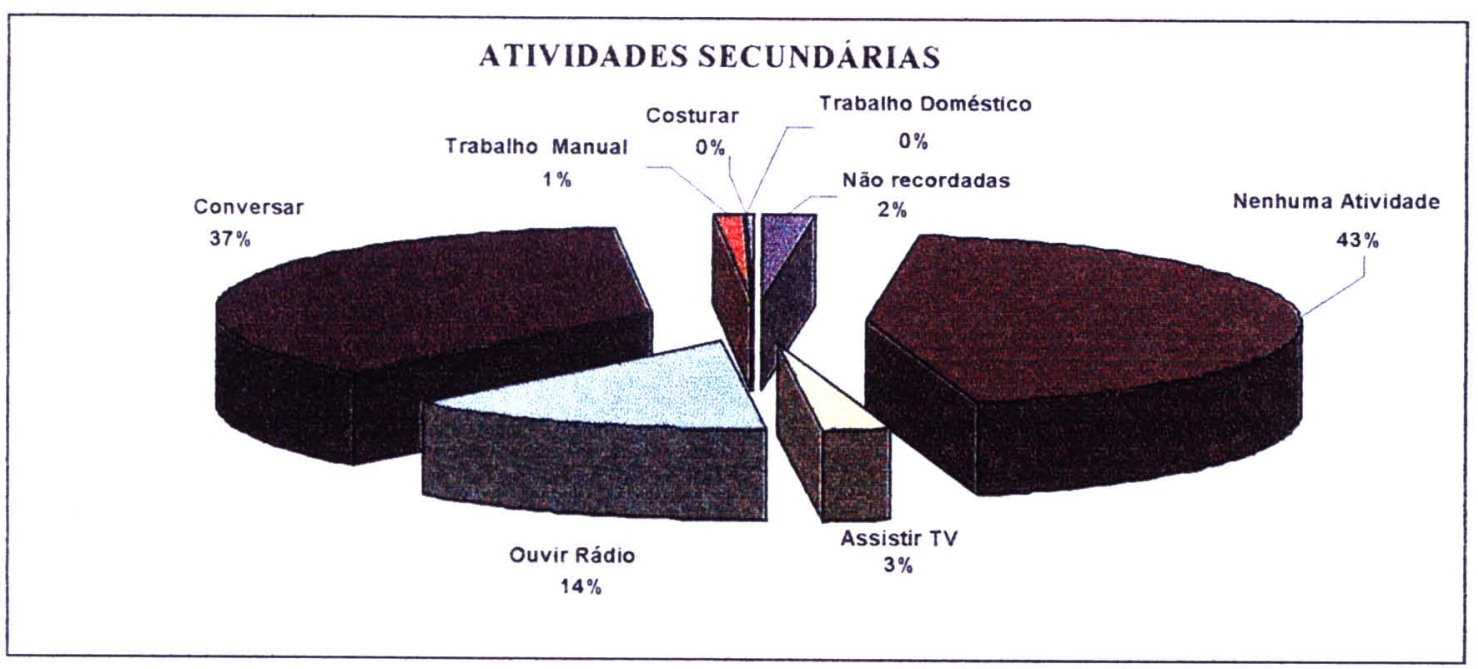

Figura 4 - Distribuição percentual das atividades secundárias.

O contexto físico (aonde), um indicativo do espaço geográfico das idosas, mostra claramente, conforme Tabela 10 e Figura 5, que o 
principal ambiente de realização das atividades diárias ocorre no próprio domicilio (74\%), seguido de outros imóveis privados, representados exclusivamente pelas residencias de amigas ou amigos (13\%). Em relação às duas primeiras categorias, as demais não apresentam relevància em termos de suas respectivas porcentagens.

TABELA 10 - Contextos físicos das atividades principais (valores absolutos, minutos e percentuais).

\begin{tabular}{lccc}
\hline \multicolumn{1}{c}{ Contexto Físico } & Valor absoluto & Minutos & $\%$ \\
\hline Própria casa & 3620 & 18100 & 74 \\
Edifício público & 129 & 645 & 3 \\
Edifício privado & 3 & 15 & 0 \\
Outro imóvel privado & 668 & 3340 & 13 \\
Transporte & 185 & 925 & 4 \\
Fora de casa & 126 & 630 & 3 \\
Outros & 34 & 170 & 1 \\
Não recordado & 97 & 485 & 2 \\
\hline \multicolumn{1}{c}{ TOTAL } & 4.862 & 24.310 & 100 \\
\hline
\end{tabular}




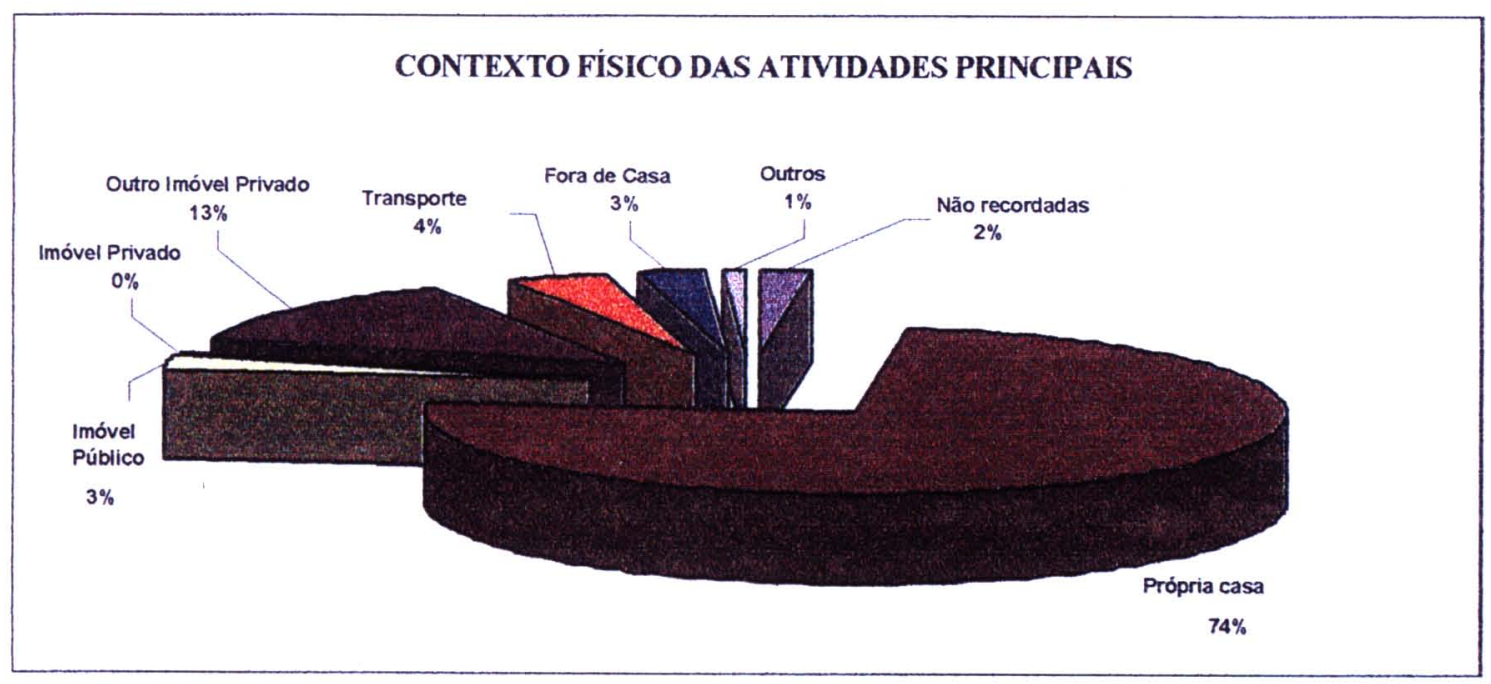

Figura 5 - Distribuicão percentual do contexto físico dos grupos de atividades principais.

O contexto físico pode ser dicotomizado em atividades realizadas dentro de casa e atividades realizadas fora de casa. Assim, $74 \%$ de todo comportamento diário foi realizado no ambiente doméstico enquanto somente $24 \%$ ocorreu fora dele (já excluindo $2 \%$ de atividades não recordadas).

Já o contexto social (com quem), um indicativo do espaço relacional das idosas, pode ser verificado na Tabela 11 e Figura 6.

Evidencia-se que a maior parte do dia efetivo das idosas se passou na companhia de parentes (47\%), seguido de atividades executadas estando sozinhas $(28 \%)$ e, em terceiro, na presença do marido $(15 \%)$. 
TABELA 11 - Contextos sociais das atividades principais (valores absolutos, minutos e percentuais)

\begin{tabular}{|c|c|c|c|}
\hline Contexto Social & Valor absoluto & Minutos & $\%$ \\
\hline Sozinho & 1363 & 6815 & 28 \\
\hline Parentes & 2295 & 11475 & 47 \\
\hline Marido & 735 & 3675 & 15 \\
\hline Crianças & 322 & 1610 & 7 \\
\hline Amigos & 10 & 50 & 0 \\
\hline Profissionais & 40 & 200 & 1 \\
\hline Não recordado & 97 & 485 & 2 \\
\hline TOTAL & 4862 & 24.310 & 100 \\
\hline
\end{tabular}

De igual modo. o contexto social também pode ser analisado em termos de atividades realizadas sozinha, com familia (incluindo marido e parentes) e atividades realizadas na companhia de terceiros.

Assim, $28 \%$ das atividades foram realizadas estando a idosa sozinha, $62 \%$ na presença de um ou mais membros da familia e somente $8 \%$ na presença de terceiros (também excluindo $2 \%$ de atividades não recordadas) 


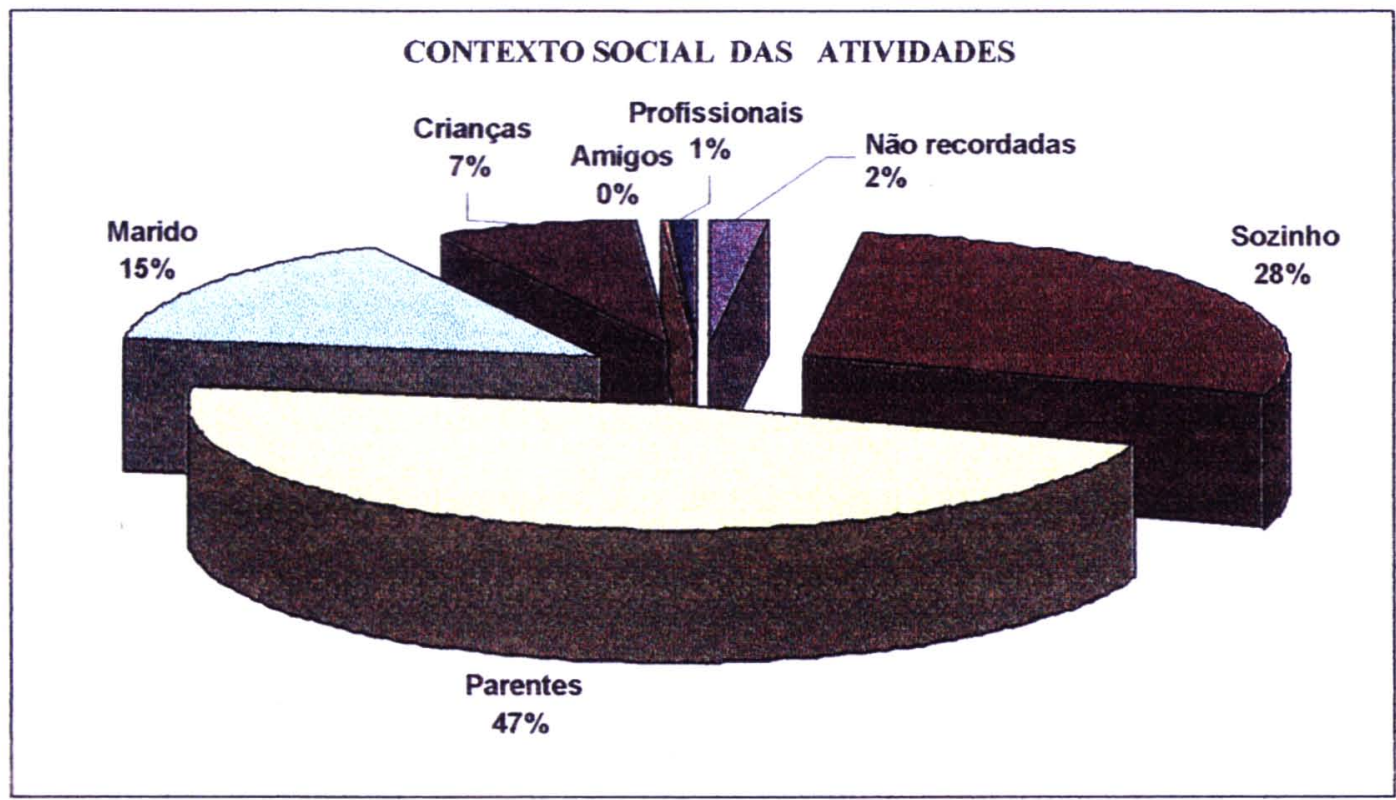

Figura 6 - Distribuição percentual do contexto social dos grupos de atividades principais.

Portanto, ao se dicotomizar o contexto social entre estar só e estar na presença de outras pessoas, verifica-se que, embora o espaço físico preponderante seja o ambiente doméstico, a maior parte do dia efetivo das idosas é vivenciado na presença de vários parceiros sociais 


\section{DISCUSSÃO}

Inicialmente ressalta-se que a discussão e observações sobre os resultados deste trabalho são válidos somente para o grupo estudado.

Uma primeira análise mostrou que o cotidiano das idosas constituiu-se de atividades normais e rotineiras, de forma idêntica à vida de toda pessoa.

Assim, em princípio, a vida cotidiana pareceu desenvolver-se dentro da mais absoluta trivialidade, onde as mulheres puderam ser vistas como figuras passivas, cujos estados interiores dependiam das condições externas, do que faziam, onde e com quem estavam.

Embora isso seja em parte verdadeiro, não são as condições externas que importam ou seja, a excelência da vida cotidiana depende, em última instância, não do contexto externo mas do modo como a energia psíquica é empregada em tudo que é realizado.

Porém, a diversidade é uma característica fundamental e presente, sobretudo no envelhecimento, dado a multidimensionalidade e variabilidade desse processo.

Partindo do significado do que seja viver, verifica-se que a vida, do ponto de vista biológico, é um processo automático, desde que satisfeitas as necessidades fisiológicas do organismo.

Viver extrapola a esfera da espontaneidade na medida em que, se a pessoa não assume a direção de sua própria vida, tem-se como praticamente certo que esta será controlada pelo mundo exterior para servir a propósitos alheios à ela, independente do modo como isto o afeta. Assim, não se pode esperar que um viva a vida pelo outro mas que descubra como fazer isso por conta própria, caso se deseje uma vida autônoma e independente. Isto implica entender a vida num sentido mais amplo, pleno, expressando a própria individualidade e participando intimamente da complexidade do universo a redor da pessoa.

A vida humana é, em parte, determinada por processos químicos do organismo, pela interação biológica entre órgãos e sistemas, pelas 
interações sinápticas e pela organização da informação que a cultura impõe sobre a mente do homem. Mas, a qualidade real da vida, o que se faz e o que se sente frente a isso, é determinado pelos pensamentos e emoções, pelas interpretações que são dadas a processos químicos, biológicos e sociais, onde toda emoção que impele o homem à agir compartilha de uma dualidade básica que é ser atraente ou repulsiva.

Concordando ou não, todos estão sujeitos aos limites daquilo que se pode fazer e sentir e não reconhecê-los pode levar à uma sensação de fracasso. Desta forma, compreender a realidade do cotidiano, com todas as suas exigências e frustrações, pode contribuir para o alcance de uma melhor qualidade de vida e um melhor gerenciamento da mesma.

Uma visão puramente biológica da vida remete toda pessoa à repetição de padrões comportamentais na medida em que a estrutura do seu sistema nervoso opera de modo a processar pouca quantidade de informação de cada vez. A grande maioria daquilo que ela experimenta precisa ocorrer num fluxo seqüencial, uma coisa após outra. Por vez, lê-se uma só revista, ouve-se uma só música, participase de uma só conversa, engole-se um só bocado. Assim, pode-se inferir que, em diferentes épocas e culturas, o que as pessoas fazem e por quanto tempo o fazem tem o crivo da similaridade.

Se em alguns aspectos todas as vidas se apresentam de forma similar e com alguns parâmetros fixados ou seja, ninguém pode evitar o repouso, alimentação, interação e algum tipo de trabalho, por outro lado tais vidas podem ser divididas quanto ao gênero, categoria social e idade.

Estes três aspectos determinam, em grande parte, o modo como pessoas vivem e o conteúdo específico dos seus cotidianos. O quadro completa-se e ao mesmo tempo assume tal complexidade quando somase á ele a questão da individualidade, a qual atribui ao homem uma mente própria, uma flexibilidade de consciência, tornando-o capaz de 
tomar decisões próprias, de aproveitar ou desperdiçar oportunidades e de vencer ou sucumbir às desvantagens da vida.

Viver significa experimentar sempre, por meio de atos, sentimentos, pensamentos, dentro de um contexto e de limites, sendo que toda essa experiência ocorre no tempo. Isto é o que faz dele o recurso mais escasso que o homem possui.

A medida da consciência de que tempo é o único recurso não reciclável que a pessoa recebe pode interferir no padrão de suas atividades porque a forma como se usa o tempo pode ser proporcional ao valor que se atribui à vida.

Tudo aquilo que se constitui em conteúdo da vivência diária, com o passar do tempo (dos anos) determinará a qualidade de vida da pessoa. Assim, o modo como o tempo é alocado é, sem dúvida, uma decisão essencial na vida e entender toda essa estruturação, através do grande número de respostas que um estudo de uso do tempo fornece, é importante na medida em que permite observar a forma e qualidade da vida cotidiana em grandes detalhes e com considerável precisão.

O desempenho nas atividades diárias, além de sofrer interferências da personalidade individual, pode estar associado à idade, gênero, incapacidades, presença de doenças crônicas, nível sócioeconômico, estado civil, condições de moradia e infra-estrutura (VAAN DEN HOMBERGH et al., 1995). Todos estes aspectos em conjunto contribuem para dar á vida cotidiana seu tom de diversidade e podem ter influenciado, em graus variados, a escolha e execução das atividades e, por conseguinte, o nível de competência das idosas estudadas. Embora não tenha sido objetivo avaliar a influência de aspectos individuais em relação ás atividades diárias, estes certamente contribuíram para a configuração do quadro obtido.

Em relação à idade, faz-se importante salientar que ela não é um fator de homogeneização de condições entre pessoas idosas. Ao contrário, à medida que avançam em anos, tornam-se menos parecidas e muito mais sujeitas à todas as conseqüencias do acúmulo de uma 
série de fatores por ocasião do processo de envelhecimento: a genética, o gênero, raça, condição econômica, escolaridade, estado civil, alimentação e cuidados prévios com a saúde fundem-se e tornam-se os determinantes de sua saúde e longevidade.

Ainda tendo por base o critério cronológico adotado neste estudo, poderia se dizer que a maioria das idosas se depararam, aos sessenta anos, com todas as desvantagens acumuladas pela discriminação, desigualdades e falta de oportunidades ao longo da vida, onde a maioria não teve trabalho remunerado e escolaridade adequada e conta, hoje, somente com os benefícios de uma aposentadoria minima.

Segundo BERQÜO (1996), é muito baixa a escolaridade da população idosa e é maior a porcentagem de mulheres analfabetas em relação aos homens. Ainda segundo a autora, entre idosos que conseguiram chegar à escola, apenas $50 \%$ conseguiram completar o curso primário. Sobre este assunto, tais colocações se encaixam para a maioria das idosas estudadas. A questão da baixa escolaridade da mulher idosa tem reflexo direto na sua busca por melhores condições de existência e de sobrevivência.

Em termos econômicos, verificou-se que parte das idosas dependia financeiramente do marido (ou filhos) porque, envolvidas por um modelo de comportamento tradicional, sua ação foi restrita a governar a família e a educar os fillhos, não cabendo espaço para a realização profissional e, consequentemente, econômica.

Entre idosos vinculados ao mercado de trabalho, o ganho não ultrapassava dois salários minimos, o que faz do baixo rendimento uma das características da pessoa idosa (CHAIMOWICZ, 1998), principalmente para as mulheres, devido às suas desvantagens acumuladas ao longo da vida. Estas observações também parecem verdadeiras para a maioria das mulheres estudadas.

Em relação ao estado civil, não é o estar só (viúva, solteira, desquitada) que coloca a vida das idosas em risco mas sim as mesmas 
considerações mencionadas acima ou seja, o acúmulo de uma série de desigualdades pode se refletir na qualidade de vida das mulheres, levando-as a um maior número de situações de fragilidade e limitação social.

Na revisão deste trabalho, foi também mencionado que o estudo do uso do tempo é uma medida do espaço psicológico e social. Por esse motivo, MOSS e LAWTON (1982) propuseram avaliar a alocação do tempo como indicador de comportamento ou seja, indicador de estilo de vida onde o comportamento competente da pessoa idosa para lidar com todos os aspectos da sua vida é um dos determinantes de tal estilo.

Deve-se salientar que o modo de alocação do tempo não depende unicamente da pessoa porque, como membro de uma sociedade ou cultura, existem limites que se interpõem entre querer e poder fazer. Contudo, há espaço para escolhas, opções pessoais onde o tempo está, de certo modo, sob total controle da pessoa. É dentro desse contexto que diferentes estilos de vida emergem e revelam muito do cotidiano das pessoas idosas.

Em relação à execução de atividades, a análise dos grupos principais de atividades claramente evidenciou que estas se distribuiram, em maior proporção, em atividades obrigatórias conjunto de atividades básicas (KATZ et al., 1963) e instrumentais (LAWTON \& BRODY, 1969) ou seja, a maior parte do dia efetivo das idosas foi gasto na execução de comportamentos necessários à uma adequada manutenção do viver, tanto do ponto de vista fisiológico quanto do aspecto organizacional do ambiente.

A estas atividades obrigatórias somou-se o trabalho, uma atividade de caráter produtivo, cuja finalidade última visa um viver com mais conforto, podendo criar oportunidades de novas experiências (CSIKSZENTMIHALYI, 1999).

Assim, os resultados sugerem semelhanças aos reportados por BALTES e colaboradores (1990) em relação ao grupo de atividades 
domésticas e de cuidados pessoais, os quais caracterizam-se pela realização freqüente de atividades consideradas obrigatórias.

Através do fluxograma de atividades, verificou-se que o tempo gasto na realização de atividades domésticas ocupou predominantemente as manhãs enquanto que cuidados pessoais distribuiu-se de modo mais ou menos uniforme ao longo do dia. Já as atividades de lazer concentram-se no periodo da tarde evidenciando que as opções pelas atividades discrecionárias ocorrem após o cumprimento de atividades ditas essenciais.

Os resultados também sugerem semelhanças com as observações de VERBRUGGE e colaboradores (1996), porque se evidenciou no grupo maior tendência de realização de atividades obrigatórias e lazer passivo (assistir televisão) e também um aumento do tempo consumido no trabalho remunerado.

Neste estudo, o fato de serem as atividades domésticas o grupo de maior freqüencia de atividades pode ser indicativo da herança cultural onde à mulher cabia o papel de encarregada do trabalho de manutenção enquanto ao homem recaia o papel produtivo, impondo assim uma rotulação sexual para as tarefas domésticas.

Apesar das facilidades advindas da tecnologia, as idosas parecem dedicar uma grande parte do dia para impedir o colapso da infra-estrutura organizacional de suas famílias. Esse modelo de conduta social que vem se mantendo com o tempo, pode estar ameaçado pelas mudanças estruturais que se observam no mundo do trabalho, pelas transformações ocorridas na família e relações de gênero onde o papel de "dona de casa" e o de "mantenedor do lar" se modificou.

Os resultados mostraram grande parte do tempo alocado em atividades de lazer ou recreação, um grupo que engloba a grande maioria das atividades chamadas discrecionárias (MOSS \& LAWTON, 1982), que são escolhidas pela própria pessoa e caracterizadas por envolver afeto, conhecimento, prazer e interesse e também por 
sofrerem influência de inúmeros fatores como idade, cognição e nível sócio econômico.

O encaminhamento dos filhos e a viuvez podem ser fatores responsáveis por maior quantidade de tempo livre já que há diminuição de responsabilidades e preocupações domésticas com a diminuição da família.

É durante o lazer que a pessoa pode dedicar tempo ao seu desenvolvimento pessoal, em inúmeras atividades de aprendizado e artes e na prática de atividade física, por exemplo. Contudo, tal ideal quase nunca se realiza pois é comum em nossa sociedade que o tempo livre seja ocupado em sua maior parte pelo consumo maciço de mídia, principalmente assistir televisão, com pouco tempo sendo dedicado às atividades mais exigentes em termos cognitivos ou seja, o tempo livre é em grande parte consumido sob forma de lazer passivo, o que foi constatado neste estudo.

Embora assistir televisão possa trazer algum tipo de informação interessante, em geral os programas vão mais de encontro ao deleite do que ao enriquecimento do espectador ou seja, aquilo que a maioria das pessoas assiste, dificilmente ajudará no desenvolvimento pessoal.

Um uso mais ativo para o lazer, empregado em hobbies, cinema e esportes foi pouco verificado.

$O$ pouco envolvimento em algum tipo de atividade física tornase preocupante na medida em que o exercicio regular vem sendo apontado como tendo importante papel na preservação da qualidade de vida, na redução de agravos e da mortalidade e na manutenção da independência da pessoa idosa.

O lazer passivo torna-se um problema quando é usado como principal ou único meio para ocupar o tempo disponivel. Na medida em que tais padrões tornam-se hábitos, surtem efeitos definidos na qualidade de vida como um todo.

A gênese para ocupação do tempo livre com lazer passivo pode também passar pela questão da solidão pois, pessoas solitárias e 
insatisfeitas com vários aspectos de suas vidas, podem vir a preencher seu tempo livre com este tipo de atividade ou seja, não encontrar satisfação e motivação em alguns aspectos da vida pode direcionar as experiências cotidianas para atividades pouco exigentes e dinâmicas.

Outro aspecto a ser considerado relaciona-se ás atividades produtivas que, ao passarem a ser rotineiras e carentes de um significado mais profundo, podem ser substituidas por atividades de lazer, as quais preenchem os periodos de inatividade apoiando-se cada vez mais em estímulos artificiais de complexidade crescente.

A era da tecnologia oferece uma grande variedade de entretenimento que vem se sofisticando ao longo dos anos, os quais excitam os sentidos mas impedem apreciar as realidades que circundam a vida e que podem ser fontes de continuo crescimento individual. Por conta disso, o lazer ativo que poderia colaborar para essa finalidade não encontra facilidade para se consubstanciar.

O lazer era visto como um período no qual pessoas tinham oportunidades de experimentar e desenvolver novas habilidades, encontrando nele uma oportunidade de explorar a beleza e o conhecimento e, o mais importante, acrescentando satisfação e interesse às suas próprias vidas. Na atualidade, a midia tira, em parte, a capacidade da pessoa de realizar atividades interessantes que possam estar vinculadas ao aumento da auto estima e do senso de sentir-se apta a empreender novos desafios e descobrir novas potencialidades, mesmo em idade avançada.

Um olhar mais detalhado pode evidenciar que certas atividades são mais prazerosas de serem executadas em relação à outras além de empregarem diferentes níveis de atividade cognitiva. Dentre todas as atividades, o lazer tende a incluir as experiências mais agradáveis do dia pois é durante o lazer que as pessoas se sentem mais motivadas embora possa envolver pouco foco mental, como no caso do lazer passivo, representado especialmente por assistir televisão e a 
socialização, representada por conversas com outras pessoas sem nenhuma outra finalidade que não a própria interação.

Embora possa se pensar que não seja necessário habilidade para se usufruir do tempo livre, pode-se inferir que é mais dificil retirar experiências positivas do lazer do que do trabalho. Isto porque o tempo de lazer que se tem à disposição não irá melhorar a condição de vida, a menos que se saiba como aproveitá-lo de forma substancialmente enriquecedora para a vida.

Por outro lado, o lazer ativo é outra fonte de experièncias muito positivas. A prática de exercicios, hobby e atividades culturais, por exemplo, podem propiciar maior motivação e maior envolvimento com a vida cotidiana porque, em contextos como esse, todas as múltiplas dimensões da experiência são focalizadas com maior intensidade e harmonia umas com as outras.

O fato do lazer ativo não ocupar maior proporção do tempo livre das idosas estudadas pode ser também devido a aspectos individuais, culturais e pelas próprias vicissitudes de suas vidas, onde a própria pessoa não foi preparada para usufruir de forma adequada o próprio ócio. Também pode ter colaborado a falta de oportunidades adequadas de interação e aprimoramento pessoal oferecidas pelo setor público.

O emprego do tempo livre, como o verificado neste estudo, poderia ser direcionado para o aprendizado de alguma atividade educacional, a qual poderia exigir e ao mesmo tempo oferecer as mesmas (ou mais) experiências do lazer ativo. Contudo, nenhuma idosa reportou atividades deste gênero, podendo significar a ausência de circunstâncias favoráveis e incentivo que, culturalmente, é trazida do passado para o tempo presente. Nesta situação, para muitas idosas, há um pensamento unânime de que adquirir saber ou aprender a fazer algo diferente em determinada fase da vida carece de sentido prático e propósito. 
Vale ressaltar o fato de que, para algumas pessoas, muitas vezes o que se considera trabalho pode ser encarado como um lazer ativo, pois encontram em tais atividades um desafio significativo, que exige empenho e habilidade e, portanto, encontram prazer em executá-las.

Lazer é algo subjetivo porque depende do ponto de vista pessoal. Dessa forma, muitas atividades ditas obrigatórias podem ser consideradas como atividades de lazer por algumas pessoas.

Em termos de trabalho remunerado, constatou-se que oito idosas exerciam atividades remuneradas, mas nenhuma tinha registro em carteira.

Embora não se tenha verificado as razões do envolvimento das idosas com atividades remuneradas no mercado informal, presume-se que isso decorra da necessidade de complementação da renda familiar, já que o valor do benefício recebido pela maioria que possui algum tipo de renda eqüivale a um salário mínimo.

Neste estudo, verificou-se que as atividades remuneradas exercidas pelas idosas já faziam parte dos seus contextos de vida (fazer serviços domésticos, culinária, trabalhos manuais, venda de enxovais). Estas atividades, se antes obrigatórias para o bom desempenho doméstico, representam hoje a falta de oportunidade que as mulheres não tiveram no passado em termos de preparação adequada pois, em sua maioria, não tiveram carreiras profissionais, investindo todo seu tempo na criação dos filhos e cuidados com a casa e marido.

Trabalho é uma categoria de atividade ampla que praticamente torna impossível se fazer uma generalização sobre o mesmo pois, o tipo e a qualidade da experiência que se vive depende, em primeiro lugar, do tipo de emprego já que cada atividade implica em menor ou maior investimento de atributos atencionais e emocionais.

Outra caracteristica é que a mesma atividade pode apresentar diversas facetas que podem ser experimentadas de maneiras diferentes pela mesma pessoa. Quanto mais ele se apresenta como uma atividade 
que integra sentimentos e emoções de forma harmônica, maior é o envolvimento, mais positiva é a experiência ou seja, quando há um senso de controle e desafios que correspondem às habilidades do trabalhador com poucas chances de divagações, maior é a importância do trabalho para a vida cotidiana.

Trabalhar pode ser considerada uma atividade ambígua pois, ao mesmo tempo que oferece uma sensação de orgulho e identidade, pode significar algo que muitas pessoas desejaria evitar.

Homens e mulheres experimentam o trabalho de modos diferentes. A identidade do homem com o trabalho se baseia na capacidade de obter recursos do ambiente para sustento seu e da sua família. Para as mulheres, tradicionalmente o trabalho fundamenta-se na sua capacidade de criar um ambiente físico e emocional adequado para cuidar dos filhos e do bem estar dos adultos.

$\mathrm{Na}$ atualidade, mesmo com as mudanças de valores e a conquista de novos espaços por parte das mulheres, ainda é arbitrária a divisão entre o trabalho remunerado e o trabalho doméstico. Além do trabalho fora de casa, à mulher ainda cabe todo o trabalho de manutenção da mesma.

Embora possa ser um fardo pesado, o trabalho tem suas compensações. Além da remuneração, os momentos em que uma pessoa está em uma situação de desafio que exige certa habilidade, junto com sentimentos de concentração, criatividade e satisfação, fazem do trabalho uma atividade intrinsicamente recompensadora. Isto porque, todo trabalho tem metas e regras claras além de oferecer retorno sobre o desempenho de modo a saber se a tarefa foi bem sucedida.

Ter um trabalho pode significar um encorajamento à concentração eliminando em grande parte as distrações. Tem-se também uma quantidade variável de controle porque, em termos ideais, as dificuldades que ele impõe correspondem às habilidades do trabalhador. 
Quando em casa com familiares ou sozinhas, muitas pessoas carecem de uma finalidade clara, não sabendo como está seus desempenhos e, muitas vezes, sentindo que suas habilidades estão sendo subutilizadas, o que pode gerar sentimentos de negatividade e inferioridade.

Para os idosos, ter um trabalho que seja considerado essencial pode faze-los com que se sintam necessários e integrados ao contexto de suas famílias.

Atividades que exigem maior atenção oferecem maior probabilidade de exercicio e aprimoramento das potencialidades individuais. O trabalho se enquadra nesta modalidade porque, em geral, exige o emprego de toda a habilidade e concentração da pessoa além de poder oferecer espaço para criatividade e satisfação.

Em geral, todo trabalho tem um propósito claro e regras definidas. Através de seus resultados, tem-se um feedback de modo que a pessoa tem condições de avaliar seu desempenho e fazer ajustes, se necessário.

Faz-se importante ressaltar também que, infelizmente, nossa sociedade tende a valorizar o trabalho do jovem, por considerá-lo portador de idéias mais criativas e arrojadas, caracteristica essencial no mundo globalizado.

Esta forma de agir coloca o trabalho e o conhecimento da pessoa idosa como obsoletos, desatualizados e em descompasso com a era da informática. Assim, não deve surpreender o fato de que, nas culturas consumistas, ávida pelo novo, a sabedoria acumulada pelos anos de experiência carecem de significado e, ao idoso, muitas vezes resta somente o exercício de atividades simples que podem não contribuir para sua auto estima.

Felizmente, o quadro que se observa para as pessoas idosas, especialmente as mulheres, tende à mudança, na medida em que, com maior longevidade e saudáveis e, mesmo não sendo profissionais 
liberais, elas exercem atividades extra domésticas, participam de grupos e associações, realizam cursos, atividades e viagens especiais.

Desse modo, a visão restrita da idosa como detentora de conhecimento e experiência relacionada somente ao papel de avó está perdendo sentido dado a redescoberta da importância do potencial individual da pessoa idosa para com a família e a comunidade.

Também as restrições econômicas enfrentadas pela sociedade levaram um número maior de mulheres para a força de trabalho e o que se verifica é o número crescente de familias que passaram a depender, parcial ou totalmente, do trabalho feminino (ou de sua aposentadoria) para sua sobrevivência.

Qualquer trabalho, quando abordado sem preconceitos sociais e quando realizado de forma que seja sentido como pessoalmente significativo, pode aumentar a qualidade de vida e o senso de ser útil dentro de determinado contexto. Em outras palavras, não são as condições externas que determinarão o quanto as atividades de trabalho contribuem para a satisfação da vida mas como o individuo trabalha e, principalmente, quais as experiências que ele é capaz de retirar do confronto com os desafios que a atividade impõe.

Um trabalho que muitas vezes foge às características de satisfação mencionadas acima trata-se da atividade de cuidar.

Neste estudo, foi encontrada uma pequena proporção de mulheres que se dedicavam ao trabalho (não remunerado) de cuidadora, tanto de idosos quanto de crianças.

É importante ressaltar a tendência da mulher em habitar um ambiente multigeracional, o que possibilita a função de cuidadora para outras pessoas, tanto do círculo familiar como para terceiros, embora o papel de cuidadora seja exercido, sobretudo, em relação ao marido. Este papel social se contrapõe àquela figura discriminada de pessoa dependente e que se constitui num peso para a família.

Estudos de uso do tempo permitem quantificar o custo do tempo destinado à execução de atividades domésticas e ao trabalho de cuidar 
que, segundo BEDIAKO e VANEK (1998), caso fossem atividades remuneradas, iriam evidenciar a enorme extensão do quanto as mulheres contribuem para a economia de suas familias.

Assim, o cuidar de outro idoso ou do idoso para com os filhos e netos pode ser pensado como um tipo de trabalho desgastante, não remunerado e não registrado que pode levar a mulher a se deparar com problemas de saúde física e mental (GOLDANI, 1999).

O porque da atividade de cuidar ser atribuída á mulher tem as mesmas raizes colocadas anteriormente ou seja, fatores culturais onde há divisões de papéis de gênero socialmente definidas, discriminação e falta de acesso ao ensino e trabalho.

Em resumo, a vida de toda pessoa consiste de experiências relacionadas ao trabalho, manutenção e lazer (CSIKSZENTMIHALYI (1999) e é dentro desses parâmetros que a vida cotidiana se desdobra.

$O$ perfil das atividades secundárias mostraram que o trabalho, manutenção e lazer são realizados enquanto atividade única ou então são permeados por conversas com determinados parceiros sociais. Um dos motivos para maior proporção de não realização de atividade secundária em paralelo à uma atividade principal pode significar que esta última, pela sua natureza, não permitia a simultaneidade.

Dedicar-se mais intensamente à execução de uma tarefa pode indicar o estabelecimento de uma meta e o tempo e grau de envolvimento com a mesma dependem da motivação individual e da necessidade em realizá-la.

As metas nas quais se investe atenção durante a vida, além de colocarem uma ordem nas experiências cotidianas, formarão e determinarão o tipo de pessoa na qual o individuo se transformará.

Deve-se ter em mente que, na vida cotidiana, nem sempre os diferentes conteúdos da experiência estão sincronizados uns com os outros porque pensamentos, intenções e emoções podem estar atuando em sentidos contrários. Por exemplo, pode-se, ao mesmo tempo, ter a atenção focalizada no trabalho mas não estar totalmente envolvido 
nele por ser uma atividade que não se aprecia e, ao mesmo tempo, ter sentimentos de ansiedade com relação a algo que naquele momento nos preocupa. Assim. o sentir, desejar e pensar nem sempre se encontram harmonizados no dia-a-dia ao se executar as atividades porém, quando isto ocorre, pode-se dizer que a vida torna-se significativa.

Em relação ao contexto físico, os resultados mostraram que a vida cotidiana tem lugar em vários ambientes como a casa, o supermercado, a rua, o transporte.

Além das atividades e das companhias, o espaço físico também tem efeito sobre a qualidade com que se vivência o dia-a-dia. Determinados espaços públicos podem facilitar ou restringir os comportamentos já que estes últimos, por norma, devem corresponder às expectativas sociais.

Adultos talvez prefiram lugares onde possam exercer com maior liberdade atividades de caráter voluntário ou seja, espaços onde a expressão da individualidade possa ocorrer de forma mais natural. Isso talvez seja verdadeiro para mulheres onde sair de casa pode significar um alivio da rotina diária e oportunidade de ocorrência de novas e diferentes interações.

Nesse estudo, tal aspecto pode ser evidenciado pela proporção (embora pequena) de atividades realizadas fora do ambiente doméstico, em especial em outro imóvel privado, representado pelas residências de amigas.

Por outro lado, deve-se considerar que a própria casa, muitas vezes, se constitui em espaço de predileção única e que também seus diferentes setores podem apresentar um perfil emocional peculiar porque cada ambiente é destinado à execução de atividades diferentes podendo gerar sensações diferentes.

Assim, é de se esperar que muitas idosas sintam-se seguras e confortáveis usufruindo integralmente do seu ambiente doméstico e isto pode ser evidenciado pela alta porcentagem de atividades realizadas na própria casa. Tal sensação de conforto também pode ser 
atribuida ao fato de todas as idosas estudadas residirem em imóvel próprio, isentando a elas ou a família do pesado fardo de despesas com aluguel.

Estes resultados sugerem semelhanças com os de BENNETT (1998), que menciona uma proporção maior de atividades realizadas no ambiente doméstico, mostrando a influência do gênero na distribuição das atividades em relação ao contexto físico da pessoa idosa.

Também sugerem semelhantes com estudos de BALTES e colaboradores (1990), que evidenciaram uma maior proporção de atividades realizadas no ambiente doméstico, fazendo deste espaço o dominio geográfico por excelência na vida diária do idoso, principalmente da mulher.

Uma outra caracteristica principal da vida cotidiana é o entrar e sair do estado de solidão ou seja, o contexto social das atividades.

A vida cotidiana não é somente definida por aquilo que se faz mas também por aqueles que se fazem presentes durante a ação. Assim, o sentimento e o agir do indivíduo sofre influências de outras pessoas, estejam elas presentes ou não.

Estar só pode comprometer a motivação, concentração, auto estima e levar á uma seqüencia de estados negativos como passividade, apatia e distanciamento. Provavelmente tal quadro se apresente com maior frequência entre pessoas com menores recursos materiais, educacionais, solteiras ou viúvas.

A solidão, aliada a nenhuma atividade ou atividade rotineira, pode ocupar a mente com pensamentos deprimentes levando entropia para dentro da consciência pois não há objetivo válido no qual concentrar a atenção. Contudo, quando se interage com o outro, a atenção torna-se estruturada devido às exigências externas ou seja, a presença do outro impõe metas e oferece um feedback do desempenho. 
Mesmo interações simples tem seus próprios desafios que são confrontados com as habilidades pessoais, exigindo um investimento ordenado de energia psiquica. Relacionar-se melhora a qualidade de vida pois encontra-se naquele com quem se partilha os problemas um referencial de apoio emocional e estimulo.

A maioria das pessoas vive períodos de tempo distribuídos em contextos sociais caracteristicos. Um deles é formado por estranhos, amigos ou colegas e é neste espaço que os atos do individuo são avaliados pelos outros, onde se compete por recursos atencionais e onde é possivel estabelecer relacionamentos de cooperação.

Neste estudo, o tempo partilhado com amigos ou outras pessoas foi muito menor em relação à outros parceiros sociais.

Possiveis explicações poderiam ser que, neste tipo de situação, as exigências relacionais e os riscos seriam maiores, impondo talvez o medo de ser rejeitado pelo outro ou então a dificuldade em permitir a criação de um espaço para acolher o outro e suas diferenças. Mas é neste tipo de convivencia que poderia ser verificado um maior crescimento individual pois, de todas as coisas que normalmente a pessoa faz, a interação com os outros é a menos previsivel.

A familia forma o outro contexto social, em tese mais seguro, onde se estabelece laços de proximidade e responsabilidade mútuos.

Neste estudo, a família e o marido representaram os contextos sociais mais freqüentes para a realização das atividades diárias, podendo indicar um relacionamento intergeracional presente e muito importante para o suporte do idoso, pois pode prover uma troca permanente de assistència entre seus membros.

Já a solidão, o segundo contexto social mais presente entre as idosas, implica num modo de vida onde é necessário aprender a conviver pois, muitas vezes, estar só não se constitui numa opção mas sim algo "adquirido" e adaptar-se à ela é fundamental para a qualidade de vida. 
De certa forma, o bem estar está ligado à qualidade dos relacionamentos que se constrói ao longo da vida. O processo de socialização que ocorre ao longo de estágios sucessivos, pode ser verificado através das respostas que a pessoa recebe dos pares com quem convive.

Para um relacionamento ser bem sucedido entre pessoas que interagem, faz-se necessário a existência de certa compatibilidade entre seus objetivos e também o investimento de certa quantidade de atenção para com os objetivos do outro. Quando essa situação se processa, tem-se um relacionamento de igualdade, formando a base para uma amizade recompensadora no presente como também para o futuro.

Muitas das atividades cotidianas são agradáveis somente por curto período de tempo porque os desafios situacionais que as mesmas impõem logo se esgotam. Por outro lado, relacionamentos duradouros tem o mérito de oferecer um estímulo contínuo durante toda a vida, aprimorando as habilidades emocionais e intelectuais da pessoa.

Provavelmente o padrão tradicional das amizades, onde a pessoa permanecia a maior parte da vida em contato com amigos de infância, não será totalmente possivel porque, infelizmente, a vida moderna não favorece a sustentabilidade de amizades duradouras devido à grande mobilidade geográfica ou social das pessoas.

Tal mudança de padrões relacionais pode se tornar presente dentro da própria familia e, principalmente, na comunidade onde a pessoa idosa vive. Assim, a falta de amigos verdadeiros torna as amizades mais efêmeras e superficiais. Isto poderá se tornar um aspecto negativo de grande monta na velhice na medida em que pode interferir diretamente na rede de suporte social, onde o amparo ou alguma assistência á pessoa idosa por parte de pessoas próximas pode não ser possível.

Neste sentido, concordamos com VOLZ (2000), para quem um aspecto fundamental do envelhecimento bem sucedido é a necessidade 
de ter relacionamentos verdadeiros com outras pessoas pois a qualidade dos mesmos pode influir diretamente na saúde física e mental do idoso.

Os resultados deste estudo inicialmente mostraram idosas executando atividades normais e rotineiras, de forma identica à todo o contingente populacional.

Porém, uma visão mais detalhada permitiu verificar, mesmo em pequena escala, que as idosas vivem em diferentes ambientes e estilos de vida e, o mais importante a ser considerado e o que faz a diferença, é a triade formada pela história pessoal, personalidade e experiências sociais de cada uma delas. Cada vida, única, transita na interface da diversidade e da peculiaridade.

Se observados alguns parâmetros dentro do qual as mesmas conviveram ou seja, com pouca ou nenhuma instrução, sem trabalho remunerado, sem opções de escolhas e somente voltadas ao cumprimento de um papel social imposto, tem-se um quadro dos limites dentro dos quais suas vidas, tão distintas, foram construidas.

Limites tão estreitos, em geral levam à uma inércia, criada a partir do hábito que, junto com as estruturas sociais, constituem-se em fortes elementos que mascaram $e$ podem confundir o discernimento sobre quais componentes do estilo de vida são mais apreciados e quais contribuem para estados de desânimo e depressão.

A partir de uma reflexão sobre quais atividades produzem pontos fortes e fracos do dia, é possível aumentar a frequência dos pontos positivos e diminuir ou lançar nova ótica sobre a realização dos demais.

Assim, a partir de um diagnóstico das atividades diárias e do levantamento de quais atividades se constituem em fonte de maior prazer e realização, é possivel fazer intervenções, coletivas ou personalizadas, com o objetivo de mudar os padrões de atividades, melhorando o bem estar da pessoa. 
Do ponto de vista individual, o primeiro passo para melhorar a qualidade da vida cotidiana consiste em organizar e reestruturar as atividades diárias de modo a extrair delas as experiências mais recompensadoras porque, para se atingir um crescimento verdadeiramente real, é necessário o engajamento em atividades que sejam interessantes e estimulantes.

Também uma abordagem mais qualitativa atribuindo mais importância às caracteristicas sociais, culturais, econômicas e afetivas das idosas é fundamental para se compreender melhor os comportamentos observáveis desta população e realizar as intervenções possiveis e necessárias para gerar melhor qualidade de vida á este grupo populacional.

Embora não tenha sido objetivo deste trabalho analisar a classificação de atividades para uso do tempo e a forma de obtenção dos dados, alguns comentários se fazem necessários.

Neste trabalho foi utilizada a forma de apresentação mais simples da classificação ou seja, somente seus grupos principais de atividades. Isto porque, utilizá-la em toda a sua profundidade e complexidade com um grupo pequeno não teria sentido prático.

Contudo, se utilizada para classificar um contingente maior de pessoas idosas, faz-se necessário, antes, verificar determinados grupos de atividades principais e suas atividades relacionadas (atividades secundárias, podendo até existir subgrupos de atividades secundárias).

Isto se faz necessário para verificar se todas as atividades dos idosos encontram-se representadas em niveis mais detalhados e variados. Tal variedade se faz necessária porque são nos subgrupos das atividades secundárias que se introduz atividades específicas da cultura, população ou grupo e também de atividades que se deseja obter um conhecimento mais detalhado.

$\mathrm{Na}$ escala, no seu nível mais complexo, dentro do grupo de atividades de cuidados pessoais, há um código destinado a classificar 
atividades para as quais as pessoas se reportam como "privadas" ou "particulares".

$\mathrm{Na}$ prática. durante a coleta de dados, foi dito às idosas que, caso não desejassem referir-se diretamente a esses tipos de comportamentos, que mencionassem apenas tratar-se de assunto privativo ou particular.

Em geral, a primeira idéia que se apresenta é a de que tais atividades referem-se apenas ao aspecto sexual ou das necessidades fisiológicas quando, na verdade, envolvem uma ampla gama de situações.

Dessa forma, o estudo não captou atividades ou situações que fazem parte do universo intimo da idosa e que poderiam evidenciar muito do seu contexto afetivo. Provavelmente o receio em expor particularidades da vida numa entrevista para uma pessoa que the é totalmente estranha foi o fator que mais contribuiu para esse fato.

Outro aspecto a ser mencionado refere-se ao recordatório das atividades. Como mencionado na revisão de literatura, o método escolhido para registro das atividades deve atender o melhor possível os objetivos da pesquisa e garantir o máximo possivel a precisão das informações.

Neste trabalho optamos pelo uso do diário, realizado sob forma de entrevista face a face porque, dessa forma, foi possivel auxiliar a idosa a recordar atividades e contextos que, num primeiro momento, passaram despercebidas.

$\mathrm{Na}$ prática, foi possivel constatar que procedem as colocações de STINSON (1999) quando menciona que as pessoas tendem a recordar somente as atividades que foram mais significativas e, além disso, quando são responsáveis pela confecção do próprio diário, registram de modo precário as atividades secundárias.

Outro aspecto a ser considerado é a própria capacidade de recordar das idosas. Embora todas tenham apresentado escores normais no teste de cognição, o tipo de método adotado tornou a entrevista 
mais flexivel na medida em que as auxiliou a descrever, da melhor forma possivel, toda a dimensão contextual do dia recordado. 


\section{CONCLUSÕES}

O estudo permitiu concluir que:

- a vida cotidiana das idosas tem como uma de suas caracteristicas a diversidade, dentro de um universo restrito, e esta pode ser observada sob forma de diferentes comportamentos externalizados durante a realização das atividades cotidianas;

- o perfil das idosas apresenta baixo nivel de escolaridade, escassos recursos financeiros, todas residindo em imóvel próprio e expressiva parcela morando com pelo menos uma pessoa;

- atividades domésticas ocuparam a maior parte do dia, indicando a predominância de atividades de cunho obrigatório;

- dentre os grupos de atividades principais, o lazer ocupou a segunda colocação, sendo que assistir televisão se constituiu na principal atividade de lazer (passivo) do grupo;

- a incorporação de novos papéis sociais como o trabalho remunerado, exercido no âmbito informal, foi um aspecto presente;

- verificou-se participação reduzida em atividades sociais e também baixa participação em atividades físicas (esportivas) nos dias úteis;

- o contexto físico predominante para realização das atividades diárias foi a própria casa;

- o contexto social evidenciou maior interação entre membros da familia. 


\section{RECOMENDAÇÕES}

Mesmo considerando as limitações determinadas pelos ajustes no uso da classificação das atividades de uso do tempo (Time Use Activity Classification), o estudo foi efetivo em mostrar o cotidiano de um grupo de mulheres idosas, bem como o ambiente físico e seus parceiros sociais.

Esta conclusão desvela a possibilidade de se efetuarem estudos de uso do tempo conduzidos, como vimos, de forma simples, em curto espaço de tempo e com resultados mais adaptados à realidade dos nossos serviços de assistência primária.

Ao contrário das escalas de atividades básicas e instrumentais da vida diária que avaliam a pessoa idosa com base na investigação de parâmetros físicos, este tipo de estudo permite identificar a heterogeneidade do universo ocupacional ao levar em consideração as distintas experiências do envelhecimento que, por sua vez, influenciam a qualidade de vida destas pessoas.

Considerando uma sociedade com inúmeros contrastes, sobretudo econômico, social e cultural, quando realizado em sua forma simples e com grupos menores, o estudo permite um diagnóstico mais rápido, específico do ambiente e do estilo de vida dos mesmos, permitindo orientar as intervenções e recursos que são possíveis e que se encontram disponíveis, dentro da realidade da própria comunidade ou do município, e que podem ser implantados em curto prazo.

Como exemplo, neste estudo verificou-se a participação reduzida em atividades sociais, podendo indicar que algumas idosas encontram-se num quadro de isolamento social. Da mesma forma, a baixa participação em atividades físicas (esporte) poderá trazer, a longo prazo, limitações nos niveis de independência das idosas. 
O diagnóstico acima remete à necessidade de aplicação de conhecimentos, técnicas e métodos de trabalho de outras áreas profissionais interagindo com o intuito de promover o melhor bem estar possivel da pessoa idosa, retardando o surgimento de situações incapacitantes.

SOBRAL (1996) sugere que equipes multidisciplinares trabalhem na prevenção e atenção à pessoa idosa de forma progressiva, numa espécie de contimuım, iniciando com a atenção comunitária, através de práticas sociais integradas.

O que se pretende são intervenções que extrapolem o enfoque puramente clínico, que ampliem esta abordagem com o objetivo de fazer com que idosos se conscientizem de que saúde, bem estar físico e mental necessitam de participação individual integral. Em outras palavras, busca-se instrumentalizar a pessoa com conhecimentos suficientes e sempre atualizados, para que possa exercer o autocuidado de forma mais efetiva (SAYEG, 1998).

Já um trabalho mais abrangente sobre o uso do tempo seria importante, pois permitiria verificar, além do cotidiano das mulheres idosas, a influência de fatores individuais como idade, gênero, grau de instrução, estado civil e nível sócioeconômico sobre a realização das atividades diárias. Juntamente com a pesquisa sobre o uso do tempo, outros instrumentos de análise poderiam ser utilizados para que a população fosse melhor caracterizada.

Além disso, um estudo dessa natureza, realizado sob padrões de comparabilidade internacional e acrescido da pesquisa de outras variáveis além das individuais, possibilitaria o conhecimento do cotidiano tanto de homens e mulheres idosas, vivendo sob as condições da realidade e diversidade brasileiras, bem como a comparação entre populações ou grupos de diferentes países, em condições semelhantes.

Considera-se ainda que, os resultados de um estudo mais amplo poderiam, mais efetivamente, ser úteis para direcionar a elaboração de 
políticas públicas voltadas à população que envelhece, bem como apontar áreas em que a demanda por assistencia e serviços são mais prementes, com o objetivo de prevenir ou retardar a dependência neste grupo, conforme já mencionado.

Outra finalidade deste tipo de pesquisa seria sua realização sistemática, o que permitiria acompanhar tendências e trajetórias do envelhecimento de e entre homens e mulheres de diferentes gerações ao longo do tempo. 


\section{REFERÊNCIAS BIBLIOGRÁFICAS}

Albert, S. M. Time and function. In: Rubistein, R. L., Moss, M. \& Kleban, M. H. (Eds.) The many dimensions of aging. New York, Springer Publishing Company, 2000, p.57-67.

Alvarez, M. D. \& Mering, O. V. Aging, demography, and well being in Latin America: proceedings of an international conference. Center for Gerontological Studies, University of Florida and International Exchange Center on Gerontology of University of South Florida, 1989.

Amaral, R. C. Povo-de-santo, povo de festa. Estudo antropológico do estilo de vida dos adeptos do candomblé paulista. São Paulo; 1992. [Dissertação de Mestrado - Faculdade de Filosofia, Letras e Ciências Humanas da USP].

(AGS) American Geriatrics Society Older women's health task force on older women's health. JAGS, 1993, 41: 680-83.

Ankri, J. Prevention of loss of functional independence and institutionalization. Presse Med, 2000 Jun, 24 (22): 1255-62. Disponivel em: <URL:http://www. ncbi.nlm.nih.gov/entrez/query $>$ [Setembro 2001].

Ashworth, J. B., Reuben, D. B. \& Benton, L. A . Functional profiles of healthy older persons. Age Ageing, 1994, 23 (1): 349. Dusponivel em: < URL:http://www. ncbi.nlm.nih.gov/entrez/query $>$ [Setembro de 2001]. 
Atchley, R. A continuity theory of normal aging. The Gerontologist, 1989, 29 (2): 183-90.

Australian Bureau os Statistics Time use survey, Australia. Confidentialist unit record file (information paper). Canberra, 1999 (ABS Catalogue n 415.0).

Baltes, M. M., Mayr, U., Borchelt, M., Maas, I. \& Wilms, H. U. Everyday competence in old and very old age: an interdisciplinary perspective. Ageing and Society, 1993, 13: 657-80.

Baltes, M. M., Wahl, H. W \& Furstoss, S. The daily life of elderly Germans: activity patterns, personal control, and functional health. J Gerontol, 1990 Jul, 45: 173-9. Disponivel em: <URL:http://www ncbi.nlm nih gov/entrez/query> [Janeiro $2003]$.

Baltes, P. B. The aging mind: potential and limits. The Gerontologist, 1993, 33 (5): 580-94.

Bediako, G \& Vanek, J. Trial international classification of activities for time-use-statistics. [Apresentado na International Conference on Time Use, 22-25 April 1998, University of Luneberg].

Bennett, K. M. Gender and longitudinal changes in physical activities in later life. Age Aging, 1998 Dec, 27:24-8. Disponivel em: $\quad$ URL:http://www.ncbi.nlm.nih. gov/entrez/query $>$ [ Setembro 2001]. 
Bennett, K. M. Low level social engagement as a precursor of mortality among people in later life. Age Aging, 2002 May, 31 (3): 165-8. Disponivel em: <URL:http://www.ncbi.nlm.nih. gov/entrez/query> [ Janeiro 2003].

Berqüo, E. Algumas considerações demográficas sobre o envelhecimento da população no Brasil. [Trabalho preparado para o Seminário Internacional sobre o Envelhecimento Populacional: uma agenda para o fim do século; 1996 junho 1-3; Brasília, Brasil].

Blain, H., Vuillemin, A . Blain, A. \& Jeandel, C. The preventive effects of physical activity in the elderly. Presse Med, 2000 Jun, 29 (22): 1240-8. Disponível em: <URL:http://www. ncbi.nlm.nih gov/entrez/ query> [Setembro 2002].

Bourdieu, P. Gostos de classes e estilos de vida. In: Ortiz, R., organizador. Bourdieu. Coleção Grandes Cientistas Sociais. $N^{\circ}$ 39, São Paulo: Àtica; 1983.

Bowling, A. Measuring health: a review of quality of life measurement. Great Britain, Biddles Limited, 1992.

Branch, L.G., Horowitz, A \& \& Carr, C. The implications for everyday life of self reported visual decline among people over age 65 living in the community. The Gerontologist, 1989, 29: 359-65.

Brasil. Política Nacional de Saúde do Idoso: lei 8.842 de 04 de janeiro de 1994. Brasília: Ministério da Previdencia e Assistência Social; 1996. 
Braudel, F. The structures of eveyday life. (vol.1). Berkley, University of California Press, 1992.

Carp, F. M. Effects of the living environment on activity and use of time. Int Journal Aging and Human Development, 1978, 9 (1): 75-91. Ddisponivel em: <URL:http://www. ncbi.nlm.nih.gov/entrez/query $>$ [Setembro 2001].

Chaimowicz, F. A saúde dos idosos brasileiros às vésperas do século XXI: problemas, projeções e alternativas. Revista de Saúde Pública [periódico online] 1997, 31 (2); Disponivel em

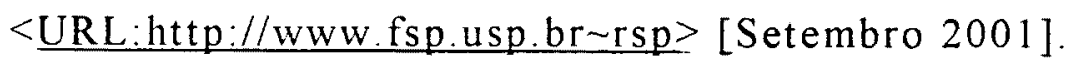

Chaimowicz, F. Os idosos brasileiros no século XXI demografia, saúde e sociedade. $1^{\circ}$ ed., Belo Horizonte: Postgraduate; 1998.

Checkoway, B. Empowering the elderly: gerontological health promotion in Latin America. Ageing And Society, 1994, 14: 7595.

Crowther, M. Parker, M. W., Achenbaum, W. A ., Larimore, W. L. \& Koenig, H. G. Rowe and Kahn's model of successful aging revisited: positive spirituality - the forgotten factor. The Gerontologist, 2002, 42 (5): 613-20.

Csikszentmihalyi, M. A descoberta do fluxo: a psicologia do envolvimento com a vida cotidiana. Rio de Janeiro, Rocco; 1999. 
Da Silva, M. J. \& Varela, Z. M. V. O conceito de adaptação na terceira idade: uma aproximação teórica. Arq Geriatr Gerontol, $1999,3(1): 25-9$.

Daley, M. J. \& warwick, 1. s. Exercise, mobility and aging. Sports Med, 2000, 29 (1): 1-12.

Derntl, A . M. As muitas autonomias e o autocuidado. Gerontologia, 1998, 6 (4): 197-99.

Diehl, M. Everyday competence in later life: current status and future directios. The Gerontologist, 1998, 38 (4): 422-33.

Duffy, M. \& MacDonald, E. Determinants of functional health of older persons. The Gerontologist, 1990, 30 (4): 503-09.

Evans, J.G. Prevention of age-associated loss of autonomy: epidemiological approaches. Journal of Chronic Diseases, $1984,37(5): 353$.

Ezzell, C. Tempo e cultura. Scientific Americam Brasil, 2002, ano $1,5: 86-7$.

Farinatti, P.T. Avaliação da autonomia do idoso: definição de critérios para uma abordagem positiva a partir de um modelo de interação saúde-autonomia. Arquivos de Geriatria e Gerontologia, 1997,1 (1): 31-7.

Ferrari, M. A . C. O envelhecer no Brasil. O Mundo da Saúde, 1999,23 (4): 197-203. 
Fleck, M. P. A , Louzada, S., Xavier, M., Chachamovich, E., Vieira, G., Santos, L \& Pinzon, V. Aplicação da versão em portugüês do instrumento abreviado de avaliação da qualidade de vida "WHOQOL-bref". Revista de Saúde Pública. 2000; 34 (2): $178-83$.

Fleming, R. \& Spellerberg, A . Using time use data: a history of time use surveys and uses of time use data. Wellington, New Zealand: Statistics New Zealand; 1999 (Catalogue $n^{\circ}$ $04.021 .0098)$

Fries, J. F. Aging, natural death, and the compression of morbity [especial article]. N. Engl J Med., 1980, 303:130-5.

Fundação IBGE. Pesquisa nacional por Amostra de Domicílios - 1995. Brasil. Disponivel em <URL:http://www. Ibge.gov.br/pnad/an0-1995/brasil/indice.htm> [Março1996].

Fundação IBGE. Censo demográfico: resultados preliminares - São Paulo. Brasil. Disponivel em <URL:http://www. Ibge.gov.br $>$ [Setembro 2001]

Fundação SEADE. São Paulo em dados. [on line]. Disponível em $<\underline{\text { http: } / / w w w . s e a d e . g o v . b r}>$ [Março 1999].

Gauthier, A . H \& Smeeding, T.M. Patterns of time use if people age 55 to 64 years old: some cross-national comparisons. Syracuse, New York. Center for Policy Research, Maxwell Scholl of Citizenship and Public Affairs, 2000, (Aging Studies Program Paper $\left.n^{\circ} 20\right)$. 
Gershuny, J. Time budget research in Europe. Meeting of the Party on Social Indicators, 23 March, 1992 (Eurostat, Luxemburg. DOC E3/IS/5/92)

Giger, J. N., Davidhizar, R. \& Poole, V. Growing older is not what it used to be. Health Care Superv, 1998 Jun, 16 (4): 40-7. Disponivel em: <URL:http://www. ncbi.nlm.nih gov/entrez/query $>$ [Setembro 2001]

Gil, A.C. Métodos e técnicas de pesquisa social. $2^{\circ}$ ed., São Paulo: Editora Atlas S.A.; 1989.

Goldani, A. M. Mulheres e envelhecimento: desafios para novos contratos intergeracionais e de gênero. In: Camarano, A. A. organizadora. Muito além dos sessenta. Os novos idosos brasileiros. Rio de Janeiro: IPEA, Instituto de Pesquisa Aplicada, 1999, 75-114.

Goldstein, L.L.\& Siqueira, M. E. C. Heterogeneidade e diversidade nas experiências da velhice. In: Neri, A .L. \& Freire, S. A organizadoras. E por falar em boa velhice. Campinas: Papirus, 2000, 113-24.

Goode, W. J \& Hatt, P. M. Métodos em pesquisa social. $4^{\circ}$ ed.. São Paulo: Companhia Editora Nacional, 1973

Grigsby, J. S. The meaning of heterogeneity: na introduction. The Gerontologist, 1996, 36 (2): 145-46.

Grimley-Evans, J. Prevention og age associated loss of autonomy epidemiological approaches. J Chron Dis, 1984, 37 : 353-63. 
Hanson, S. \& Hanson, P. The geography of everyday life. In: Garling, T. \& Colledge, R. C. (Eds) Behavior and environment: psychological and geographical approaches. Oxford, Elsevier Science, 1993, p.249-69.

Heller, A. O cotidiano e a história. 2ed., Rio de Janeiro, Editora Paz e Terra, 1985.

Hirvensalo, M., Rantanen, T. \& Heikkenen, E. Mobility difficulties and physical activity as predictors of mortality and loss of independence in the community-living older population. J Am Geriatr Soc, 2000 May, 48 (5): 493-8. Disponível em: <URL:http://www. ncbi.nlm.nih.gov/entrez/query> [Setembro $2001]$.

Horgas, A . L.; Wilms, H.U. \& Baltes, M.M. Daily life in very old age: everyday activities as expression of successful living. The Gerontologist, 1998, 38 (5): 556-68.

Hubert, H. B., Bloch, D. A ., Oehlert, J. W., Fries, J. F. Lifestyle habits and compression of morbidity. J.Gerontol Med Sci, 2002; 57 A(6): M347-51.

Huyck, M. H. gender differences in aging. In: Birren, J. E. \& Schaie, K. W. (Eds.) Handbook of the psychology of aging. Academic Press, USA, 1990, p. 124-31. 
Iwasaki, Y., Zuzanek, J.,Mannell, R. C. The effects of physically active leisure on stress-health relationships. Can J Public Health, 2001 May, 92 (3): 214-18. Disponivel em: <URL:http://www. ncbi.nlm.nih.gov/entrez/query> [Janeiro 2003].

Joyce, M. \& Stewart, J. What can we learn from time-use data? Montly Labor Review, August 1999, 3-6.

Kalache, A., Veras, R.P. \& Ramos, L.R. O envelhecimento da população mundial: um desafio novo. Revista de Saúde Pública, 1987, 21(3): 200-10.

Katz, S., Ford, A. B., Moskowitz, R. W., Jackson, A. B., \& Jaffe, M. W. Studies of illness in the aged. JAMA, 1963, Set., 21: $94-9$.

Khaw, K. T. Epidemiological aspects of ageing. Philos Trans $R$ Soc Lond B Biol Sci, 1997 Dec, 352 (1363): 1829-35. Disponível em: <URL:http://www.ncbi.nlm.nih.gov/entrez/ query [Setembro 2001].

Kirkwood, T. Os melhores anos de nossa vida. Rio de Janeiro, Record, 2001.

Kruse, A . \& Wahl, H. W. Social relationships. Z Gerontol Geriatr, 1999 Oct, 32 (5): 333-47. Disponível em: $<\underline{\text { URL:http://www.ncbi.nlm.nih.gov/entrez/ query }>\text { [Janeiro }}$ $2003]$.

Lawton, M. P. Environment and other determinants of well being in older people. The Gerontologist, 1983, 23 (4): 349-57. 
Lawton, M. P \& Brody, E. M. Assessment of older people: self maintaining and instrumental activities of day living. The Gerontologist, 1969, 9:179.

Lawton, M. P., Moss, M. \& Fulcomer, M. Objective and subjective uses of time by plder people. Intern. Journal of Aging and Human Development, 1986, 24: 171-88.

Lawton, M. P. \& Nahemow, L. Ecology and the aging proces. In: Eisdorfer, C. \& Lawton, M. P. (Eds.) The psychology of adult development and aging, Washington, American Psychological Association, 1973, p.619-74.

Manell, R .C Older Adults, leisure, and wellness. Journal of Laisurability, 1999, 26 (2): 1-6.

Maslow, A. H. A theory of human motivation. In: Vroom, V. H. \& Deci, E. L. (Eds) Management and motivation. Great Britain, Richard Clay Ltd., 1970.

Matsudo, S. M., Matsudo, V. K. R. \& Barros Neto, T. L. Impacto do envelhecimento nas variáveis antropométricas, neuromotoras e metabólicas da aptidão física. Revista Brasileira de Ciência e Movimento, 2000, 8 (4): 21-32.

Medeiros, S. L. Saúde e qualidade de vida na opinião dos idosos. Gerontologia, 1994, 2 (1): 07-12. 
Mendes de Leon, C. F. Seeman, T. E., Baker, D. I.. Richardson, E. D. \& Tinetti, M. E. Self-efficacy, physical decline, and change in functioning in commmunity-living elders: a prospective study. Journal of Gerontology, 1996, 51B: S18390.

Moss, M. S. \& Lawton, M. P. Time budgets of older people: a window on four lifestyles. Journal of Gerontology, 1982, 37 (1): $115-23$

Moura, R. N., Santos, F. C., Driemeier, M., Santos, L. M. \& Ramos, L. R. Quedas em idosos: fatores de risco associados. Gerontologia, 1999, 7 (2): 15-21.

Nahemow, L. The ecological theory of aging: Powell Lawton's legacy. In: Rubistein, R. L., Moss, M. \& Kleban, M. H. (Eds.) The many dimensions of aging. New York, Springer Publishing Company, 2000, p.22-40.

Neri, A L. Palavras-chave em gerontologia. Campinas: São Paulo, Editora Alínea, 2001.

Onder, G., Penninx, B. W. J. A ., Lapuerta, P., Fried, L., Ostir, G. V., Guralnik, J. M. \& Pahor, M. Change in physical performance over time in older women. J Gerontol Series A: Biol Sci Med Sci, 2002, 57: M289-93.

(OMS) Organização Mundial da Saúde. Saúde das pessoas idosas. Resolução CE122.R9, 1998.

(OMS) Organização Mundial da Saúde. Dia mundial da saúde. Dacumento. 1929. 
(OMS) Organization Mundial de la Salud. El envejecimiento y la capacidad de trabajo. Serie de Informes Tecnicos 835, Ginebra, 1993.

(OPS) Organização Panamericana de Saúde. $25^{\circ}$ Conferência Sanitária Pan-Americana. Saúde dos Idosos: envelhecimento e saúde: um novo paradigma. CSP $25 / 12$ (Port.), Julho 1998.

(OPS) Organization Panamericana de la Salud. La atencion de los ancianos: un desafio para los años noventa. Washington (DC); 1994. (OPAS - Publicacion Cientifica $\mathrm{n}^{\circ} 546$ ).

(OPS) Organização Panamericana de Saúde. $2^{\circ}$ Conferência Sanitária Pan-Americana. Saúde e Envelhecimento. CSP26/13 (Port.), Julho 2002.

Pacheco, J.L. Práticas sociais na promoção da saúde do idoso. Arquivos de Geriatria e Gerontologia, 1997, 1 (2): 79-82.

Paschoal, S.M.P. Autonomia e independência. In: Papaleo Netto, M. Gerontologia. São Paulo, Ed. Atheneu, 1997, p. 313 23.

Paula, J.A.M., Tavares, M.C.G.C.F. \& Diogo, M. J.D. Avaliação funcional em gerontologia. Gerontologia, 1998, 6 (2): $81-88$.

Pescatello, L.S. \& DiPietro, L. Physical activity in older adults - na overview of health benefits. Sports Medicine, 1993, 15 (6): 353-64. 
Pinquart, M. \& Sörensen, S. Influences of socioeconomic status, social network, and competence on subjective well being in later life: a meta-analysis. Psychology and Aging, 2000, 15 (2): 187-224.

Polit, D. F. \& Hungler, B. P. Nursing research: principles and methods. 3 ed. Philadelphia: Lippincott Company; 1989.

Rahaman, O ., Strauss, J., Gertler, P., Ashley, D. \& Fox, K. Gender differences in adult health: na international comparison. The Gerontologist, 1994, 34 (4): 463-9.

Ramos, L. R., Toniolo, J. N., Cendoroglo, M. S., Garcia, J. T., Najas, M. S., Perracini, M. et al. Estudo de seguimento por dois anos de idosos residentes em São Paulo, Brasil: metodologia e resultados preliminares.. Revista de Saúde Pública [periódico on line] 1998, 32 (5); Disponivel em <URL:http:/ /www.fsp.usp.br/ rsp> [Novembro 2001].

Rauchbach, R. Exercício- saúde - envelhecimento. O Mundo da Saúde, 1998, 22 (4): 216-21.

Rose, G. The strategy of preventive medicine. New York: Oxford University Press; 1992.

Rowe, J. W \& Kahn, R. Human aging: usual and successful. Science, 1987, 237:143-9.

Sayeg, M.A. Envelhecimento bem sucedido e o autocuidado: algumas reflexões. Arquivos de Geriatria e Gerontologia, 1998, 2 (3): 96-8. 
Salthouse, T. A . Cognitive competence and expertise in aging. In: Birren, J. E. \& Schaie, K. W. (Eds.) Handbook of the psychology of aging. 3 ed., Los Angeles, Academic Press, 1990, p.310-19.

Selltiz, Jahoda, Deutch \& Cook Métodos de pesquisa nas relações sociais. Trad. D. M. Leite, São Paulo: Editora Herder; 1965 .

Schneider, E. L. \& Brody, J. A . Aging, natural death, and the compression of morbity: another view [sounding board]. N Eng J Med, 1983, 309: 854-6.

Shepard, R. J. Exercise and aging: extending independence in older adults. Geriatrics, 1993 May, 48 (5): 61-4. Disponivel em: <URL:http://www.ncbi. nlm.nih.gov/entrez/ query [Setembro 2001].

Silvestre, J.A ., Kalache, A ., Ramos, L.R. \& Veras, R P. O envelhecimento populacional brasileiro e o setor de saúde. Arquivos de Geriatria e Gerontologia, 1996, 0 (1): $81-9$.

Sin, A.L., Beers, M.H. \& Morgenstern, H. The geriatric "medical and public health" imperative revisited. Journal American Geriatr. Soc., 1993, 41: 78.

Sobral, B. Instâncias de intervenção em saúde do idoso. Arquivos de Geriatria e Gerontologia da SBGG, 1996, 0 (1):55-7. 
Stahelin, H. B. Social competence and ability to make decisions. Ther Umsch, 1997 Jun, 54 (6): 356-60. Disponivel em: <URL:http://www.ncbi. nlm.nih.gov/entrez/ query [Setembro $2001]$.

Statistics New Zealand New Zealand time use survey - user's guide. Ministry of Women's Affairs, 1999

Stinson, L. L. Measuring how people spend their time: a timeuse survey design. Monthly Labor Review, August 1999, 12-19.

S - Plus 4 Guide to Statistics. Data Analysis Products Division, Mathsoft, Seattle, 1998.

Tsirakis, T. Social interaction improves mental and physical well being. Geriatrics Aging [periódico on line] $1999 \mathrm{Set} /$ Oct, 2 (5); Disponivel em <URL:http:/ /www.geriatricsandaging.ca> [Novembro 2001].

Ujimoto, K. V. Time-budget methodology for research on aging. Social Indicators Research, 1990, 23: 381-93.

United Nations (1978) Progress report on the development of statistics of time-use. Report of the Secretary-General to the Twentieth Session of the Statistical Commission 20 February-2 March 1979, (E/CN.3/519)

Umezaki, M., Ishimaru, H. \& Ohtsuka, R. Daily time budgets of long distance commuting workers in Tokyo negalopolis. $\mathbf{J}$ Biosoc Sci, 1999 Jan, 31 (1): 71-80. Disponivel em: <URL:http://www.ncbi. nlm.nih.gov/entrez/ query [Setembro 2001]. 
Van den Homberg, C. E., Schouten, E. G., Van Staveren, W. A ., Van Amelsvoort, L. G. \& Kok, F. J. Physical activities of noninstitucionalized Dutch elderly and characteristics of inactive elderly. Med Sci Sports Exerc., 1995, 23 (3): 334-39.

Verbrugge, L.M., Gruber-Baldini, A .L. \& Fozard, J. L. Age differences and age changes in activities: Baltimore longitudinal study of aging. J Gerontol B Psychol Sci Soc Sci, 1996 Jan, 51 (1): S30-41. Disponivel em: < nlm.nih.gov/entrez/ query [Setembro 2001].

Volz, J. Successful aging: the second 50. Monitor on Psychology, [periódico on line] 2000, 31 (1). Disponivel em: <URL:http://www.apa.org/monitor/jan00/homepage.html>.

[Setembro 2001].

Wahl, H. W. everyday competence: a construct in search for an identity. Z Gerontol Geriatr., 1998, 31 (4): 243-49.

Watson, Y. L., Arfken, C. L. \& Birge, S. J. Clock completion: na objective screening test for demetia. Journal of American Geriatrics Society, 1993, 41 (11): 1235-1240.

Wilkin, D. Dependence. In: Peace, S. M. Researching social gerontology-concepts, methods and issues. London, Sage Publications, 1990, p. 19.

Willis, S. L. Everyday cognitive competence in elderly persons: conceptual issues and empirical findings. The Gerontologist, 1996, 36: 595-601. 
Willis, S. L., Jay, G. M., Diehl, M. \& Marsiske, M. Longitudinal change and prediction of everyday task competence in the elderly. Research on Aging, 1992, 14 (1): 68-91.

Winninger, D. \& Pineau, L. Incapacity and autonomy: striking a balance. Health Law Can, 1995, 15 (3): 59-64.

Woo, J. Relationships among diet, physical activity and other lifestyle factors and debilitating diseases in the elderly. Eur. J Clin Nutr, 2000 Jun, 54 (Suppl 3): S143-47. Disponivel em: <URL:http://www ncbi nlm.nih gov/entrez/ query [Novembro 2001]

(WHO) World Health Organization. International Classification of Impairments, Disabilities and Handicaps. Genebra; 1980 (WHO).

(WHO) World Health Organization. The uses of epidemiology in the study of the elderly. Technical Reports Series 706. Switzerland, 1984.

(WHO) World Health Organization. Growth of the elderly population of the world. In: Health of the Elderly. Technical Report Series 779: 8-31. Genebra, 1989 (WHO).

(WHO) World Health Organization. Ageing and health. A global challenge for the twenty first century. Proceedings of a WHO Symposium, Kobe, Japan; 1999 (WHO). 


\section{ANEXO I - Termo de consentimento para participacão em pesquisa.}

\section{TERMO DE CONSENTIMENTO LIVRE E ESCLARECIDO}

Prezada Senhora,

Solicitamos seu consentimento para participar de uma pesquisa, cujo resultado será utilizado na descrição das atividades diárias de mulheres idosas em função do tempo.

A pesquisa faz parte de um estudo desenvolvido na área de gerontologia, sendo que os resultados serão publicados na literatura especializada.

A mesma consta dos seguintes tópicos:

a) teste de cognição (teste do relógio), cujo resultado poderá indicar alguma informação sobre sua atenção e memória;

b) entrevista individual, realizada em local reservado, onde será relatado todas as atividades realizadas no dia anterior, desde o acordar até o momento de deitar-se;

c) questionário para coleta de dados pessoais.

Esclarecemos que haverá total sigilo quanto à sua identidade e informações pessoais, que sua participação é totalmente voluntária, com plena liberdade para negar este consentimento se assim o desejar e sem custo algum.

Declaro que estou ciente dos termos deste consentimento e autorizo a publicação dos resultados na literatura especializada. 
ANEXO II - Clock Completion Test.

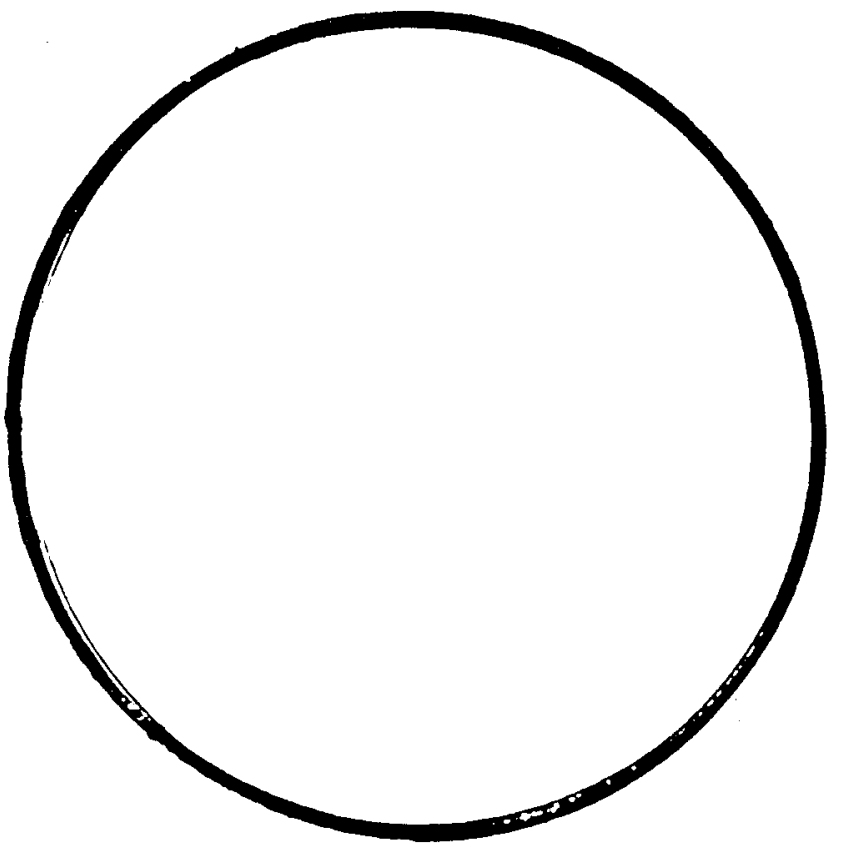

In: WATSON, Y. I., ARFKEN, C. L. \& BIRGE, S. B. Clock completion: an objective screening test for dementia. Journal of American Geriatrics Society, 1993, v. 41, n. 11, p. 1235-1240. 


\section{ANEXO III - Resultados do Clock Completion Test.}
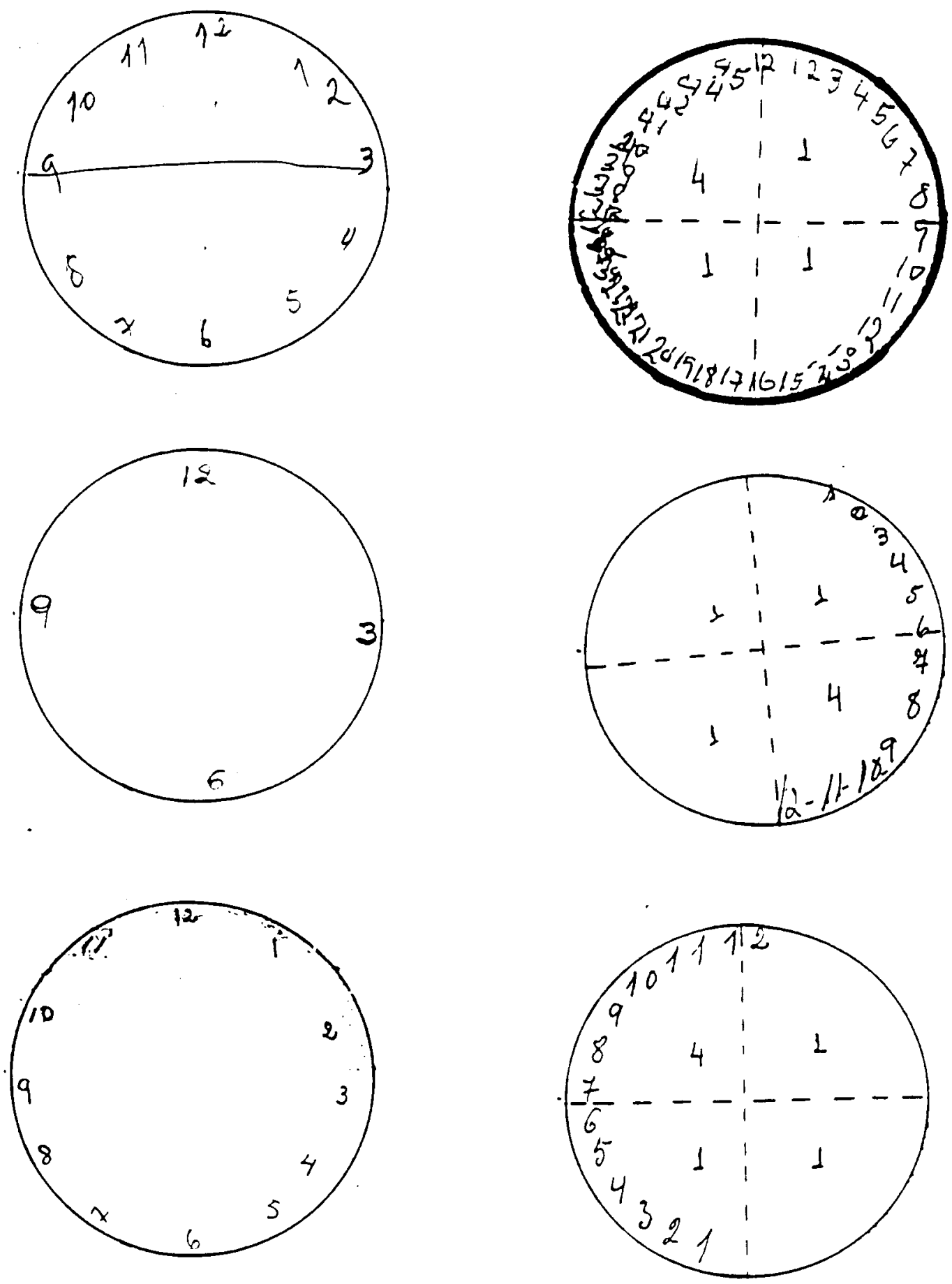

Á esquerda, escores normais. À direita, para exemplificação, escores anormais 
ANEXO IV - Folha de registro de dados pessoais.

Data............... Dia da semana:

I - DADOS DE IDENTIFICAÇÃO

1 - Nome:

2 - Idade:

3 - Estado civil:

III - INSTRUÇÃO

1 - Qual a última série que freqüentou na escola?

IV - OCUPAÇÃO

1 - Qual a sua ocupação hoje?.

2 - Qual era a sua ocupação anterior?

3 - A Sra. recebe algum tipo de benefício? Qual?

V - MORADIA

1 - Com quem o Sra. mora?

2 - Quantas pessoas moram na casa com o Sra.?

3 - Sua casa é: própria, alugada, cedida, outras

\section{VI - SITUAÇÃO ECONÔMICA}

1 - A Sra. é independente economicamente?

2 - A Sra. recebe ajuda financeira? De que tipo?

2 - A Sra. recebe até quantos salários mínimos por mês?. 
ANEXO V - Time Diary.

Exhibit 2. An example of a time diary used by the Austrailian Bureau of Statistics

Day 1

6 a.m. 9 a.m.

\begin{tabular}{|c|c|c|c|c|c|}
\hline & 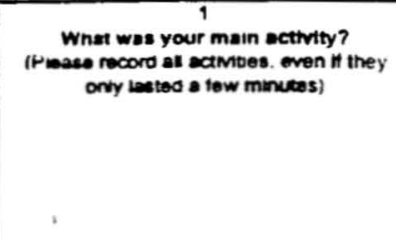 & 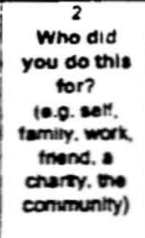 & 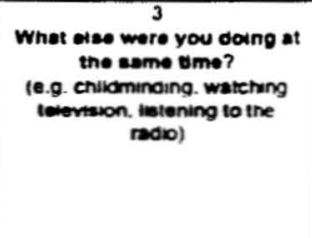 & $\begin{array}{l}\text { where wore } \\
\text { you? } \\
\text { (e g. ot work, } \\
\text { nome. on a } \\
\text { bue anming a } \\
\text { car) }\end{array}$ & 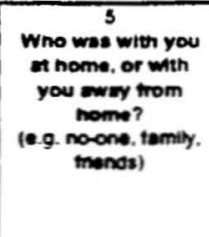 \\
\hline .05 & Sieep & Self & Passive child care & Home & Family \\
\hline .10 & 1 & & 1 & -1 & \\
\hline .15 & $\downarrow$ & & & & \\
\hline .20 & Tolet & & & & \\
\hline .25 & Had shower & & & & \\
\hline .30 & $\checkmark$ & & & & \\
\hline .35 & Got aressed & 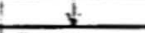 & & & \\
\hline .40 & Put on a load of washing & Family & $\downarrow$ & & \\
\hline .45 & Made breakfas! & 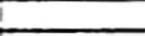 & Talked to family & & \\
\hline .50 & 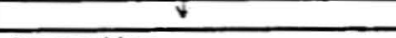 & & $\downarrow$ & & \\
\hline .55 & Ate breaktast & Self & Read newspaper & & \\
\hline 7:00 & 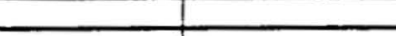 & 1 & 1 & & \\
\hline .05 & $\downarrow$ & $\downarrow$ & $\downarrow$ & & \\
\hline .10 & Hung washing on line & Family & Nothing & & \\
\hline .15 & $\downarrow$ & $\boldsymbol{w}$ & $x$ & & \\
\hline .20 & Dressed childoren & Chiloren & Talked to children & & \\
\hline .25 & $\downarrow$ & $x$ & $x$ & $I$ & \\
\hline .30 & Erushed hair, teeth, etc. & Self & Nothing & I & \\
\hline .35 & 1 & 1 & 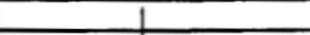 & & \\
\hline .40 & $\downarrow$ & $x$ & $\downarrow$ & 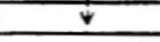 & $\nabla$ \\
\hline .45 & Packed chilcren s bags & Chiloren & Said goodbye to partner & & \\
\hline .50 & Drove children to my & 1 & Talked to children & Drving car & 2 children \\
\hline .55 & mother s house & I & 1 & 1 & 1 \\
\hline 8:00 & 1 & 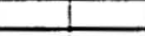 & I & I & 1 \\
\hline .05 & $\downarrow$ & $\downarrow$ & $\downarrow$ & $\downarrow$ & $\downarrow$ \\
\hline .10 & Greated my mother & Self & Organising children & Mothers & Children 8 \\
\hline .15 & Said ooodbve to childaren & 1 & Nothing & $\dot{i}$ & mother \\
\hline .20 & Drove to work & I & Lustenina to radio & Car & No-one \\
\hline .25 & & $i$ & & & 1 \\
\hline .30 & $\sqrt{2}$ & 1 & t & $\downarrow$ & \\
\hline .35 & Parked car \& walked to work & $\checkmark$ & Nothing & Sreet & $\downarrow$ \\
\hline .40 & Working & Work & & Work & Workmates \\
\hline .45 & i & 1 & & 1 & 1 \\
\hline .50 & $\perp$ & $!$ & & I & 1 \\
\hline .55 & $i$ & 1 & & L & I \\
\hline 9:00 & 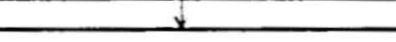 & 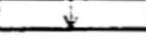 & 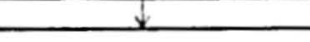 & ע. & $\psi$ \\
\hline
\end{tabular}

SOURCE: Australian Bureau of Statistics. Trme Use Survey Austratia User s Guide. 1992. ABS

Catalogue No. 4150.0 (Canberra. Commonwealth Government Prnter).

Australian Bureau of Statistics, 1992. In: STINSON, L. L. Measuring how people spend their time: a time-use survey design. Montly Labor Review, August 1999, 12-19. 


\section{ANEXO VI - Time diary (português).}

NOME:.............

Data da entrevista:. $19 \ldots / .04 .102$

Data nascimento:02,04/30 Acordou: 06.30 .hs

Dia da semana recordado: 42 feuth
Deitou-se10:00.hs.

\begin{tabular}{|c|c|c|c|c|c|}
\hline hora & Atividade principal & Para quem? & $\begin{array}{l}\text { O que mais fazia } \\
\text { ao mesmo tempo? }\end{array}$ & $\begin{array}{l}\text { Onde vc } \\
\text { estava? }\end{array}$ & $\begin{array}{c}\text { Quem estava } \\
\text { com vc? }\end{array}$ \\
\hline \multicolumn{6}{|c|}{ 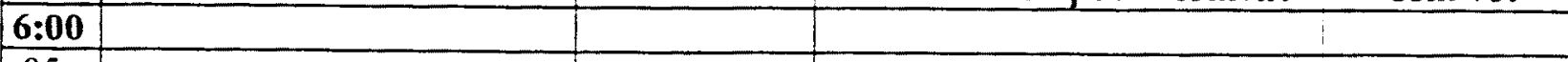 } \\
\hline \multicolumn{6}{|l|}{.05} \\
\hline \multicolumn{6}{|l|}{.10} \\
\hline \multicolumn{6}{|l|}{.15} \\
\hline .20 & & & $!$ & & \\
\hline \multicolumn{6}{|l|}{.25} \\
\hline .30 & tconcar & & $=$ & Casia & mande \\
\hline .35 & hoacles & 2154 & & $1(1)$ & $1(3)$ \\
\hline .40 & it & $\frac{1}{2}$ & & & \\
\hline .45 & tratar vassaved (4) & - & & & \\
\hline .50 & L & ) & 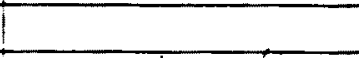 & & \\
\hline .55 & Pupanar café (4) & fam tua & auvićch & $T$ & \\
\hline $7: 00$ & $t$ & 11 & $1 \quad(3)$ & 1 & \\
\hline .05 & tomar wafe (1) & & & 1 & \\
\hline .10 & $L, 1$ & $\uplus$ & $\downarrow$ & 1 & \\
\hline 15 & Opincion tmeletan(1) & p/s & $=$ & 1 & \\
\hline 20 & 1 & 1 & 1 & 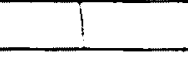 & 1 \\
\hline 25 & & & 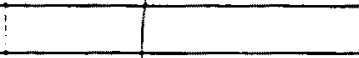 & & $\vdots$ \\
\hline 30 & 1 & & 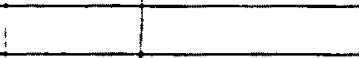 & : & 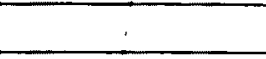 \\
\hline 35 & $\frac{1}{4}$ & + & $\downarrow$ & & 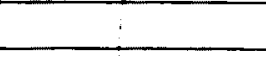 \\
\hline 40 & arue men guacto (4) & Lamila & cemoversar of & 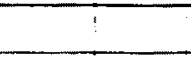 & 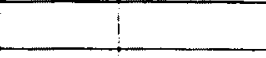 \\
\hline 45 & 1 & 1 & mando & $\vdots$ & 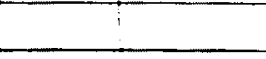 \\
\hline .50 & & 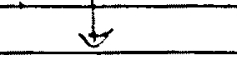 & $1 \quad(4)$ & 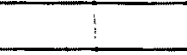 & \\
\hline .55 & $\operatorname{lintax}-x$ & si & $t$ & 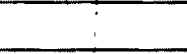 & . \\
\hline 8:00 & ${ }_{-1}$ & 1 & 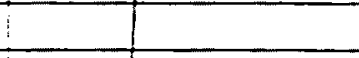 & $i$ & \\
\hline .05 & & $t$ & 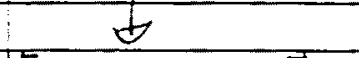 & $\nabla$ &,$\infty$ \\
\hline .10 & it ui supermencodo & Familua & [cominhas] & Run & SE \\
\hline 15 & $1 \quad(4)$ & & 1 & $\sin p(3)$ & 1 \\
\hline .20 & t & & 1 & 12 & 1 \\
\hline .25 & & & 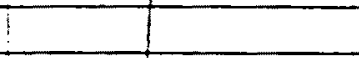 & & \\
\hline .30 & Piton un & & $\Phi$ & 5 & $t$ \\
\hline .35 & Pagnula & jamente & Quntrok rodu & casce & mande \\
\hline .40 & $10 \quad(4)$ & 11 & $1 \quad 13$ & (1) & 13 \\
\hline 45 & 1 & 1 & (2) & & \\
\hline .50 & & & 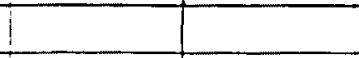 & & \\
\hline .55 & & & 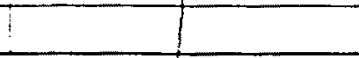 & & 1 \\
\hline 9:00 & 5 & $\Phi$ & $i$ & $z$ & \pm \\
\hline
\end{tabular}


ANEXO Vll - Classificacão das Atividade de lso do Tempo (Time Use Activity Classification).

\section{TIME USE ACTIVITY CLASSIFICATION}

\section{No activity}

00 No activity

001 No recorded activity between episodes

002 No further recorded activity

003 Uncodeable activity

\section{Personal care activities}

\section{Sleeping}

111 Sleeping

112 Nap

12 Sleeplessness

121 Sleoplessness

13 Personal hygiene

131 Personal hygiene

14 Health care

141 Personal medical care

142 Rest because of illness

143 Health treatments

149 Health care nec

15 Eating/drinking

151 Eating meal

152 Eating snack

153 Drinking non alcoholic beverages

159 Eating/drinking nec

17 Associated communication 171 Associated communication

18 Associated travel

181 Associated travel

19 Personal care activities nec

199 Personal care activities nec

\section{Employment related activities}

21 Main job

211 Main job - usual hours - at work

212 Main job - extra hours- overtime

213 Main job - extra hours - work brought home

219 Main job nec

22 Other job

221 Other job - usual hours - at work

222 Other job - extra hours - overtime 
223 Other job - extra hours - work brought home

229 Other job nec

23 Unpaid work in family business or farm

231 Unpaid work in family business or farm

24 Work breaks

241 Work breaks

25 Job Search

251 Job Search

27 Associated communication

271 Associated communication

28 Associated travel

281 Associated travel

29 Employment related activities nec

299 Employment related activities nec

\section{Education activities}

31 Attendance at educational courses (excl. job related training)

311 Attendance at educational courses (excl. job related training)

32 Job related training

321 Job related training

33 Homework/study/research

331 Homework/study/research

34 Breaks at place of education

341 Breaks at place of education

37 Associated communication

371 Associated communication

38 Associated travel

381 Associated travel

39 Education activities nec

399 Education activities nec

\section{Domestic activities}

41 Food \& drink prep/cleanup

411 Food, drink prep/ service

412 Preserving/ireezing

413 Wine/beer making

414 Setclear table

415 Cleanup after food prep/meals

419 Food \& drink prep/cleanup nec

42 Laundry and clothes care

421 Washing, loading/unloading washing machine 
422 Hanging out bringing in washing

423 Ironing

424 Sorting, folding

425 Clothes upkeep/care

426 Clothes making

427 Sorting clothes for disposal

429 Laundry and clothes care nec

43 Other housework

431 Dry housework

432 Wet housework

433 Occasional dry housework

434 Occasional wet housework

439 Oiner housework nec

44 Grounds/animal care

441 Gardening

442 Lawn care

443 Harvesting home produce

444 Cleaning grounds, garage etc

445 Pool care

446 Pet, animal care

449 Grounds/animal care nec

45 Home maintenance

451 Home/equipment repairs

452 Designing new home or interior design

453 Home improvements

454 Making furniture/hhold goods

455 Making furnishings

456 Heat/water/power upkeep

457 Car/boat/bike care

459 Home maintenance nec

46 Household management

461 Paperwork, bilis

462 Budgeting, organising rosters/making lists

463 Selling/disposing of hhold assets

464 Recycling

465 Mail organisation

466 Packing for journey/moving

467 Packing away goods

468 Disposing of rubbish

469 Household management nec

47 Associated communication

471 Associated communication

48 Associated travel

481 Associated travel

49 Domestic activities nec

499 Domestic activities nec 


\section{Child Care Activities}

51 Care of children

511 Physical care of children

512 Emotional care of children

52 Teaching/helping/reprimanding

521 Teaching/helping/reprimanding

53 Playing/reading/talking with child 531 'Playing/reading/talking with child

54 Minding child

541 Minding child

55 Visiting child care estab/school

551 Visiting child care estab/school

57 Associated communication

571 Associated communication

58 Associated travel

581 Associated travel

59 Care of children nec

599 Care of children nec

\section{Purchasing goods and services}

61 Purchasing goods

611 Purchasing consumer goods

612 Purchasing durable goods

613 Window shopping

619 Purchasing goods nec

62 Purchasing services

621 Purchasing repair services

622 Purchasing administrative services

623 Purchasing personal care services

624 Purchasing medical care services

625 Purchasing childcare services

626 Purchasing domestic/garden services

629 Purchasing services nec

67 Associated communication

671 Associated communication

68 Associated travel

681 Associated travel

69 Purchasing goods and services nec

699 Purchasing goods and services nec 


\section{Voluntary work and care activities}

71 Caring for adults

711 Caring for adults- physical care

712 Caring for adults - emotional support

72 Helping /doing favours

721 Helping/doing favours

73 Unpaid voluntary work

731 Unpaid voluntary work

77 Associated communication

771 Associated communication

78 Associated travel

781 Associated travel

79 Voluntary work and care nec

799 Voluntary work and care nec

\section{Social and Community interaction \\ 81 Socialising \\ 811 Socialising}

82 Entertainment

821 Attendance at movies/cinema

822 Attendance at concert

823 Attendance at theatre

824 Attendance at library

825 Attendance at museum/ exhibition/ art gallery

826 Attendance at zoo/ animal park/botanic garden

827 Attendance at amusement park

828 Attendance at other mass events

829 Entertainment nec

83 Attendance at sports event

831 Attendance at sports match

832 Attendance at racing event

839 Attendance at sports event nec

84 Religious activities/ ritual ceremonies

841 Religious practice

842 Weddings. funerals, rites of passage

849 Religious activities/ritual ceremonies nec

85 Community participation

851 Attendance at meetings

852 Civic ceremonies

853 Civic obligations

854 Filling in Tıme Use form

859 Community participation nec

87 Associated communication

871 Associated communication 
88 Associated travel

881 Associated travel

89 Social participation nec

899 Social participation nec

\section{Recreation and Leisure}

90 Recreation and leisure

91 Sport and outdoor activity

911 Organised sport

912 Informal sport

913 Exercise (excl walking)

914 Walking (inc for exercise)

915 Hiking/bushwalking

916 Fishing

917 Holiday travel, driving for pleasure

919 Sport and outdoor activity nec

\section{Games/hobbies/arts/crafts}

921 Card, paper, board games/crosswords

922 Games of chance/gambling

923 Home computer games/computing as hobby

924 Arcade games

925 Hobbies,collections

926 Handwork, crafts

927 Ants

928 Performing/making music

929 Games/hobbies/arts/cratts nec

\section{Reading}

931 Reading book

932 Reading magazine

933 Reading newspaper

934 Reading CD rom

939 Reading nec

94 Audio/visual media

941 TV watching/listening

942 Video watching

943 Listening to radio

944 Listening to records/tapes/CDs

945 Accessing internet

949 Audio/visual media nec

95 Attendance at courses (excl school and university)

951 Attendance at personal development courses

952 Attendance at DIY courses

953 Attendance at art/craft/hobby courses

959 Attendance at courses nec (excl school and university)

96 Other free time

961 Relaxing, resting

962 Doing nothing

963 Thinking

964 Worrying 


\section{Time Use Activity Classification - 1997}

965 Drinking alcohol/social drinking

966 Smoking

967 Interacting with pets/walking dog

968 Enjoying memorabilia

969 Other free time nec

97 Associated communication

971 Associated communication (in person when sec)

972 Associated communication (by telephone when sec)

973 Associated communication (written when sec)

974 Associated communication (by PC when sec)

98 Associated travel

981 Associated travel

99 Leisure and recreation nec

999 Leisure and recreation nec 


\section{SOCIAL CONTEXT}

There are 5 social context codes which describe the interactions occurring in a household or elsewhere. The different social context codes can be put together to more fully describe the interactions. All codes refer to the others present and do not include the respondent. These are needed to identify:

the presence of family within and outside the household the presence of other interacting persons of varying degrees of closeness the presence of persons for whom care and support is given

\section{Field 1: Family relationship (Social context A - SCA)}

1 Spouse only

2 Other family (excluding spouse)

3 Family inc. spouse

4 Family (spouse n/a - lone parent)

5 No-one

9 Undescribed

\section{Field 2: Other relationship (Social context B - SCB)}

0 Not applicable/no-one

1 Friends - adult

2 Colleagues/neighbours/acquaintances

3 Friends and colleagues etc.

4 Children of friends/neighbours/acquaintances/colleagues (without adults)

5 Shop/service personnel

6 Crowd/ other people not acquainted

9 Undescribed

Field 3: Household status (Social context C - SCC)

0 No household member present

1 In household only

2 Ex household only

3 In and ex household

9 Undescribed

Field 4: Age Structure of other persons in household (Social context D - SCD)

0 No household member present

1 Chlldren 0-11 only or children so described

2 People 60 years and older only

3 People 12.59 only or of unidentified age

4 Children $0-11$ and people 60 years and older only

5. Children 0-11 and people 12-59 only

6. People $12-59$ and 60 years and older

7. All ages

9 Undescribed

Field 5: Health Status of other persons in household (Social context E - SCE)

0 Nohousehold member present

1 Well, able

2 Person with disability, frail aged

3 Person with a short term illness

4. Well and disabled

5. Well and short-term iliness

6. Well, disabled and short-term iliness

7. Disabled and short-term illness

9. Undescribed

The above social context codes are derived using information coded from the "with whom" column of 


\section{Time Use Activity Classification - 1997}

the diary. Information from the "for whom' column is initially coded in 3 fields. Multiple responses can be made in these fields so that the information is fully described.

Fleld 1: People present (wwr -wlth who relationship)

0. Undescribed

1. Spouse

2. Other family (excl spouse) living in household

3. Family living outside household

4. Friends/neighbours/acquaintances

5. Children of friends/neighbours

6. Colleagues

7. Shop personnel/service providers

8. Crowd

9. No-one

10. Non-family household members

Field 2: Health status (hs)

This is the health status of people other than the respondent. Zero should be coded when no-one else is present.

0 . Undescribed/not applicable

1. Well

2. Person with a disability

3. Person with a short term illness

Field 3: Age structure (wwa - with whom age)

This describes the age structure of people present in the household only. Zero should be coded when no-one else is present.

0 . Undescribed/ not applicable

1. Children 0-4

2. Children 5-11

3. Children 12-14

4. Adults $15-59$

5. Adults $60+$ 


\section{FOR WHOM}

The proposed for whom categories are:

00 Undescribed/ not specified

01 Self

02 Children

03 Family - own household-well

04 Family - other household- well

05 Family - other household- sick, frail, disabled

06 Pet

07 Group household - well

08 Group household - sick, frail, disabled

09 Friend/ neighbour - well

10 Friend/neighbour - sick, frail, disabled

11 Work

12 Community - sports

13 Community - arts

14 Community health and welfare

15 Community education/youth

16 Community religious

17 Community emergency services

18 Community other

19 Other person/group nec

\section{LOCATION}

Two fields are used to classify the location.

Field 1: Physical Location

0 Undescribed/ not specified

1 Own house

2 Someone else's house

3 Workplace if outside home (includes farm)

4 Public area e.g. street, town hall, public gardens, church

5 Commercial and service area e.g. bank, shop, office (other than $6 \& 7$ )

6 Establishment for leisure, culture, sport activities

7 Eating and drinking locale (exc. work canteen etc.)

8 Educational establishment

9 Country, bush, beach

Field 2 Spatial location

0 Undescribed/moving between indoors and outdoors

1 Indoor

2 Outdoor

3 in transit

4 Waiting - indoors

5 Waiting - outdoors 


\section{Time Use Activity Classification - 1997}

\section{TECHNOLOGY}

The following technology codes can be used to differentiate between the various communication methods.

0 Undescribed

1 In person

2 Mobile phone

3 Fixed phone

4 Written

5 Fax

6 Personal computer

\section{MODE OF TRANSPORT}

00 Not applicable

01 Train

02 Bus

03 Ferry/tram

04 Taxi

05 Car, van, truck as driver

$06 \mathrm{Car}$, van, truck as passenger

07 Motor bike, scooter

08 Bicycle

09 Walking

98 Transport used, not specified

99 Other nec

In: AUSTRALIAN BUREAU OF STATISTICS Time use survey, Australia. Confidentialist unit record file (information paper) Canberra. 1999 (ABS Catalogue $n^{\circ}+15.01$ 


\section{ANEXO VIII - Fluxograma das atividades dos grupos principais.}

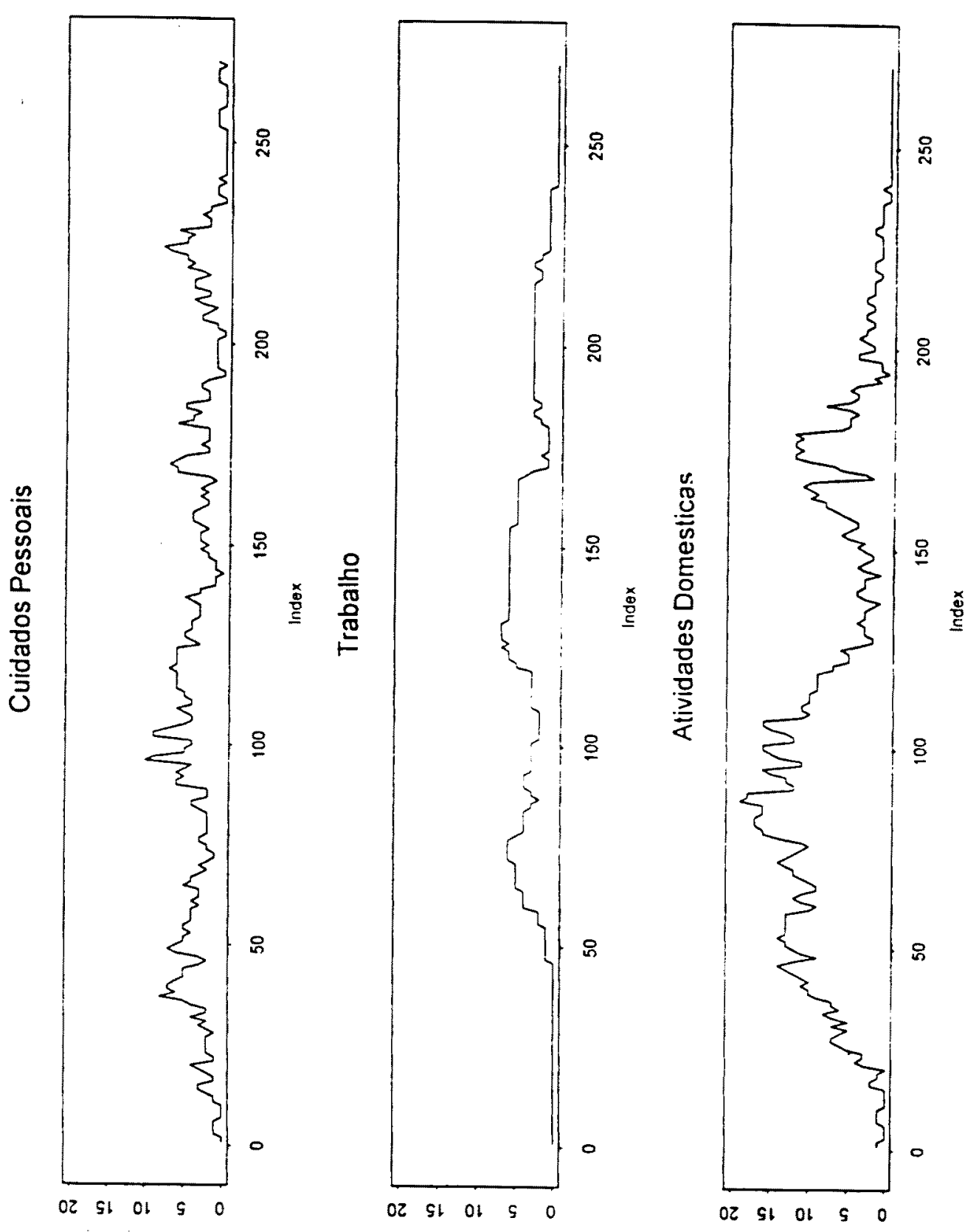




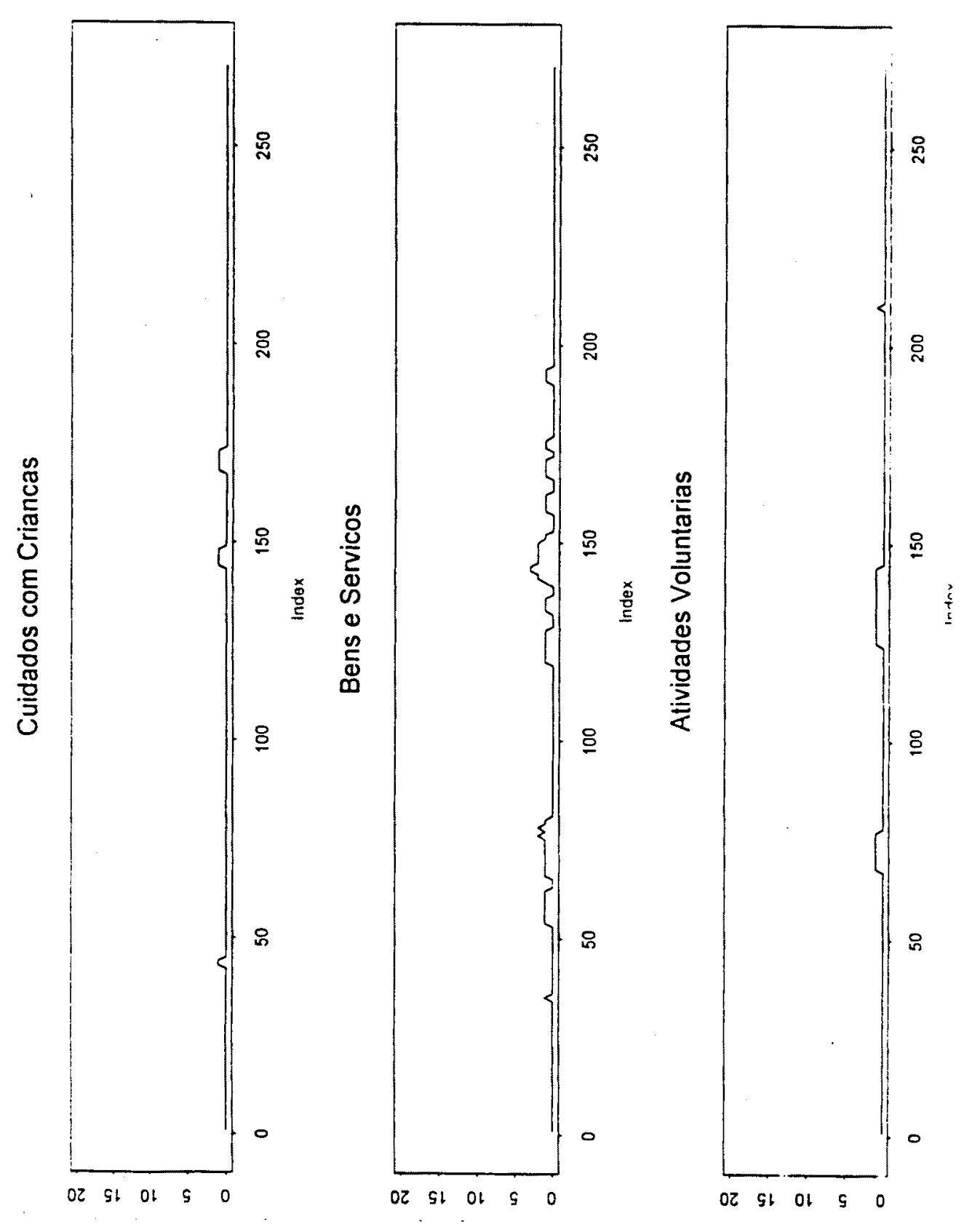




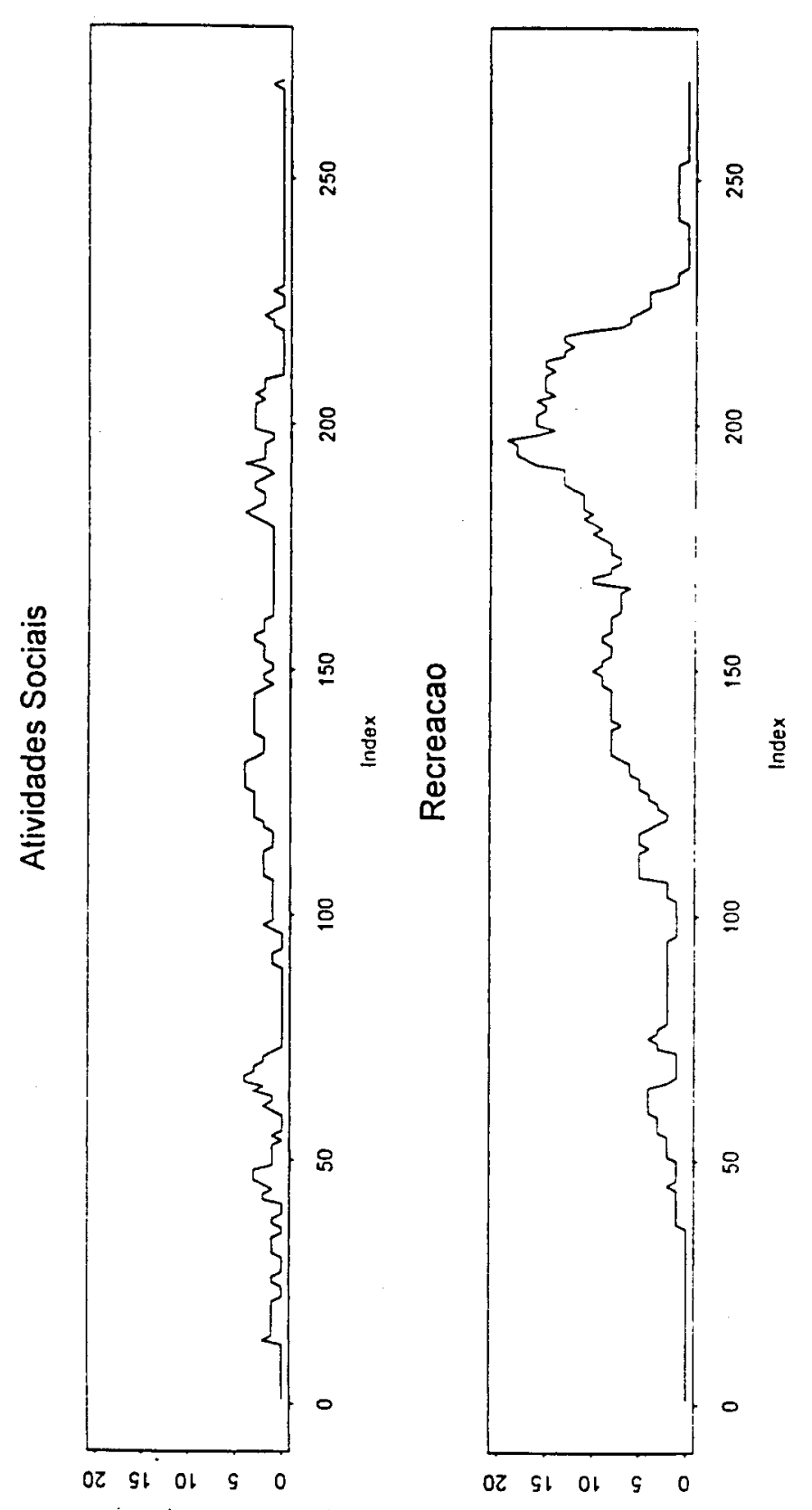


ANEXO IX - Parecer da Comissão de Ética e Pesquisa.

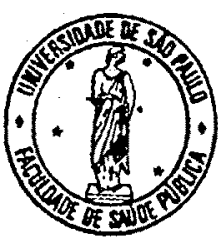

\section{Universidade de São Paulo}

Faculdade de Saúde Pública

COMITÊ DE ÉTICA EM PESQUISA - COEP

Av. Dr. Arnaldo, 715 - CEP 01246-904 - São Paulo - Brasil

Telcfones: (55-11) 3066-7779 - fonc/fax (55-11) 3064 -7314 - c-mail: mdgracas(àusp.br

\section{Of.COEP/38/02}

São Paulo, 19 de fevereiro de 2002

Pelo presente, informo que o Comitê de Ética em Pesquisa da Faculdade de Saúde Pública da Universidade de São Paulo -COEP em sua 01. ${ }^{2} / 02$, Sessão Ordinária, realizada em 19.02.02, analisou e aprovou, de acordo com os requisitos da Resolução 196/96, o Protocolo de Pesquisa n. ${ }^{\circ}$ 634, intitulado: “A ESTRUTURA DO TEMPO E DO FAZER DIÁRIO DE MULHERES IDOSOS”, apresentado pela pesquisadora Leonice Aparecida Doimo.

Atenciosamente,

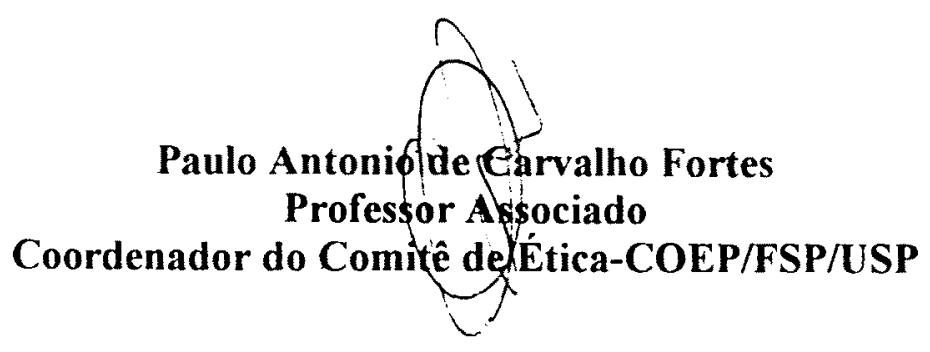

